\title{
USO DE LEITE RECONSTITUIIDO NA FABRICAÇÃO DE QUEIJO MUSSARELA
}

\author{
LEILA MARIA SPADOTI \\ Engenheira Agrônoma
}

Orientador: Prof. Dr. ANTONIO JOAQUIM DE OLIVEIRA

Dissertação apresentada à Escola Superior de Agricultura "Luiz de Queiroz", Universidade de São Paulo, para obtenção do título de Mestre em Ciências, Área de Concentração: Ciência e Tecnologia de Alimentos.

\section{PIRACICABA}

Estado de São Paulo

Agosto-1998 


\section{ERRATA}

\begin{tabular}{|c|c|c|c|c|}
\hline Página & Parágrafo & Linha & onde se lê: & leia-se: \\
\hline 16 & $3^{\circ}$ & $1^{\mathrm{a}}$ & acumulo & acúmulo \\
\hline 16 & $5^{\circ}$ & $3^{\mathbf{a}}$ & enzimático & enzímico \\
\hline 21 & $3^{0}$ & $5^{\mathrm{a}}$ & hidroclórico & clorídrico \\
\hline 23 & $2^{\mathbf{0}}$ & $1^{\underline{a}}$ & hidroliza & hidrolisa \\
\hline 28 & $2^{\mathbf{o}}$ & $2^{\mathrm{a}}$ & estrato & extrato \\
\hline 70 & $4^{\underline{0}}$ & $3^{\mathrm{a}}$ & $\begin{array}{l}\text { compacta s sua } \\
\text { estrutura }\end{array}$ & $\begin{array}{l}\text { compacta a sua } \\
\text { estrutura }\end{array}$ \\
\hline
\end{tabular}


Dados Internacionais de Catalogação na Publicação (CIP) DIVISÃo DE BIBLIOTECA E DOCUMENTAÇÃO - Campus "Luiz de Queiroz"/USP

Sapadoti, Leila Maria

Uso de leite reconstituído na fabricação de queijo mussarela / Leila Maria Spadoti. - - Piracicaba, 1998.

101 p. : il.

Dissertaçāo (mestrado) - Escola Superior de Agricultura Luiz de Queiroz, 1998.

Bibliografia.

1. Laticinio 2. Leite reconstituido 3. Queijo mussarela 4. Tecnologia de alimento I. Título

CDD 637.353 
Aos meus pais

João Moacyr e Adelina

DEDICO

As minhas irmãs

Rosana, Célia e

Dorotéia

OFEREÇO 


\section{AGRADECIMENTOS}

À Deus, fonte de toda a energia que criou e que mantém o Universo.

À Escola Superior de Agricultura "Luiz de Queiroz", em especial ao Departamento de Ciência e Tecnologia Agroindustrial, seus professores e funcionários, pelos ensinamentos e pelo auxílio na realização deste trabalho.

Ao Prof. Antonio Joaquim de Oliveira, pelo carinho, apoio e orientação na elaboração deste trabalho.

Ao Prof. Múcio Mansur Furtado, pela amizade, ensinamentos e colaboração durante a execução deste trabalho.

À Luciana Viriato Saboya, pela amizade, incentivo e explicações das análises laboratoriais.

À Cleomar Maria de Carvalho, pelo enorme carinho, amizade e auxílio nas análises laboratoriais.

Ao Prof. Luiz Eduardo Gutierrez, pela amizade e colaboração em várias etapas deste trabalho.

Ao Prof. Jorge Horii e a secretária da pós-graduação Regina L.M. Lourenço, pelo carinho e auxílio na resolução de questões referentes ao mestrado.

Às bibliotecárias Beatriz H. Giongo e Midian Gustinelli, pela amizade e auxílio na parte de referências bibilográficas.
À Sônia Piedade, pelas explicações referentes à análise estatística dos dados deste experimento. 
Ao meu primo André Luís Spadoti, pelo apoio e valiosa colaboração na parte de digitação desta tese.

A todos os meus amigos da ESALQ, em especial Carlos Eduardo Garcia, Ingrid Garboggini, Valmir Alcarde, Viviane S. Monteiro, Rudimar Cherubim, Francisco Nascimento, Nazareno Travaglini Jr., Fabiana Bruzantin, Fátima Ribeiro, Marta V. Bernardi.

Aos meus familiares e amigos, pelo carinho e incentivo, em especial Márcio, Ivanjo, Luiz Jacob, Maria, Cristina, Marlene, Raquel, Renata, Vanderléia.

A Coordenadoria de Aperfeiçoamento do Pessoal de Ensino Superior (CAPES), pela concessão da bolsa de estudo. 
A todos que direta ou indiretamente contribuíram para a realização desta tese...

\section{DEUS}

Eu imagino Deus como a fonte de toda a energia que criou e que mantém o Universo.

Eu vejo Deus no sol, na lua e em cada estrela no céu.

Eu vejo Deus na abelha que suga o néctar das flores para produzir o mel, no inseto que devora a abelha,

no pássaro que devora o inseto,

no animal que devora o pássaro,

no homem que devora o animal e

no verme que devora o homem.

Só não consigo ver Deus no homem que devora o homem e é por isso que acho que ainda tenho muito que aprender por esses caminhos da vida.

Autor desconhecido. 


\section{SUMÁRIO}

Página

LISTA DE FIGURAS............................................................................... viii

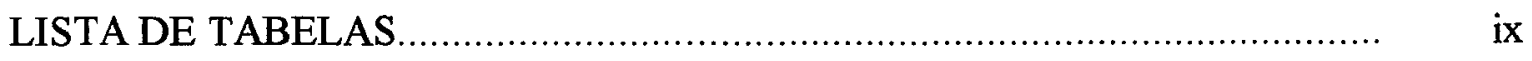

RESUMO

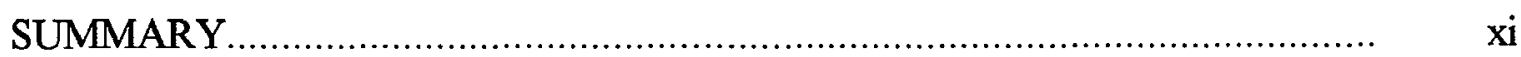

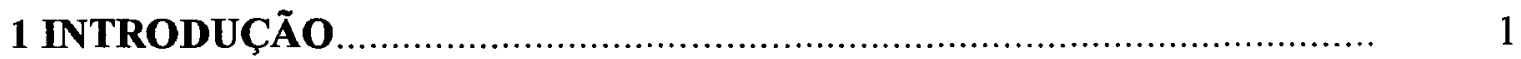

2 REVISÃO DE LITERATURA ......................................................... 3

2.1 Queijos de massa filada................................................................. 3

2.2 Tipos e características do queijo Mussarela................................................ 4

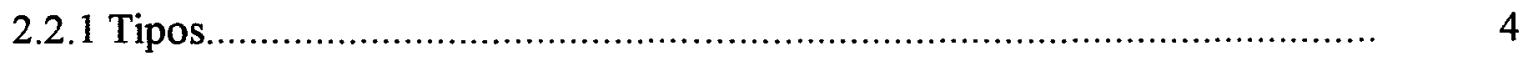

2.2.2 Padrões legais............................................................................ 5

2.2.2.1 Padrões físico-químicos....................................................................... 5

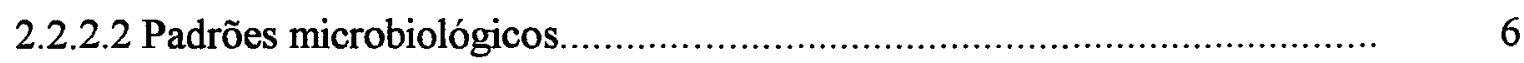

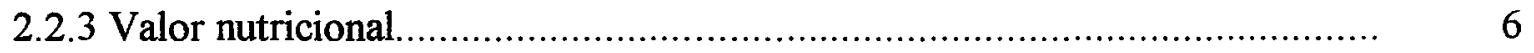

2.3 Propriedades funcionais da Mussarela................................................... 7

2.3.1 Noções gerais sobre proteólise ............................................................ 8

2.3.2 Propriedades da Mussarela não derretida................................................ 11

2.3.3 Propriedades da Mussarela derretida...................................................... 11

2.3.3.1 Derretimento................................................................................. 11

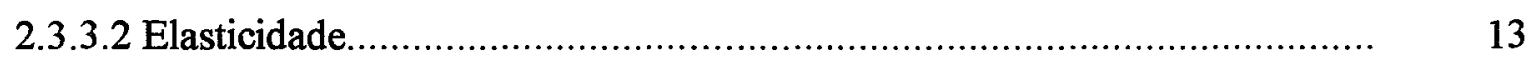

2.3.3.3 Separação de óleo livre .......................................................................

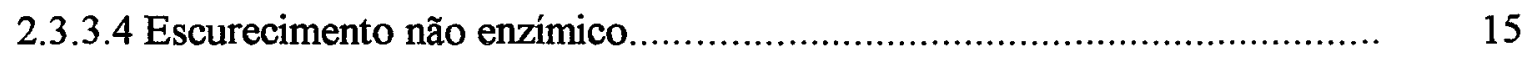

2.4 Etapas da fabricação do queijo Mussarela................................................. 17

2.4.1 Escolha do tipo de leite.................................................................... 19

2.4.2 Pasteurização e padronização do leite........................................................ 19

2.4.3 Fermentação natural biológica e acidificação direta.................................... 20 
2.4.4 Adição de coadjuvantes de processamento................................................ 21

2.4.4.1 Cloreto de cálcio............................................................................. 21

2.4.4.2 Coalho .............................................................................. 22

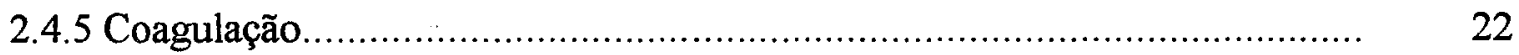

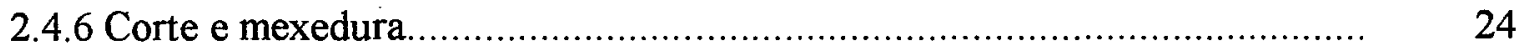

2.4.7 Aquecimento e delactosagem............................................................... 24

2.4.8 Dessoragem e pré-prensagem............................................................... 25

2.4.9 Fermentação da massa......................................................................... 26

2.4.10 Filagem e moldagem.................................................................... 27

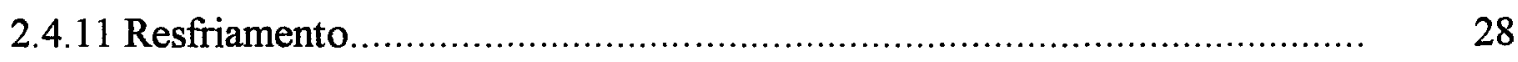

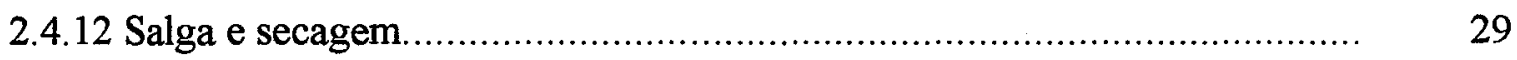

2.4.13 Estabilização e comercialização..................................................... 30

2.5 Rendimento econômico e técnico de queijos............................................. 31

2.6 Uso de leite em pó na fabricação de queijos................................................. 32

2.6.1 Sazonalidade da produção de leite no Brasil.............................................. 32

2.6.2 Efeitos da secagem sobre o leite..................................................... 33

2.6.3 Classificação do leite em pó................................................................. 34

2.6.4 Especificações do leite em pó utilizado na fabricação de queijos................ 35

2.6.5 Queijos produzidos com o uso de leite em pó......................................... 36

2.6.5.1 Tipos diversos..................................................................... 36

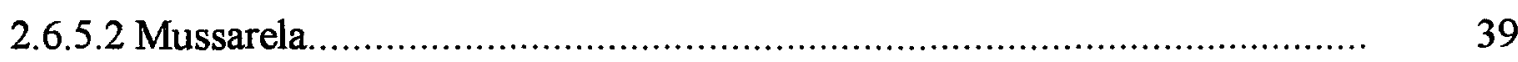

2.6.6 Efeitos da utilização de leite em pó sobre a fabricação de queijos.............. 40

2.6.6.1 Coagulabilidade ........................................................................... 40

2.6.6.2 Sinérese

2.6.6.3 Maturação e desenvolvimento de flavor.............................................. 42

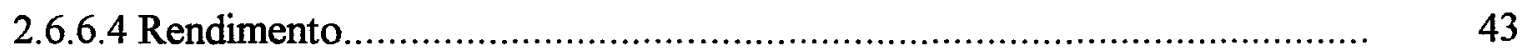

3 MATERIAL E MÉTODOS ................................................................ 45

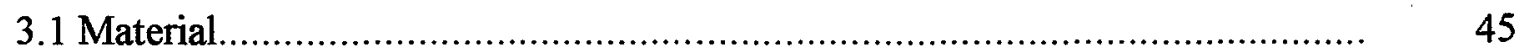

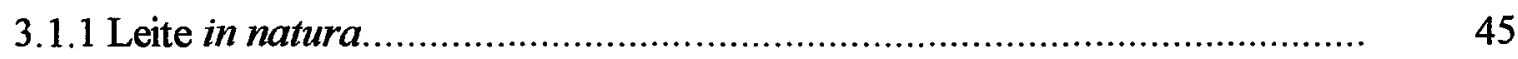




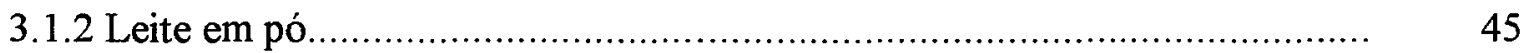

3.1.3 Fermento lático........................................................................... 46

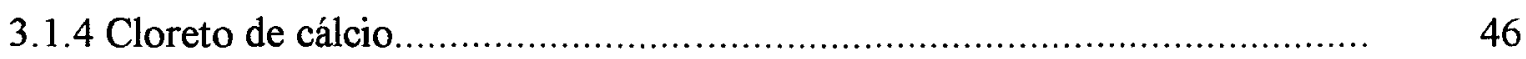

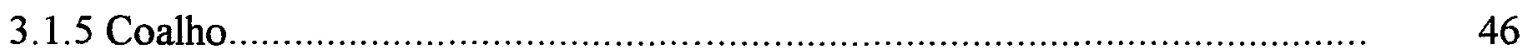

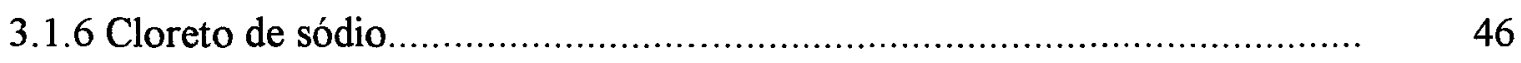

3.2 Métodos................................................................................ 46

3.2.1 Reconstituição do leite em pó................................................................ 46

3.2.2 Fabricação dos queijos......................................................................... 47

3.2.3 Análises fisico-químicas do leite e do soro................................................ 49

3.2.3.1 Densidade .............................................................................. 50

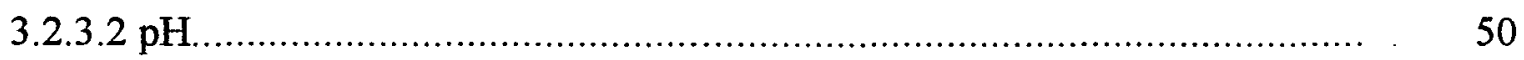

3.2.3.3 Acidez titulável...................................................................... 50

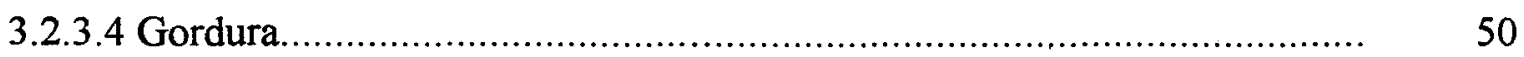

3.2.3.5 Extrato seco total...................................................................... 50

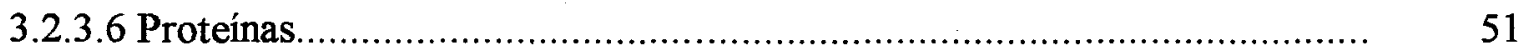

3.2.3.7 Desnaturação das proteínas de soro do leite....................................... 51

3.2.4 Análises físico-químicas do queijo....................................................... 51

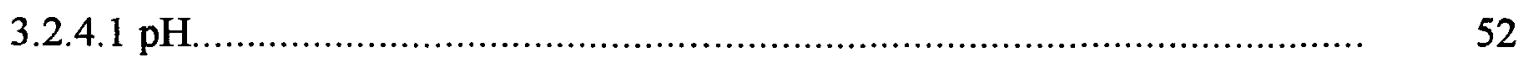

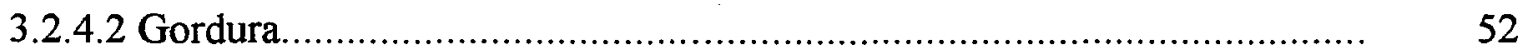

3.2.4.3 Gordura no extrato seco................................................................... 52

3.2.4.4 Umidade.................................................................................. 53

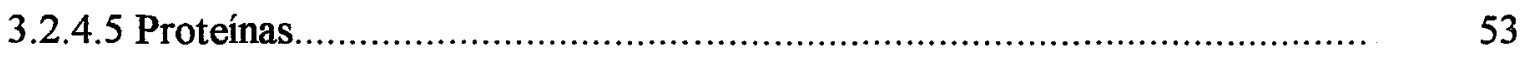

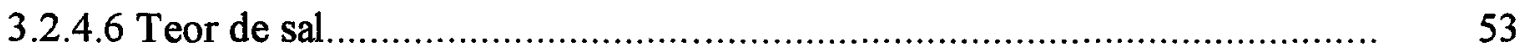

3.2.4.7 Teor de sal na fase aquosa................................................................ 53

3.2.4.8 Atividade de água.................................................................. 54

3.2.5 Cálculos de rendimento econômico e técnico.............................................. 54

3.2.6 Avaliação da propriedade de fatiamento............................................... 55

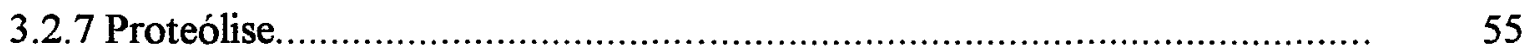

3.2.7.1 Nitrogênio total......................................................................... 56 


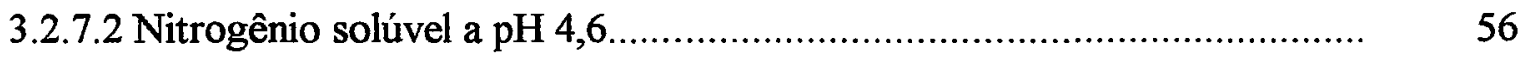

3.2.7.3 Nitrogênio não protéico solúvel em TCA 12\%....................................... 56

3.2.7.4 Índice de extensão da proteólise.......................................................... 57

3.2.7.5 Índice de profundidade da proteólise ..................................................... 57

3.2.8 Propriedades funcionais................................................................... 57

3.2.8.1 Derretimento............................................................................. 5

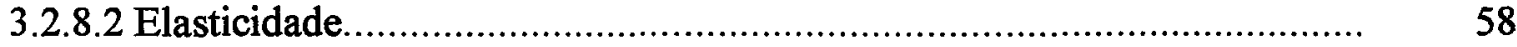

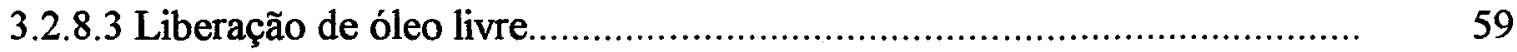

3.2.9 Análise estatística.............................................................................. 59

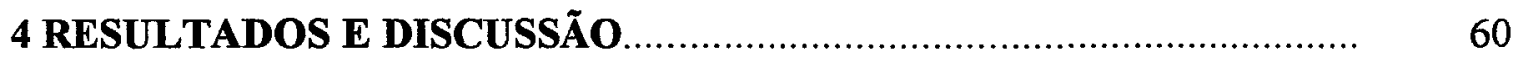

4.1 Composição físico-química do leite.............................................................. 60

4.2 Desnaturação protéica do leite.................................................................. 61

4.3 Pré-maturação do leite............................................................................... 62

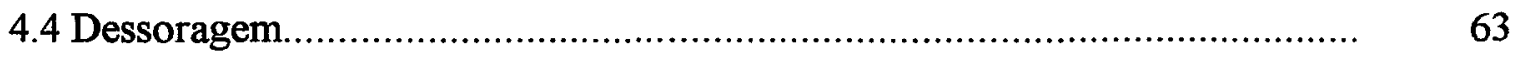

4.5 Composição físico-química do soro............................................................. 64

4.6 Fermentação e filagem da massa ............................................................... 65

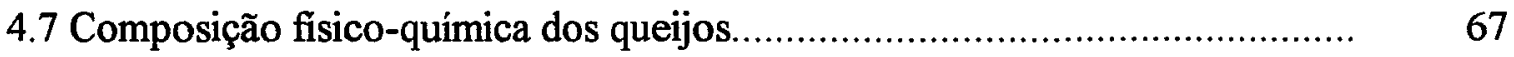

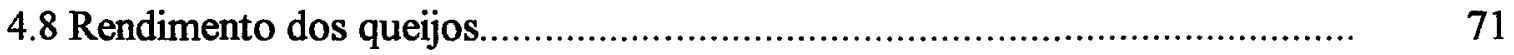

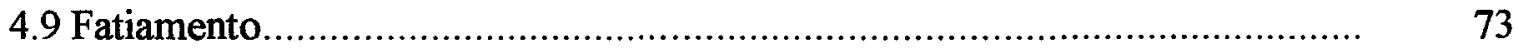

4.10 Avaliação dos queijos durante o período de armazenamento refrigerado...... $\quad 73$

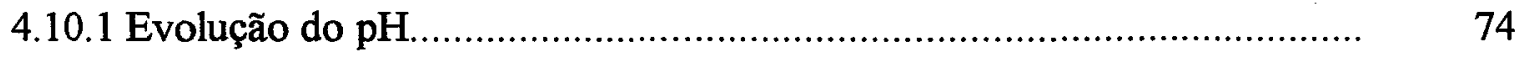

4.10.2 Extensão da proteólise..................................................................... 75

4.10.3 Profundidade da proteólise.................................................................. 76

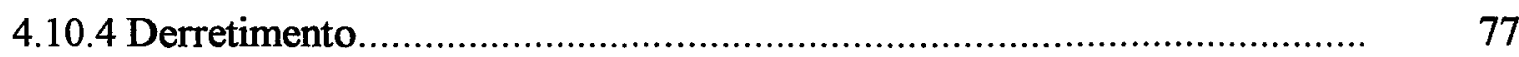

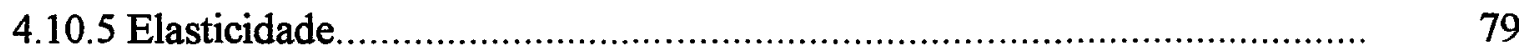

4.10.6 Liberação de óleo livre.................................................................... 80

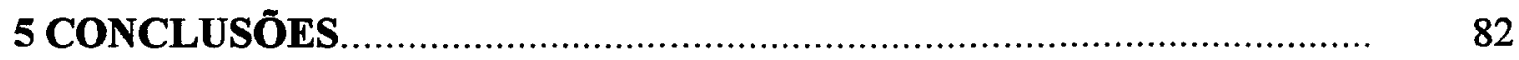

REFERÊNCIAS BIBLIOGRÁFICAS................................................. 83 


\section{LISTA DE FIGURAS}

Página

1 Categorias de Mussarela de acordo com seu teor de umidade e \% de GES........ 4

2 Categorias de Mussarela de acordo com seu teor de umidade e \% de GES........ 5

3 Requisitos microbiológicos para a Mussarela................................................. 6

4 Quadro nutricional do leite pasteurizado e dos 3 principais queijos

consumidos no Brasil por 100 gramas de parte comestível.

5 Modelo se uma submicela de caseína e de uma micela de caseína composta de submicelas e fosfato de cálcio coloidal..........................................

6 Efeito das atuações do coalho, do fermento e da plasmina sobre a caseína........ 9

7 Etapas da produção de queijo Mussarela pelo processo tradicional................... 18

8 Representação das interações entre soroproteínas e caseínas no leite cru e aquecido 34 


\section{LISTA DE TABELAS}

Página

1 Valores médios das características fisico-químicas dos leites empregados na elaboração dos queijos. 60

2 Valores médios da porcentagem de desnaturação das proteínas do soro, dos leites empregados na elaboração dos queijos..

3 Valores médios de $\mathrm{pH}$ inicial do leite, do leite pré-maturado, da massa e do soro na dessoragem, dos 3 tratamentos avaliados

4 Valores médios das características físico-químicas dos soros obtidos na elaboração de queijos com 0,10 e $20 \%$ de leite reconstituído.

5 Valores médios de $\mathrm{pH}$ das massas, dos 3 tratamentos, durante o processo de fermentação

6 Valores médios das características físico-químicas dos queijos, 2 dias após a sua manufatura.

7 Meios de expressão do rendimento dos queijos elaborados com 0, 10 e $20 \%$ de leite reconstituído.

8 Evolução do $\mathrm{pH}$ dos queijos, durante o período de armazenamento refrigerado

9 Extensão da proteólise dos queijos, durante o armazenamento refrigerado.......

10 Profundidade da proteólise dos queijos, durante o armazenamento refrigerado

11 Porcentagens médias de derretimento dos queijos

12 Valores médios, em centímetros, da elasticidade dos queijos derretidos

13 Porcentagens médias do total de gordura dos queijos, dos diferentes tratamentos, presente como óleo livre 


\title{
USO DE LEITE RECONSTITUIDO NA FABRICAÇÃO DE QUEIJO MUSSARELA
}

\author{
Autora: LEILA MARIA SPADOTI \\ Orientador: Prof. Dr. ANTONIO JOAQUIM DE OLIVEIRA
}

\section{RESUMO}

Atualmente, o queijo Mussarela é o queijo de maior produção nacional. Entretanto, devido ao problema de sazonalidade da produção leiteira, durante certo período do ano ocorre uma queda na oferta e uma elevação no preço desse queijo, sendo que o uso de leite reconstituído, misturado ao leite in natura, poderia ser uma alternativa para a estabilização da oferta do produto no mercado. Neste experimento foram elaborados queijos Mussarela com leite in natura e com leite in natura adicionado de 10 e $20 \%$ de leite reconstituído (obtido a partir de leite em pó "média temperatura"). As características físico-químicas, o rendimento e a propriedade de fatiamento, dos queijos fabricados com o uso de leite reconstituído foram comparadas com as dos queijos fabricados apenas com leite in natura. Avaliou-se também as modificações ocorridas nos queijos, durante 22 dias de armazenamento refrigerado, através de índices de proteólise e da determinação do $\mathrm{pH}$ e das propriedades funcionais (derretimento, elasticidade e liberação de óleo livre) dos queijos. Concluiu-se que queijo Mussarela pode ser elaborado com a adição de $10 \%$ de leite reconstituído, ao leite in natura, sem que ocorram diferenças marcantes nos parâmetros avaliados e que o uso de $20 \%$ de leite reconstituído não é recomendado pois prejudica o fatiamento, o derretimento e a elasticidade da Mussarela, embora aumente o seu rendimento. 


\section{USAGE OF RECONSTITUTED MLK FOR}

MOZZARELLA CHEESEMAKING

Author: LEILA MARIA SPADOTI

Adviser: Prof. Dr. ANTONIO JOAQUIM DE OLIVEIRA

\section{SUMMARY}

Nowadays the Mozzarella cheese is the most produced in Brazil. However, due to the problem of the seasonal production of milk, in a certain period of the year there is a shortage of the milk offer and than the cheese price rises. For this reason, the usage of reconstituted dry milk blended with fresh milk could be an alternative for the stabilization of the offer of the product in the market. In this experiment Mozzarella cheeses were produced with fresh milk and with fresh milk added of $10 \%$ and $20 \%$ of reconstituted milk (obtained from medium-heat dried whole milk). The physico-chemical and slicing properties and the yield of the cheeses made with fresh milk and with fresh milk added of reconstituted milk (10\% and $20 \%$ ) were compared. Protein breakdown as well $\mathrm{pH}$ and functional properties of the melted cheese (meltability, stretchability and free oil formation) were evaluated for 22 days of storage at refrigeration temperature. It was concluded that Mozzarella cheese may be produced by adding $10 \%$ of reconstituted milk to the fresh milk without affecting the parameters evaluated and that the addition of $20 \%$ of reconstituted milk is not recommended once it affect the slicing, meltability and stretchability properties of the cheese, but it gives a better yield. 


\section{INTRODUÇÃO}

De acordo com Oliveira (1982), a fabricação de queijos se constitui em um método de transformação de considerável parte dos componentes do leite em um produto de fácil conservação e de menor volume, sendo esse produto um alimento altamente nutritivo. Entretanto, embora o queijo seja uma importante forma de preservar os componentes do leite, é necessário frisar que nem todos os seus componentes são concentrados no queijo. Os componentes hidrossolúveis como a lactose, sais minerais e algumas vitaminas ficam dissolvidos no soro, juntamente com as albuminas $\mathrm{e}$ as globulinas. Dessa forma, o componente do queijo que determina o seu rendimento e o caracteriza é basicamente a caseína, embora a gordura represente, na maioria dos queijos, porcentagem maior ou igual à da proteína.

Vários são os tipos de queijos encontrados no mercado, sendo que ,atualmente, os queijos tipo Mussarela, Minas Frescal e Prato são responsáveis por cerca de $65 \%$ do total de queijos que entra no cardápio do brasileiro. Entre eles, o queijo Mussarela é o que vem apresentando maior índice de crescimento nos últimos anos.

Dados fornecidos pela Associação Brasileira das Indústrias de Queijo$\operatorname{ABIQ}^{1}(1997)$, mostram que a produção de queijo Mussarela que era de 33.331 toneladas em 1983 (20,21\% da produção de lácteos em estabelecimentos, sob inspeção federal) chegou a 61.000 toneladas em 1992 (32,25\% da produção nacional de produtos lácteos), sendo que , segundo estimativas não oficiais, fornecidas por Santos (1997), a produção

\footnotetext{
${ }^{1}$ Correspondência pessoal.
} 
atual de Mussarela está em torno de 90.000 toneladas/ano, o que a torna o queijo de maior produção nacional.

Apesar da produção e consumo brasileiro de produtos lácteos, principalmente Mussarela, estarem aumentando ao longo dos anos, vários problemas limitam esse crescimento, sendo que um deles refere-se a sazonalidade da produção leiteira.

Como conseqüência dessa sazonalidade, durante os meses de abril a setembro (entressafra), tem-se uma diminuição na oferta do produto, resultando num menor volume de leite disponivel para a produção de queijos. Essa época de menor produção coincide com o período em que ocorre uma maior procura pelo produto, gerando falta de certos tipos de queijos no mercado, entre os quais a Mussarela, bem como uma elevação no preço dos mesmos.

Uma medida que poderia ser adotada visando solucionar, pelo menos parcialmente, o problema da sazonalidade, estabilizando a oferta, seria a desidratação do leite excedente, produzido no período de safra, e a sua reconstituição na entressafra, de acordo com as variações no consumo de queijos e demais derivados lácteos.

Este experimento teve por objetivo determinar a porcentagem ideal de leite reconstituído que pode ser adicionada, ao leite in natura, na fabricação de queijo Mussarela para uso em pizzas, sem que ocorram alterações na sua composição físicoquímica e nas suas características e propriedades funcionais. 


\section{REVISÃO DE LITERATURA}

\subsection{Queijos de massa filada}

"Massa Filada" é um termo utilizado para se referir a certas variedades de queijos que, através de um processo especial de produção, dão origem a uma coalhada que, após ser dessorada e suficientemente acidificada, é então colocada em água quente. Essa coalhada, devidamente acidificada e aquecida, quando submetida a tensões mecânicas, apresentará a capacidade de "filar", ou seja, de se estender formando fios (Del Prato, 1993).

Portanto, queijos de massa filada são queijos que se caracterizam por apresentarem, durante o seu processamento industrial, uma operação denominada filagem, a qual modifica a estrutura granulosa e descontínua da massa para uma estrutura contínua e filamentosa (Valle, 1991).

Segundo Furtado (1991) e Oliveira(1982), os principais tipos de queijos filados são: Mussarela (tipo de queijo filado mais consumido no mundo, sendo normalmente consumido fresco, sem maturação); Scarmoza (queijo com características similares a Mussarela); Provolone (um dos mais famosos e apreciados queijos de massa filada, é defumado e maturado, apresentando-se em uma variedade suave e uma picante) e Caccio-Cavalo (queijo similar ao provolone, não defumado, sendo tradicionalmente maturado, embora em muitos países seja vendido fresco, como a Mussarela). 


\subsection{Tipos e características do queijo Mussarela}

A Mussarela tem uma longa história, datando dos tempos medievais, sendo sua origem italiana, na planície de Nápoles. O nome Mussarela deriva do verbo "mozzare", que significa repartir ou fatiar, que é uma importante característica da Mussarela ou uma alusão a uma etapa do seu processamento, na qual o queijeiro reparte a massa em pedaços para filá-la(Del Prato, 1993).

Esse queijo de massa filada é tido como um queijo macio, não maturado, levemente salgado, de coloração branca ou levemente amarelada, com uma superficie brilhante, podendo ser encontrado em formato irregular, retangular, periforme ou ovóide, pesando poucas gramas até vários quilos (Jana, 1991 e Valle, 1991).

\subsubsection{Tipos}

Nos Estados Unidos, de onde provêm as maiores pizzarias no estilo "fast food",o queijo Mussarela é dividido em 4 categorias, com base no seu teor de umidade e na sua porcentagem de gordura no extrato seco (GES), como indicado na Figura 1.

\begin{tabular}{|lcc|}
\hline \multicolumn{1}{|c}{ Categoria } & Umidade (\%) & GES (\%) \\
\hline Regular & $>52 \leq 60$ & $\geq 45$ \\
Baixa umidade & $>45 \leq 52$ & $\geq 45$ \\
Baixa umidade parcialmente desnatada & $>45 \leq 52$ & $\geq 30<45$ \\
Parcialmente desnatada & $>52 \leq 60$ & $\geq 30<45$ \\
\hline
\end{tabular}

Figura 1. Categorias de Mussarela de acordo com seu teor de umidade e \% GES ( Jana, 1991 e Kindstedt, 1993b).

Mussarela regular e Mussarela parcialmente desnatada apresentam um alto teor de umidade ( $>52 \%$ ), sendo freqüentemente consumidas frescas, como queijos de mesa. 
Raramente são utilizadas como ingrediente para pizza devido a sua propriedade de fatiamento ruim. Em contraste, Mussarela baixa umidade e Mussarela baixa umidade parcialmente desnatada têm um menor teor de umidade (47-48\%), corpo mais firme e um bom fatiamento, o que permite seu uso em pizzas (Jana, 1991 e Kindstedt, 1993b).

\subsubsection{Padrões legais}

\subsubsection{Padrões físico-químicos}

De acordo com Kindstedt (1993b), levantamentos da composição química de queijos Mussarela comerciais, nos Estados Unidos, têm mostrado uma larga variação, nos níveis de umidade, gordura no extrato seco(GES), sal e proteína, entre as várias marcas comerciais, em todas as categorias de queijo Mussarela(Figura 2).

\begin{tabular}{|lcccc|}
\hline \multicolumn{1}{|c}{ Categoria } & Umidade (\%) & GES(\%) & Sal(\%) & Proteína(\%) \\
\hline Regular & $48-60$ & $44-53$ & $1,2-3,5$ & $21-22$ \\
Baixa umidade & $44-56$ & $35-56$ & $0,8-2,7$ & $18-28$ \\
Baixa umidade parcial. desn. & $44-56$ & $31-53$ & $0,8-3,3$ & $20-30$ \\
Parcialmente desnatada & $51-56$ & $30-50$ & $0,7-1,2$ & 22 \\
\hline
\end{tabular}

Figura 2. Categorias de Mussarela de acordo com seu teor de umidade e \% GES (Kindstedt, 1993b).

Na Argentina, o queijo Mussarela deve ter um teor de umidade menor ou igual a $60 \%$ e um teor de GES maior ou igual a 35\%(Dianda, 1982).

Schiftan \& Komatsu (1979) relatam que um máximo de $58 \%$ de umidade e um mínimo de $28 \%$ de GES são prescritos para queijos Mussarela no estado de São Paulo. 
Entretanto, de acordo com a Nova Legislação de Produtos Lácteos (1998), o queijo Mussarela produzido no Brasil, destinado ao comércio nacional ou internacional, deve obedecer os seguintes requisitos: um teor de umidade máximo de $60 \%$ e um teor de GES mínimo de $35 \%$.

\subsubsection{Padrões microbiológicos}

A Portaria 146, de 07/03/1996, do Ministério da Agricultura, do Abastecimento e da Reforma Agrária- MAARA, publicada no Diário Oficial de 11/03/1996, que entrou em vigor em 11/05/1996, determina os padrões microbiológicos para a Mussarela, os quais são listados no Figura 3(Furtado \& Lourenço Neto, 1997b).

\begin{tabular}{|lccrrl|}
\hline Microorganismo & $\mathrm{n}^{1}$ & $\mathrm{c}^{2}$ & $\mathrm{~m}$ & \multicolumn{1}{c|}{ M } & Método de Análise \\
\hline Coliformes/g $\left(30^{\circ} \mathrm{C}\right)$ & 5 & 2 & 1.000 & 5.000 & FIL 73A:1985 \\
Coliformes/g $\left(45^{\circ} \mathrm{C}\right)$ & 5 & 2 & 100 & 500 & APHA: 1992 \\
Estafilococos coag ${ }^{+} / \mathrm{g}$ & 5 & 2 & 100 & 1.000 & FIL 145:1990 \\
Salmonella spp/25g & 5 & 0 & 0 & 0 & FIL 93A:1985 \\
Listeria monocytogenes $/ 25 g$ & 5 & 0 & 0 & 0 & FIL 143:1990 \\
\hline
\end{tabular}

Figura3.Requisitos Microbiológicos para a Mussarela(Furtado \& Lourenço Neto, 1997b). $\mathrm{n}^{1}$ corresponde ao número de peças que serão analisadas.

$\mathrm{c}^{2}$ corresponde ao número máximo de peças que poderão apresentar contagens entre os valores designados para $\mathrm{Me} \mathrm{m}$.

\subsubsection{Valor nutricional}

Segundo Mendes (1997); Oliveira(1982) e Torres (1996), o queijo é considerado um alimento altamente nutritivo, dados os seus teores de proteínas, gordura, cálcio, fósforo e vitaminas (Figura 4). As proteínas, presentes no queijo, são de alto valor biológico, sendo consideradas proteínas completas, como as da carne e as do ovo. Sob o 
ponto de vista vitamínico, são ótima fonte de vitamina $A$, a qual fica dissolvida na gordura retida no queijo.

\begin{tabular}{|cccccccc|}
\hline Produto & Calorias & $\begin{array}{c}\text { Proteínas } \\
(\mathrm{g})\end{array}$ & $\begin{array}{c}\text { Lipídios } \\
(\mathrm{g})\end{array}$ & $\begin{array}{c}\text { Glicídios } \\
(\mathrm{g})\end{array}$ & $\begin{array}{c}\text { Cálcio } \\
(\mathrm{mg})\end{array}$ & $\begin{array}{c}\text { Fósforo } \\
(\mathrm{g})\end{array}$ & $\begin{array}{c}\text { Ferro } \\
(\mathrm{mg})\end{array}$ \\
\hline $\begin{array}{c}\text { Leite } \\
\text { Pasteurizado }\end{array}$ & 61 & 3,6 & 3,0 & 4,9 & 123 & 96 & 0,1 \\
Queijo Minas & 243 & 18,0 & 19,0 & - & 685 & 430 & 0,4 \\
$\begin{array}{c}\text { Fresco } \\
\text { Queijo Prato }\end{array}$ & 392 & 28,3 & 30,6 & 0,6 & 840 & 630 & 0,6 \\
$\begin{array}{c}\text { Mussarela } \\
\text { (leite-búfala) }\end{array}$ & 280 & 20,0 & 24,5 & 0,6 & 400 & 240 & 0,2 \\
$\begin{array}{c}\text { Mussarela } \\
\text { (leite-vaca) }\end{array}$ & 265 & 20,0 & 21,0 & 0,7 & 160 & 350 & 0,4 \\
\hline
\end{tabular}

Figura 4. Quadro nutricional do leite pasteurizado e dos 3 principais queijos consumidos no Brasil por 100 gramas de parte comestível (Del Prato, 1993 e Torres, 1996).

Além de seu conteúdo protéico e vitamínico, o queijo constitui-se, ao lado do leite, como a maior fonte de cálcio absorvível a disposição do organismo, contendo também altos teores de fósforo em sua composição (Mendes, 1997).

\subsection{Propriedades funcionais da Mussarela}

Segundo Furtado \& Lourenço Neto (1997c), na indústria queijeira o segmento produtor de Mussarela está passando por uma forte mudança de conceito mercadológico, patrocinada principalmente pelas redes de pizzarias no estilo "fast food", recentemente instaladas no Brasil. Na realidade, o conceito tradicional de Mussarela está sendo revisto e adaptado gradualmente para o moderno conceito de "pizza cheese", no qual as 
propriedades funcionais da Mussarela têm um papel fundamental, sendo que essas propriedades, assim como outras características importantes na avaliação da qualidade de uma Mussarela, são fortemente influenciadas pelo processo de degradação de proteínas(proteólise).

\subsubsection{Noções gerais sobre proteólise}

Segundo Cheftel et al.(1989), em um leite de vaca normal, o conteúdo médio de proteínas é de 30-35gramas/litro, sendo que essas proteínas dividem-se em 6 grupos principais, sendo 4 grupos de caseínas (alfa $a_{\mathrm{s} 1}$, alfa $\mathrm{al}_{\mathrm{s} 2}$, beta e kapa) e 2 de proteínas do soro(beta-lactoglobulina e alfa-lactoalbumina). Cerca de $80 \%$ dessas proteínas se encontram na forma de complexos macromoleculares, contendo uma parte mineral (especialmente fosfato de cálcio), conhecidos pelo nome de micelas. As caseínas se encontram presentes basicamente nesta forma (Figura 5).

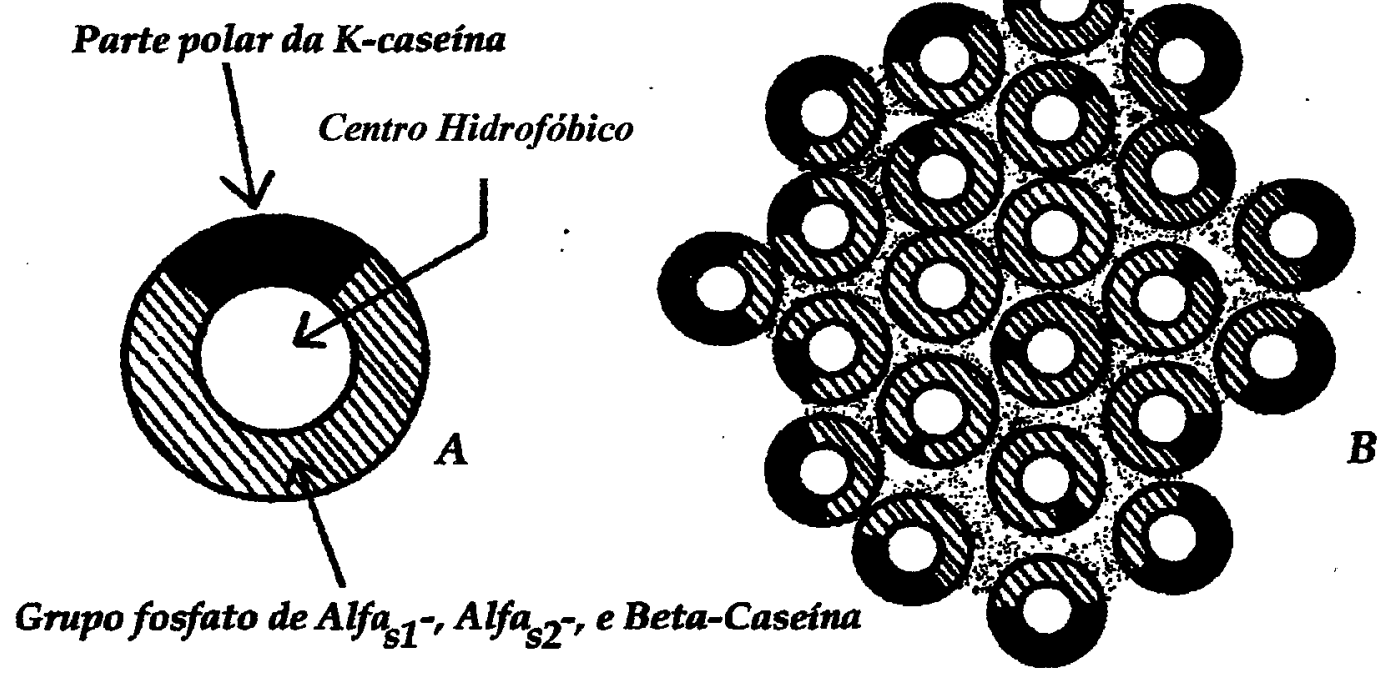

Figura 5: Modelo de uma submicela de caseína(A) e de uma micela de caseína composta de submicelas e fosfato de cálcio coloidal(B). Parte salpicada: fosfato de cálcio coloidal (Schmidt, 1980). 
Nesse modelo, a kapa-caseína se encontra localizada preferencialmente na superficie (tendo sua frente polar-hidrofilica orientada para a face aquosa do leite), encobrindo as outras caseínas(alfa $\mathrm{al}_{\mathrm{s} 1}$, alfa $\mathrm{af}_{\mathrm{s} 2}$ e beta), que se encontram no interior, "cimentadas" pelo chamado fosfato de cálcio coloidal.

De acordo com Wolfschoon-Pombo \& Lima (1989), pode-se imaginar um queijo como uma estrutura ou matriz de caseína, na qual encontram-se presos ou retidos os outros elementos do leite, como a gordura e a água, e nesta última, os constituintes hidrossolúveis (lactose, proteínas solúveis, sais, etc).

O queijo, desde antes da sua fabricação até o fim de sua vida de prateleira sofre inúmeras transformações físico-químicas que são decisivas para o corpo (consistência) e textura (estrutura) do produto, afetando também o flavor. Uma dessas transformações consiste na degradação de proteínas, na chamada proteólise (Wolfschoon-Pombo, 1983).

Essa degradação ocorre por meio da ação das enzimas naturalmente presentes no leite (plasmina), das enzimas do coalho e daquelas produzidas por bactérias do fermento lático e por outros microorganismos contaminantes (Seminário Internacional sobre Pizza Cheese, 1997 e Wolfschoon-Pombo \& Lima, 1989). A Figura 6 sintetiza esquematicamente a proteólise da caseína, por meio da ação dessas enzimas.

\title{
Caseína
}

\author{
fermento lático $\Downarrow$ coalho \\ peptídeos de alto peso molecular \\ fermento lático $\Downarrow$ coalho e plasmina \\ peptídeos de baixo peso molecular \\ fermento lático $\Downarrow$ plasmina \\ aminoácidos
}

Figura 6: Efeito das atuações do coalho, do fermento e da plasmina sobre a caseína (Wolfschoon-Pombo \& Lima, 1989) 
O coalho mais utilizado atualmente, nas fábricas de queijos, é formado por uma mistura das enzimas quimosina e pepsina bovina ( $80 \%$ e $20 \%$, respectivamente). Após participar ativamente do processo de coagulação do leite, a maior parte da atividade proteolítica desse coalho é removida junto com o soro, restando, entretanto, um resíduo do mesmo após a prensagem, o qual terá uma ação proteolítica principalmente sobre a

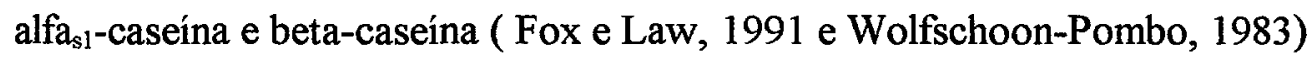

O fermento lático atua sobre as proteínas beta-caseína e kapa-caseína, enquanto que a plasmina hidrolisa as caseínas alfa $\mathrm{s}_{\mathrm{s}}$, alfa $\mathrm{s}_{\mathrm{s} 2}$ e beta (Fox e Law, 1991 e Grappin et al., 1985).

A ação de todas essas enzimas tende a diminuir quanto maior a porcentagem de sal na fase aquosa do queijo e quanto menor a temperatura de armazenamento. Portanto, a degradação das caseínas tende a ser menor em queijos mais salgados e armazenados a baixas temperaturas(Kindstedt et al., 1992).

Durante um período de cerca de 2 a 3 semanas, após a sua fabricação, a Mussarela passa por um processo de amaciamento resultante da hidrólise da alfa $\mathrm{s}_{\mathrm{s} 1}$-caseína a alfa $_{\mathrm{s} 1}$-peptídeo, sendo a quimosina o principal agente proteolítico nessa fase (Fox, 1988). Após esse amaciamento inicial, as mudanças na textura e consistência do queijo, pela ação das enzimas proteolíticas, continuarão a ocorrer, mas numa velocidade menor, e serão mais adequadamente medidas em meses do que em dias (Lawrence et al, 1987).

De acordo com Wolfschoon-Pombo \& Lima (1989), a atividade proteolítica em queijos pode ser avaliada por meio de 2 índices: extensão e profundidade da proteólise.

A extensão da proteólise se caracteriza pela quantidade de substâncias nitrogenadas solúveis acumuladas durante o processo, e expressadas como porcentagens do nitrogênio total. Esse índice é melhor conhecido como índice de maturação e sua determinação analítica é baseada na precipitação isoelétrica da caseína a $\mathrm{pH}$ menor que 4,6, em uma amostra diluída do queijo, e quantificação das substâncias solúveis através do método de Kjeldahl (Wolfschoon-Pombo, 1983). 
A profundidade da proteólise abrange as substâncias nitrogenadas de baixo peso molecular, acumuladas durante o processo. Compostos característicos são os aminoácidos, oligo-peptídeos, aminas, etc. A profundidade pode ser quantificada pelo teor em nitrogênio não protéico-NNP (teor de substâncias de baixo peso molecular, que não se precipitam na presença de ácido tricloroacético a 12\%) expressado como porcentagem da proteína solúvel total ou do nitrogênio total (Wolfschoon-Pombo, 1983).

\subsubsection{Propriedades da Mussarela não derretida}

Apesar da maioria das Mussarelas serem usadas com o objetivo de fusão, as propriedades físicas do queijo, antes da fusão, também são importantes. Quando usada para pizza ou para outras aplicações, o queijo deve ser primeiro fatiado ou moído, em fatias ou partículas de tamanho uniforme, para facilitar uma adequada fusão e distribuição do queijo sobre a pizza. Portanto, o fatiamento, a moagem e a resistência ao agregamento, após a moagem, são determinantes da qualidade do queijo (Kindstedt, 1993b e Savage \& Mullan, 1996).

\subsubsection{Propriedades da Mussarela derretida}

As propriedades fisicas do queijo Mussarela fundido são altamente complexas e dão origem a pelo menos 4 importantes características funcionais: Derretimento, Elasticidade, Separação de óleo livre e Escurecimento não enzímico (Kindstedt, 1993b).

\subsubsection{Derretimento}

Refere-se a habilidade da massa em derreter-se com relativa facilidade sobre a pizza, de maneira homogênea e sem a formação de bolhas muito grandes (Seminário Internacional sobre Pizza Cheese, 1997). 
Segundo levantamentos feitos na Inglaterra, por Savage \& Mullan (1996), a maioria dos fabricantes de Mussarela e produtores de pizza consideram um bom derretimento como uma das principais características exigidas pelo consumidor, sendo que existem vários procedimentos que podem ser utilizados para medir o derretimento de uma Mussarela.

Os métodos tradicionais de avaliação da propriedade de derretimento da Mussarela baseiam-se na retirada de amostras do queijo, apresentando essas amostras o formato de pequenos discos, de dimensões especificadas, as quais são submetidas a um processo de aquecimento, sob condições de tempo e temperatura previamente definidas. O derretimento é , então, expresso em função da diminuição na altura da amostra ou através do aumento da área do disco (Arnott et al., 1957; Kindstedt et al., 1989b e Park et al., 1984).

Testes mais recentes têm avaliado o derretimento da Mussarela baseando-se na medição da sua viscosidade (resistência da massa em se deformar e a fluir). Esses testes apresentam a vantagem de fazerem uso de amostras maiores, as quais possibilitam uma amostragem mais representativa do queijo, além do fato de que alguns deles fornecem também informações sobre a elasticidade e resistência ao estiramento apresentadas pelo queijo (Kindstedt et al., 1989a; Kindstedt et al., 1989b e Rippe \& Kindstedt, 1988).

Existem fatores que podem melhorar ou piorar o derretimento da Mussarela. Altos teores de umidade nos queijos e teores elevados de gordura conferem uma maior tendência ao derretimento (McMahon et al., 1993 e Tunick et al., 1991). Por outro lado, teores elevados de sal, bem como altos valores de $\mathrm{pH}$ da massa a ser filada diminuem o derretimento (Furtado, 1997c e Kindstedt, 1991). Com relação ao período de estocagem, o derretimento aumenta significativamente durante o período de armazenamento, devido a proteólise (Oberg et al., 1991b e Yun et al., 1992). 


\subsubsection{Elasticidade}

Por elasticidade entende-se a capacidade da Mussarela, derretida sobre a pizza, de esticar-se, distanciando-se da massa quando puxada com um garfo. A tendência é de exigir-se um queijo de boa qualidade e que ao se esticar, não se arrebente e mantenha ainda uma certa aderência à superficie da pizza (Seminário Internacional sobre Pizza Cheese, 1997).

Dois testes instrumentais são sugeridos por Apostolopoulos (1994) para avaliar a habilidade do queijo Mussarela de esticar-se, quando derretido, formando fios longos. Um deles consiste basicamente de um teste de estiramento, assemelhando-se ao que é feito normalmente pelo consumidor com o garfo. O segundo consiste de um teste fundamental onde o queijo derretido é submetido a uma compressão, sendo a elasticidade do queijo avaliada com base na sua elongação.

A maior ou menor elasticidade de um queijo Mussarela depende de inúmeros fatores, sendo a proteólise o mais importante deles. Em queijos recém fabricados, uma certa atividade proteolítica é desejável, pois os mesmos contém um alto teor de caseína intacta, apresentando-se muito firmes, o que prejudica a elasticidade (Furtado \& Lourenço Neto, 1993c e McMahon et al.,1993). Após cerca de 2 a 3 semanas de armazenamento refrigerado a $8-10^{\circ} \mathrm{C}$, os queijos atingem um máximo de elasticidade (Furtado, 1997a), sendo que a partir daí, a medida que a degradação da matriz protéica vai aumentando, a mussarela derretida vai perdendo progressivamente sua capacidade de estirar-se, passando a romper-se facilmente, quando esticada (Furtado \& Lourenço Neto, 1993c e McMahon et al.,1993).

Quanto mais elevado o teor de umidade do queijo, o seu tempo e temperatura de estocagem e a proporção de bacilos na composição do fermento, maior será a sua proteólise e mais rapidamente ele perderá a sua capacidade de estirar-se, quando derretido sobre a pizza(Furtado \& Lourenço Neto, 1997c; McMahon et al., 1993 e Yun et al., 1995a). Deve-se., portanto, evitar o uso de coalhos fúngicos ou contendo pepsina 
suína, por apresentarem alta atividade proteolítica (Furtado \& Lourenço Neto, 1997c e Kindstedt, 1993b).

Aumentando-se o teor de gordura do queijo também diminui-se a elasticidade e aderência da massa na pizza (McMahon et al., 1993).

Mussarela muito salgada e massas filadas a temperaturas muito elevadas sofrerão menor proteólise e consequentemente terão uma maior elasticidade (Furtado, 1997c e Kindstedt, 1993a).

\subsubsection{Separação de óleo livre}

Conhecida tecnicamente como "free oil" (FO) ou "oiling off", essa característica refere-se a indesejável separação de óleo durante o processo de derretimento da Mussarela sobre a pizza (Furtado, 1997c).

O teste tradicional para determinação de FO envolve o derretimento de discos de queijo, de dimensões específicas, sobre papéis de filtro, sendo as condições de tempo e temperatura de aquecimento previamente definidas (Bertola et al., 1996 e Breene et al., 1964). Durante o aquecimento, óleo é liberado pelo disco, sendo absorvido pelo papel de filtro, formando uma mancha, cuja área é determinada, sendo o FO expresso em função da área original do disco (Kindstedt \& Rippe, 1990 e Nilson \& Laclair, 1976).

Entretanto, devido a dificuldade em se obter uma amostragem representativa de blocos grandes de Mussarela, testes de determinação de FO baseados nos métodos de Babcock (Kindstedt \& Rippe, 1990) e de Gerber (Kindstedt \& Fox, 1991) vêm sendo muito utilizados nos Estados Unidos e na Europa.

A proteólise aumenta o problema de separação de óleo, portanto, deve-se evitar porcentagens elevadas de bacilos nos cultivos, assim como o uso de coalhos fúngicos, devido a alta atividade proteolítica apresentada pelos mesmos (Furtado \& Lourenço Neto, 1997c). 
A formação de FO também é influenciada pelo periodo de estocagem, apresentando um aumento acentuado durante as primeiras duas semanas, seguido de um crescimento mais moderado nas semanas seguintes (Kindstedt, 1993b).

O nível de gordura, nos queijos, é um dos maiores determinantes da quantidade de FO, sendo que na Mussarela a gordura se encontra na forma de glóbulos dispersos na matriz de caseína (Kindstedt, 1993a). Durante o aquecimento, esses glóbulos se unem formando áreas de acúmulo de óleo que fluem com o colapso da matriz protéica, sendo que a tendência dos glóbulos se unirem, fluírem e por último serem liberados como “oiling off” depende do grau de emulsificação dos mesmos (Tunick et al., 1989).

Tunick (1994) e Kindstedt (1993a) relatam que a homogeneização do leite, a ser usado na fabricação da Mussarela, principalmente a altas pressões $(6700 \mathrm{KPa})$, resulta em menores e mais altamente emulsificados glóbulos de gordura, os quais permanecem emulsificados na massa de queijo, contribuindo para a formação de um nível menor de FO no queijo derretido.

Kindstedt (1991) propôs que o teor de sal também afeta as características de FO. Essa teoria baseou-se na observação de que FO era significativamente menor na superficie dos queijos, do que no seu interior e que isso se devia ao fato da concentração de sal na superficie dos queijos avaliados ser maior do que na região central. De acordo com Kindstedt (1993b) e Shimp (1995), a maior concentração de sal, na superficie da mussarela, diminui a formação de FO devido a uma troca do cálcio, ligado à caseína, pelo sódio, sendo que essa mudança favorece uma maior emulsificação da gordura, pois a caseína se torna um agente emulsificante mais eficiente quando dissociada do cálcio.

\subsubsection{Escurecimento não enzímico}

Esse característica funcional refere-se a formação localizada de manchas escuras ou amarronzadas sobre o queijo derretido na pizza. Tradicionalmente não era tida como um defeito e sim como uma conseqüência normal do processo de elaboração da 
Mussarela e de seu derretimento à altas temperaturas. Mas considerando-se a demanda crescente de utilização de Mussarelas que se derretem, mantendo-se amareladas (ligeiramente douradas), esse escurecimento tem sido visto como um problema a ser evitado (Furtado, 1998b).

Segundo Hodge \& Osman (1976), o principal determinante desse escurecimento é a presença de resíduos de galactose e/ou lactose na Mussarela. O grupamento carbonila desses carboidratos reage com o grupamento amina dos aminoácidos (principalmente lisina), resultantes da degradação de proteínas, dando origem a um conjunto de reações bioquímicas complexas, denominado de Reação de Maillard. Essa reação ocorre quando o produto é submetido a temperaturas elevadas e ela resulta na formação de melanoidinas, denominação genérica de um grupo de componentes de pigmentação amarronzada, que conferem a Mussarela, derretida na pizza, manchas com essa coloração típica.

O acumulo de galactose na massa é devida ao uso, na fabricação de Mussarela, de culturas láticas que contêm microorganismos galactose negativos (maioria dos strains de Streptococcus salivarius ssp thermophilus e Lactobacillus delbruekii ssp bulgaricus), ou seja, que não metabolizam o carboidrato galactose por não possuírem a enzima galactoquinase. A ausência dessa enzima impedirá que a galactose sofra uma série de reações que permitiriam a sua entrada na via glicolítica, como glucose 6-P (Furtado, 1997c e Johnson \& Olson, 1985).

É preciso considerar também que, dependendo do processo de fabricação, a própria lactose pode permanecer residual (sem ser fermentada) no queijo, após a massa atingir seu $\mathrm{pH}$ ideal de filagem, ser filada, embalada e armazenada (Hodge \& Osman, 1976).

Análises descritivas visuais do queijo Mussarela, derretido sobre a pizza, têm sido usadas por diversos pesquisadores para estudar as propriedades do escurecimento não enzimático (Kindstedt, 1993b). 
A formação de manchas escuras é um fenômeno relativamente complexo, pois envolve muitos fatores. Por outro lado, pode-se afirmar que todas as medidas de controle apontariam para uma mesma direção, ou seja, a eliminação ou diminuição do teor residual de açúcar e a diminuição da intensidade da proteólise, para reduzir a disponibilidade de grupos amina.(Furtado, 1997c).

A diminuição do teor residual de açúcar pode ser conseguida de várias formas: fazendo uso de um fermento que contenha em sua composição Lactobacillus helveticus, o qual fermenta completamente a lactose e pode, também, fermentar galactose livre (Turner \& Martley, 1983); controlando a temperatura da massa, durante a filagem, para que ela não ultrapasse $58-60^{\circ} \mathrm{C}$, o que provocaria uma danificação celular, com perda da atividade do fermento(Furtado \& Lourenço Neto, 1997c); evitando um teor elevado de sal no queijo, uma vez que o sal inibe a atividade da cultura (McMahon et al, 1993) e eliminando o máximo de lactose da massa, sem prejudicar uma adequada desmineralização da mesma, através de uma lavagem da massa com água abundante, antes da filagem (Furtado, 1997c e Kindstedt, 1993b).

Uma diminuição da intensidade de proteólise pode ser conseguida evitando o uso de coalhos com alta atividade proteolítica, bem como a fabricação de queijos com teores elevados de umidade (Furtado, 1997c e Kindstedt, 1991).

De acordo com Kindstedt (1993a), as características de escurecimento não enzímico são também dependentes do período de estocagem do queijo, sendo que um alto grau de escurecimento ocorre quando o queijo é fresco. Entretanto, essa susceptibilidade diminui drasticamente durante as 2 primeiras semanas, aumentando progressivamente nas semanas posteriores.

\subsection{Etapas da fabricação do queijo Mussarela}

$\mathrm{Na}$ literatura encontram-se algumas tecnologias disponíveis para a obtenção do queijo Mussarela. Entre essas, a tecnologia tradicional (Figura 7) é, sem dúvida, a mais 
utilizada no mundo todo e, principalmente no Brasil, sendo que as etapas de fermentação e filagem são as mais importantes para a obtenção do produto dentro dos padrões recomendados e com menores perdas de rendimento (Valle, 1991).

Escolha do tipo de leite

Pasteurização e padronização

Adição de fermento ao leite

Adição de coadjuvantes de processamento

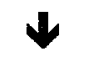

Coagulação

Corte e Mexedura

$\downarrow$

Aquecimento e delactosagem

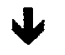

Dessoragem e pré-prensagem

Fermentação

$\downarrow$

Filagem e moldagem

Resfriamento

Salga e secagem

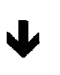

Estabilização e comercialização

Figura 7. Etapas da produção de queijo Mussarela pelo processo tradicional (Furtado \& Lourenço Neto, 1997a). 


\subsubsection{Escolha do tipo de leite}

A coloração branca, no queijo Mussarela, é uma característica desejada por alguns industriais, o que se torna dificil quando o queijo é feito de leite de vaca, devido a presença de caroteno (Jana, 1991). Assim, para se obter uma Mussarela de tonalidade mais similar àquela observada no queijo feito com leite de búfala, pode-se usar agentes descolorantes, com componentes a base de clorofila ou dióxido de titânio (Furtado, 1997a).

Bonassi et al. (1982) não encontraram diferenças significativas no sabor, aroma ou textura de queijos feitos de leite de vaca e de búfala. Não encontraram também diferenças em termos de $\mathrm{pH}$, acidez titulável, umidade e teor de proteínas. Entretanto, o queijo Mussarela elaborado com leite de búfala obteve rendimentos superiores em relação ao elaborado com leite de vaca (Bonassi et al., 1982 e Rossi, 1977), embora apresentasse um pior derretimento, quando submetido a aquecimento (Mostafa et al., 1996).

\subsubsection{Pasteurização e padronização do leite}

Conforme consta na Portaria 146, do Ministério da Agricultura, só podem ser elaborados com leite cru queijos que sejam maturados por, no mínimo, 60 dias. Portanto, como a Mussarela é considerada um queijo fresco, não pode ser feita com leite cru (Brasil, 1976).

A temperatura ideal de pasteurização do leite seria de $71-73^{\circ} \mathrm{C}$ por $15-20$ segundos, a qual garantiria a qualidade higiênica do produto e não causaria problemas de filagem (Furtado, 1997a e Sghedoni et al.,1979).

Segundo Furtado \& Lourenço Neto (1997a), na fabricação de Mussarela a padronização do teor de gordura do leite deve ser feita de forma que o queijo apresente uma GES de cerca de $40 \%$ e um teor de umidade de $45-50 \%$. 


\subsubsection{Fermentação natural biológica e acidificação direta}

A Mussarela, assim como todo queijo de massa filada, precisa passar por uma etapa de acidificação, durante o seu processamento, a qual confere à massa características que permitem que a mesma, ao ser colocada em água quente, torne-se plástica e possa ser trabalhada de modo a formar fibras longas, que conferirão ao queijo sua estrutura fibrosa característica. Essa acidificação da massa pode ocorrer por meio de uma fermentação natural biológica do leite (tecnologia tradicional) ou através de um processo de acidificação direta.

\subsubsection{Fermentação biológica}

O uso de fermentos láticos na fabricação de Mussarela é importante porque, na fase de elaboração e fermentação da massa, eles são responsáveis pela produção de acidez e desmineralização da coalhada e, na fase de armazenamento e estabilização, conferem uma proteólise limitada da caseína (Furtado, 1997a).

Para manufatura de Mussarela de alta umidade sugere-se comumente um fermento mesófilo (Lactococcus lactis ssp lactis e Lactococcus lactis ssp cremoris), enquanto que para Mussarela de baixa umidade (pizza cheese) tem sido recomendado o uso de um fermento termófilo (Streptococcus salivarius ssp thermophilus, Lactobacillus delbruekii ssp bulgaricus e/ou Lactobacillus helveticus), o qual apresenta a vantagem de acidificar mais rapidamente a massa, permitindo a sua filagem no mesmo dia da sua fabricação (Del Prato, 1993 ; Furtado, 1991 e Production ...,1977).

$\mathrm{Na}$ escolha do fermento termófilo, deve-se considerar que a maioria dos strains de Streptococcus salivarius ssp thermophilus e Lactobacillus delbrueckii ssp bulgaricus são inábeis para metabolizar a galactose, enquanto que Lactobacillus helveticus fermentam a lactose completamente e podem também fermentar galactose livre, reduzindo o escurecimento não enzímico. Por outro lado, Lactobacillus helveticus são altamente proteolíticos o que aumenta o "oiling-off", além de comprometer a elasticidade 
da massa (Furtado, 1997c; Kindstedt, 1993b e Oberg et al., 1991a). Com base nessas considerações, o fermento termófilo mais utilizado atualmente é composto de uma mistura de Streptococcus salivarius ssp thermophilus e Lactobacillus helveticus (Kindstedt, 1993a; Oberg et al., 1991 b e Yun et al., 1995a).

Num processo mais recente, tem-se utilizado, em combinação com os fermentos termófilos, culturas lactose-fermentativas não tradicionais, como Pediococcus cerevisiae, Lactobacillus plantarum e Lactobacillus casei (Seminário Internacional sobre Pizza Cheese, 1997).

\subsubsection{Acidificação direta}

Consiste na adição, no lugar do fermento, de um ácido orgânico ou inorgânico ao leite frio ou à temperatura de coagulação, em quantidade suficiente para abaixar instantaneamente o $\mathrm{pH}$ do leite para cerca de 5,6-5,8 (Breene et al., 1964; Del Prato, 1993; Furtado, 1997a; Larson et al., 1967; e Valle, 1991). Os diferentes tipos de ácidos utilizados nessa técnica incluem: ácido hidroclórico, fosfórico, lático, acético, málico ou cítrico (Breene et al., 1964; Jana, 1991; Quarne et al., 1968 e Shehata et al., 1967).

As vantagens no uso da acidificação direta são: redução de cerca de 3-4 horas no tempo total de fabricação da Mussarela, uma vez que a massa pode ser filada cerca de 310 minutos após a sua dessoragem (Kim \& Yu, 1988; Larson et al., 1967 e Valle, 1991),

e diminuição de cerca de 50\% na quantidade de coalho a ser utilizada (Micketts \& Olson, 1974 e Valle, 1991).

\subsubsection{Adição de coadjuvantes de processamento}

\subsubsection{Cloreto de cálcio $\left(\mathrm{CaCl}_{2}\right)$}

No processo de coagulação do leite, a presença de cálcio solúvel - sob a forma ionizada com duas cargas positivas - é essencial, pois o cálcio estabelece uma ponte entre 
as micelas de paracaseína, formando uma rede: a coalhada. Porém, durante a pasteurização, parte desse cálcio ionizado é insolubilizado, diminuindo a aptidão do leite para a coagulação (Furtado, 1997b). Assim, a adição de $\mathrm{CaCl}_{2}$, ao leite, visa reduzir o seu tempo de coagulação, além de aumentar a firmeza da coalhada, resultando em uma menor perda de sólidos na hora do corte (Cheng et al., 1997).

Na prática, 20-25 gramas de $\mathrm{CaCl}_{2}$ são utilizadas para cada 100 litros de leite, na forma de solução 50\% (Oliveira, 1982 e Souza, 1985).

\subsubsection{Coalho}

Coalhos de origem animal (quimosina e pepsina), vegetal e fúngica (proteases ácidas de Mucor miehei, M.pusillus e Endothia parasitica) tem sido utilizados na produção de Mussarela (Fox, 1988 e Jana,1991). Entretanto, a quimosina bovina é a protease ácida mais específica para a coagulação do leite bovino (Dalgleish, 1987). Em termos gerais, parece que as proteases não bovinas são geralmente mais proteolíticas do que a quimosina, o que pode comprometer as propriedades funcionais da Mussarela, durante o seu período de estabilização ou armazenamento (Kindstedt, 1993a e Quarne et al., 1968).

De modo a evitar uma atividade proteolítica acentuada, o que mais se tem utilizado, nos últimos tempos, é o coalho de origem bovina constituído por uma mistura de 2 enzimas: a quimosina, que é fundamental no processo de coagulação do leite e a pepsina, que é uma enzima que atua principalmente durante o período de armazenamento do queijo (Furtado, 1984).

\subsubsection{Coagulação}

As micelas ou partículas coloidais da caseína são constituídas de 3 frações protéicas principais, que são: "alfa $(\alpha)$ ", "beta $(\beta)$ ", e "kapa(K)", sendo que as caseínas alfa 
e beta são sensíveis aos íons cálcio e se insolubilizam em sua presença (Oliveira, 1982). No leite, essas frações se encontram protegidas do cálcio pela kapa-caseína, que as envolve, como um colóide protetor (Cheftel et al., 1989).

$\mathrm{Na}$ coagulação enzímica, a enzima proteolítica hidroliza a kapa-caseína, destruindo sua capacidade protetora e expondo as frações sensíveis ao cálcio. Essas frações tornam-se, então, instáveis e em conseqüência o leite transforma-se num gel, ou seja, coagula (Oliveira, 1982 e Roitman et al., 1987).

Segundo Cheftel et al., 1989; Fox, 1988; Roitman et al., 1987 e WolfschoonPombo, 1983, a coagulação das micelas de caseína, devido a ação proteolítica do coalho, compreende 2 fases distintas: Fase Primária e Fase Secundária.

Fase Primária: É a fase na qual ocorre a ação enzímica da quimosina a ligação que une os resíduos de fenilalanina(Phe)105 e metionina (Met)106 da kapa-caseína, com a resultante liberação de uma glicoproteína (106-169), muito polar e solúvel, e de uma parte hidrofóbica e pouco solúvel (1-105), chamada de para-k-caseína.

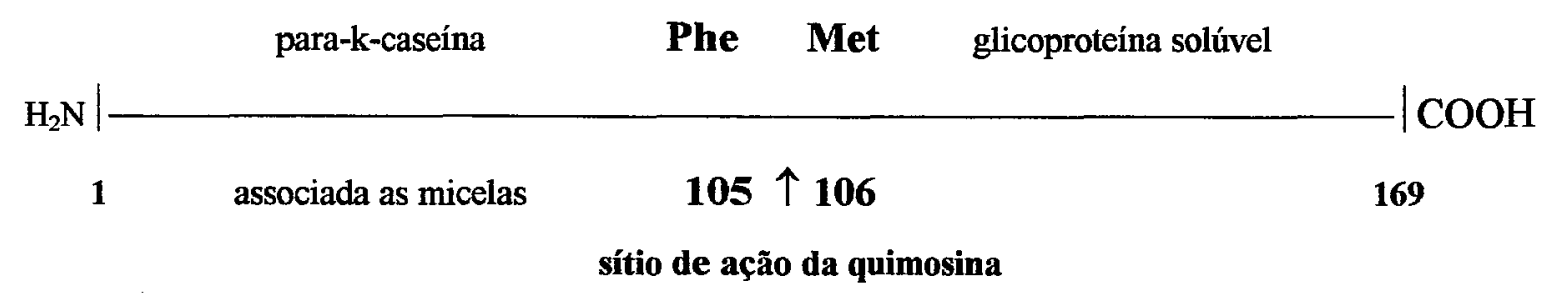

Fase Secundária: A para-k-caseína resultante, por ser sensível aos íons cálcio, precipita-se e também conduz a precipitação as outras frações da caseína, devido a perda do poder protetor da fração kapa, o que resulta na formação da coalhada.

$$
\text { Para-k-caseína }+\mathrm{Ca}^{++} \rightarrow \text { paracaseinato bicálcico (coágulo) }
$$

Durante a coagulação, o rompimento da k-caseína em outros locais, que não a ligação Phe105-Met106, são indesejáveis, levando a perdas de peptídeos solúveis. Assim, 
é importante que as enzimas utilizadas para coagulação sejam o mais específicas possíveis, apresentando um máximo de atividade coagulante e um mínimo de atividade proteolítica geral (Dalgleish, 1987).

A coagulação do leite para a fabricação de Mussarela deve ocorrer a temperatura de $30-35^{\circ} \mathrm{C}$, com duração de 30-50 minutos (Furtado \& Lourenço Neto, 1997a e Souza, 1985).

\subsubsection{Corte e mexedura}

$\mathrm{Na}$ conversão do leite em queijo, as micelas de caseína se agregam, formando uma rede protéica, a qual retém, em seu interior, a fase aquosa do leite (soro). A ruptura dessa rede causa a contração do coágulo, o que resulta na expulsão da fase aquosa, fenômeno esse conhecido como sinérese (Pearse \& Mackinlay, 1989). Portanto, o corte da coalhada, na forma de cubos, visa promover uma expulsão mais efetiva do soro, além de permitir que esses cubos sejam aquecidos mais uniformemente (Roitmam et al., 1987).

O corte da coalhada deve ser feito de modo a se obter cubos com cerca de 1-2 centímetros de aresta (Furtado \& Lourenço Neto, 1997a; Oliveira, 1982 e Oliveira \& Caruso, 1996). Ao finalizar o corte, inicia-se a agitação da coalhada, que deve ser lenta, no início, devido a fragilidade dos grãos. Essa agitação, que dura de 10-20 minutos, e é chamada de "primeira mexedura" evita a compactação da massa, no fundo do tanque, além de preparar os cubos para o aquecimento (Kosikowski, 1970 e Oliveira, 1982).

\subsubsection{Aquecimento e delactosagem}

O corte da coalhada em cubos e a sua constante agitação não são geralmente suficientes para se obter a intensidade de dessora desejada no queijo Mussarela. Assim sendo, visando acelerar e intensificar a dessora, após a primeira mexedura, eleva-se ligeiramente a temperatura do tanque de coagulação, a fim de se promover o chamado 
"cozimento" da massa, durante o qual a massa continua a ser agitada (segunda mexedura) (Oliveira, 1982).

A temperatura de aquecimento da massa influi na remoção de umidade da coalhada durante a fabricação do queijo, sendo que diferenças no nível de umidade podem ter um impacto significativo sobre a funcionalidade da Mussarela. Na maioria das fábricas brasileiras e americanas, essa temperatura de aquecimento varia de $37-45^{\circ} \mathrm{C}$, dependendo do tipo de fermento utilizado (Kindstedt et al., 1992 e Yun et al., 1993).

No caso do uso de fermentos termófilos, experimentos práticos têm demonstrado que o mais indicado é o uso de temperaturas intermediárias, na faixa de $39-42^{\circ} \mathrm{C}$, dentro da qual mantém-se um nivel adequado de umidade na massa e boas condições de crescimento para a flora termófila, como Streptococcus salivarius ssp thermophilus, Lactobacillus delbruekii ssp bulgaricus ou Lactobacillus helveticus (Furtado, 1997a).

Dois processos opcionais podem ser adotados na etapa de aquecimento da massa: Retirada de uma parcela do soro (cerca de 10-20\%) visando facilitar a agitação e o "cozimento" da massa (Souza, 1985) e retirada de parte do soro, com posterior adição de 20-40\% de água quente, visando uma diluição do soro, com redução na entrada de lactose no grão e conseqüente amenização do fenômeno de escurecimento não enzímico (Furtado, 1997a).

\subsubsection{Dessoragem e pré-prensagem}

Após cerca de 40-50 minutos do corte da coalhada, a massa normalmente apresenta a consistência desejada (ponto de massa). Atingido esse ponto, deve-se eliminar todo o soro e efetuar uma pré-prensagem da massa, com um peso equivalente a aproximadamente o dobro do peso da massa obtida, por um período de 10-20 minutos, com a finalidade principal de diminuir perdas operacionais de massa (Furtado \& Lourenço Neto, 1997a e Souza, 1985). 


\subsubsection{Fermentação da massa}

A operação de filagem é inteiramente dependente de uma prévia acidificação da massa e essa acidificação pode ser resultante de uma acidificação direta do leite, por meio da adição de um ácido, ou através da ação de bactérias láticas (tecnologia tradicional), as quais degradam a lactose, com a formação final de ácido lático (Oliveira, 1982).

No caso do uso de culturas láticas, o ácido lático formado reage gradualmente com o paracaseinato bicálcico (coalhada), removendo o cálcio da massa através da formação de lactato de cálcio (Del Prato, 1993). Este é o processo que ocorre tipicamente enquanto a massa está sendo fermentada antes da filagem. Simultaneamente, ocorre um abaixamento progressivo do $\mathrm{pH}$, até que a quantidade de cálcio ligando as micelas de paracaseína atinja um teor tal que permita que a massa, ao ser aquecida a 55$58^{\circ} \mathrm{C}$, venha a filar (Furtado, 1997c). Assim, segundo Furtado(1991) e Kosikowski(1970), com relação a capacidade de filagem, pode-se classificar o estado da massa fermentada em 3 categorias:

-Paracaseinato bicálcico: Massa excessivamente mineralizada, muito coesa e com baixa acidez; a massa não fila por não apresentar ainda elasticidade suficiente.

-Paracaseinato monocálcico: Massa com desmineralização média, teor médio de acidez e com excelentes características plásticas e boa elasticidade, sendo capaz de filar sem problemas (ponto ideal de filagem).

-Paracaseína: Massa com desmineralização avançada, alto teor de acidez; se aquecida, não fila, apenas estica e se rompe, perdendo também a capacidade de reter a gordura.

No Seminário Internacional sobre Pizza Cheese(1997), foram comentados 2 processos básicos que podem ser adotados para fermentação da massa: a) Processo tradicional, no qual a massa é deixada fermentar, após a dessoragem e pré-prensagem, na forma de blocos. Nesse caso, tem-se 3 opções: deixar os blocos fermentarem naturalmente à temperatura ambiente e depois filá-los; deixá-los fermentar em tanques 
com água quente, com posterior filagem ou, então, deixá-los fermentar até quase atingirem o $\mathrm{pH}$ de filagem, depois colocá-los em câmara fria, durante a noite, e filá-los no dia seguinte e b) Processo no qual a massa, após atingir o ponto, continua a ser agitada, no soro, ou na água quente, até atingir o ponto de filagem, sendo depois dessorada e filada.

\subsubsection{Filagem e moldagem}

Após a fermentação, os blocos de massa são picados e submetidos a operação de filagem, que pode ser tanto manual como mecânica. Essa operação consiste na imersão da massa em água quente, seguida de agitação própria, sendo que a medida que a massa se aquece, os pedaços da mesma se ligam formando um só bloco, o qual vai se tornando cada vez mais plástico e ao ser esticado forma fios longos (Kosikowski, 1970 e Oliveira, 1982).

Em condições normais, a filagem deve ser realizada quando a massa se apresenta moderadamente mineralizada, como paracaseinato monocálcico, situação esta que corresponde a um valor de $\mathrm{pH}$ entre 4,8-5,5(em média 5,1-5,2). Entretanto, a determinação do $\mathrm{pH}$ ideal de filagem é dificil, pois depende do teor inicial de cálcio do leite, sendo que quando esse teor de cálcio é elevado a massa tende a filar em um $\mathrm{pH}$ mais baixo (Furtado, 1997c e Kosikowski, 1958).

A temperatura da água de filagem varia de $75-85^{\circ} \mathrm{C}$ (Behmer, 1984 e Oliveira, 1982), sendo que a temperatura da massa não deve ultrapassar $58-60^{\circ} \mathrm{C}$, o que poderá provocar alterações na estrutura e composição do queijo (Seminário Internacional sobre Pizza Cheese, 1997). Temperaturas acima de $58-60^{\circ} \mathrm{C}$ promovem danificação celular no fermento, além de destruição quase total dos resíduos de coalho (Furtado, 1997c e McMahon et al.,1993).

A proporção entre água de filagem e massa varia segundo diferentes autores, sendo que Furtado(1997a) e Valle(1991) recomendam a proporção 2:1 e Sghedoni et al. 
(1979) e Souza (1985), a proporção 3:1. No entanto, a maioria dos trabalhos publicados sobre fabricação de Mussarela não fazem menção a proporção água/massa recomendada e nem ao tempo de trabalho da massa na água quente.

Segundo Vitagliano ${ }^{2}(1980)$, citado por Valle(1991), durante a filagem ocorre uma perda de constituintes do estrato seco da ordem de $4 \%$, principalmente de gordura e de proteína, os quais passam para a água de filagem, que assume um aspecto leitoso. Nessa operação a massa também tende a absorver água em cerca de 2-4\%(Furtado, 1997a ).

Após a filagem, a massa é moldada, sendo geralmente colocada em formas retangulares. Entretanto, essa massa também pode ser moldada de forma a assumir formatos variados, os quais conferem a Mussarela denominações típicas, tais como: Trança, nozinho, palito, cabacinha, entre outras (Oliveira \& Caruso, 1996 e Valle, 1991).

\subsubsection{Resfriamento}

Após 2 a 3 viragens na forma, com intervalos de 5-10 minutos, a Mussarela deve ser colocada em água gelada a temperatura de $8-10^{\circ} \mathrm{C}$, onde deve permanecer submersa por cerca de 45-90 minutos (Furtado \& Lourenço Neto, 1997a; Seminário Internacional sobre Pizza Cheese,1997 e Sghedoni et al.,1979).

Esse tratamento é necessário para evitar que a Mussarela entre quente na salmoura, o que resulta em deformação do queijo; maior transferência de gordura, da massa, para a salmoura ; deterioração mais rápida da salmoura e aquecimento da mesma, o que faz aumentar a absorção de sal na casca, com desidratação acentuada da mesma (Furtado, 1991).

\footnotetext{
${ }^{2}$ VITAGLIANO, P. La legge 2 febbraio 1939 e l'odierna produzione di formaggio a pasta filada. Riv.
} Soc. Ital. Sci. Alim., v.9, n.5, p.345-348, 1980. 


\subsubsection{Salga e secagem}

A operação de salga apresenta inúmeras funções, sendo que, em resumo, pode-se dizer que o sal participa no desenvolvimento do sabor, textura, no controle da umidade, da maturação e na conservação do produto (Oliveira, 1982 e Seminário Internacional sobre Pizza Cheese, 1997).

No caso da Mussarela, o sal exerce grande influência sobre as suas propriedades funcionais, sendo que quanto mais elevado o seu teor de sal, menor tenderá a ser a sua proteólise e maior será a emulsificação de gorduras, o que favorecerá a elasticidade e diminuirá o "oiling off", embora prejudique o derretimento e possa causar maior escurecimento, caso reduza a atividade do fermento (Furtado \& Lourenço Neto, 1997c e McMahon et al., 1993).

No Brasil, a Mussarela geralmente é salgada de modo a adquirir um teor de sal na faixa de 1,4-1,8\% (Del Prato, 1993; Furtado, 1991 e Oliveira, 1982), sendo que em outros países, como a Itália e a Alemanha, o teor médio de sal é da ordem de $1 \%$ (Oliveira, 1982 e Valle, 1991).

Atualmente existem 3 processos que podem ser adotados para a salga da Mussarela: salga em salmoura, salga a seco logo após a filagem e salga a seco um pouco antes da filagem. Esses 3 processos podem ser assim esquematizados (McMahon et al., 1993 e Seminário Internacional sobre Pizza Cheese, 1997):

- Massa fermentada $\rightarrow$ filagem $\rightarrow$ moldagem $\rightarrow$ resfriamento $\rightarrow$ salga em salmoura

- Massa fermentada $\rightarrow$ filagem $\rightarrow$ adição de sal $\rightarrow$ moldagem $\rightarrow$ resfriamento

- Massa fermentada $\rightarrow$ adição de sal $\rightarrow$ filagem $\rightarrow$ moldagem $\rightarrow$ resfriamento

(em salmoura com $3-4 \%$ de sal) 
O processo mais utilizado mundialmente é o da salga em salmoura, a qual tende a apresentar uma temperatura de $10-12^{\circ} \mathrm{C}$ e uma concentração de sal de $20-24 \%$ (Fox \& Guinee, 1987; Furtado \& Lourenço Neto, 1997a e Kosikowski, 1970).

No Brasil, a maioria absoluta das Mussarelas, feitas para utilização em pizzarias, se apresenta em formato retangular, com peso variando de 2,5-3,0 quilos, sendo salgada em salmoura com $20 \%$ de sal e temperatura de $10-12^{\circ} \mathrm{C}$, por cerca de 24 horas, o que the confere um teor de sal em torno de 1,6\% (Furtado, 1997a).

De acordo com Leake \& Nilson (1969a) e com o material apresentado no Seminário Internacional sobre Pizza Cheese (1997), o indicado seria trabalhar com salmouras mais concentradas e com temperaturas mais baixas, sendo que o ideal seria $o$ uso de uma salmoura a $-2^{\circ} \mathrm{C}$, pois quanto menor a temperatura, menor a perda de umidade e maior o rendimento.

Após a salga, a Mussarela deve passar por um processo de secagem, de preferência em câmara própria, com temperatura ajustada para $8-10^{\circ} \mathrm{C}$ e umidade de 80 85\%, por um período de, pelo menos, 24 horas (Furtado \& Lourenço Neto, 1997a). Terminada a secagem, a Mussarela deve ser acondicionada em material plástico e embalada a vácuo (Albuquerque \& Carvalho, 1997).

\subsubsection{Estabilização e comercialização}

A estabilização da Mussarela consiste em armazená-la, por um período mínimo de 8 e máximo de 20 dias, em câmara fria, com uma temperatura ajustada para $8-10^{\circ} \mathrm{C}$. Essa operação é feita porque, durante os primeiros dias após a sua manufatura, a Mussarela passa por grandes mudanças quanto a sua textura e propriedades de fusão(Furtado \& Lourenço Neto, 1997a).

$\mathrm{Na}$ Mussarela fresca a matriz protéica é mais rígida, o que faz com que o queijo submetido a aquecimento derreta mal, tenha menor elasticidade, endureça mais 
rapidamente, perdendo mais água e formando grânulos (Furtado, 1997a e McMahon et al.,1993).

Durante o chamado período de estabilização tem-se uma diminuição na quantidade de água livre presente na Mussarela, ou seja, ocorre um aumento na sua capacidade de retenção de água, o que melhora a moagem e o fatiamento (Seminário Internacional sobre Pizza Cheese, 1997). Além disso, nessa fase há uma proteólise gradual da caseína, melhorando o derretimento e a elasticidade do queijo, sem nenhum prejuízo para as características de escurecimento moderado ou separação mínima de gordura, durante o derretimento da pizza (Furtado \& Lourenço Neto, 1996).

Outra vantagem desse período de estabilização é que nele ocorre uma melhor distribuição do sal, no queijo. Na Mussarela fresca, salgada em salmoura, o teor de sal, na casca, é muito mais elevado do que no centro, sendo que após 2-3 semanas essa distribuição melhora, formando-se um gradiente linear de distribuição de sal (Farkey et al., 1991 e Kindstedt et al., 1992).

Após a estabilização, a Mussarela deve ser imediatamente comercializada, pois com o passar do tempo, devido a proteólise, ocorre uma perda de elasticidade no queijo derretido, além de escurecimento, derretimento e "oiling off" em níveis indesejáveis, o que compromete o seu uso em pizzarias. Assim, sob condições de refrigeração normais, há um período relativamente curto de aceitabilidade, de cerca de 3-4 semanas, durante o qual a Mussarela pode ser usada para pizza (Kindstedt, 1993a e McMahon et al., 1993).

\subsection{Rendimento econômico e técnico de queijos}

Quando se fala em rendimento, normalmente pensa-se na relação de litros de leite que foram necessários para elaborar um quilograma de um determinado tipo de queijo (Van Den Berg et al., 1996).

Segundo Furtado (1998a), dentro desse conceito, pode-se definir o controle de "litros por Kg" como um Rendimento Econômico, ou seja, aquele através do qual o 
empresário calcula o custo final da produção de seu queijo, levando-se em consideração o preço pago por um litro de leite e o volume deste necessário para produzir um quilo de queijo. O Rendimento Técnico, por outro lado, seria aquele no qual de posse de dados físico-químicos referentes a composição do leite, do soro resultante e do queijo obtido, o técnico ou o queijeiro determinariam se houve um aproveitamento ideal dos constituintes do leite que podem ser transferidos para o queijo. Além disso, permitiria estabelecer ainda comparações válidas entre diferentes fabricações de um mesmo tipo de queijo, mesmo que este apresentasse composição físico-química diferente.

Obviamente, o rendimento técnico pode alterar substancialmente o rendimento econômico de uma fabricação e influenciar decisivamente no custo final de um queijo e, em última instância, na sua competitividade no mercado.

Existem várias maneiras de se calcular o rendimento técnico através da determinação do aproveitamento de elementos do leite na coalhada, como a gordura, proteínas totais ou somente a caseína, extrato seco total ou desengordurado, etc. Os métodos mais simples baseiam-se na transferência da gordura e/ou do extrato seco total ou desengordurado, do leite para o queijo (Furtado, 1998a).

\subsection{Uso de leite em pó na fabricação de queijos}

\subsubsection{Sazonalidade da produção de leite no Brasil}

De acordo com Primo (1996), a sazonalidade da produção agrícola é um problema universal, onde as estações dão ritmo ao ciclo produtivo vegetal e animal de acordo com a influência climática à qual está exposta a produção agropecuária. Assim, os produtos atingem pico de produção em tempos favoráveis e desaparecem quando o tempo é adverso, ou seja, safra e entressafra, respectivamente. 
Ante essa situação, vários países trataram de implantar políticas econômicas, visando superar as limitações impostas pela natureza. Infelizmente, o Brasil ainda sofre uma marcante sazonalidade em relação a produtividade do rebanho leiteiro, principalmente em razão do atraso tecnológico em que se encontra boa parte da pecuária leiteira nacional.

Vieira (1981) sugere que uma medida, que poderia resolver em parte esse problema, seria a concentração e desidratação do leite excedente produzido na safra (outubro a março) e a sua reconstituição na entressafra, sendo que esse leite reconstituído poderia ser consumido diretamente ou então utilizado na fabricação de derivados lácteos, como de queijos, por exemplo.

Essa medida é também vantajosa se considerarmos que, no Brasil, as melhores regiões para a criação de gado situam-se relativamente longe dos grandes centros consumidores. Assim, considerável economia de transporte poderia ser conseguida se o leite fosse desidratado nas zonas de produção e reconstituído próximo aos centros de consumo (Vieira et al., 1982).

\subsubsection{Efeitos da secagem sobre o leite}

Durante o processo de secagem do leite, ocorre uma desnaturação das suas proteínas solúveis (proteínas do soro), por ação do calor (Vieira, 1979). Esse termo desnaturação pode ser explicado como um desdobramento da estrutura compacta da molécula de proteína para uma forma menos organizada. Nesse sentido ocorrem mudanças nas estruturas quaternária, terciária e secundária da proteína, resultando na exposição de grupos funcionais internos (Wolfschoon-Pombo et al., 1982). O grau de desnaturação das soroproteínas vai depender da duração e da intensidade do tratamento térmico sofrido pelo leite (Knipschildt, 1976).

Ao contrário das soroproteínas, as caseínas suportam bem o tratamento térmico, sendo que um aquecimento a $88^{\circ} \mathrm{C}$ durante 10 minutos não modifica o tamanho nem a 
composição das micelas de caseína (Moor, 1965). De acordo com Wolfschoon-Pombo (1984), as caseínas para sofrerem alterações precisam de temperaturas e tempos de aquecimento relativamente elevados, como por exemplo $120^{\circ} \mathrm{C} / 30$ minutos.

Vieira (1979) relata que um tratamento a $74^{\circ} \mathrm{C}$, durante 2 minutos, desnatura $10 \%$ das proteínas do soro, sendo que uma desnaturação total dessas proteinas é obtida após um aquecimento de 1 hora a $77^{\circ} \mathrm{C}$ ou de 30 minutos a $90^{\circ} \mathrm{C}$.

Como conseqüência da desnaturação as soroproteínas ( $\alpha$-lactoalbumina e $\beta$ lactoglobulina) tendem a formar associações e agregados entre si, bem como complexos com as caseínas, especialmente a k-caseína (Figura 8)

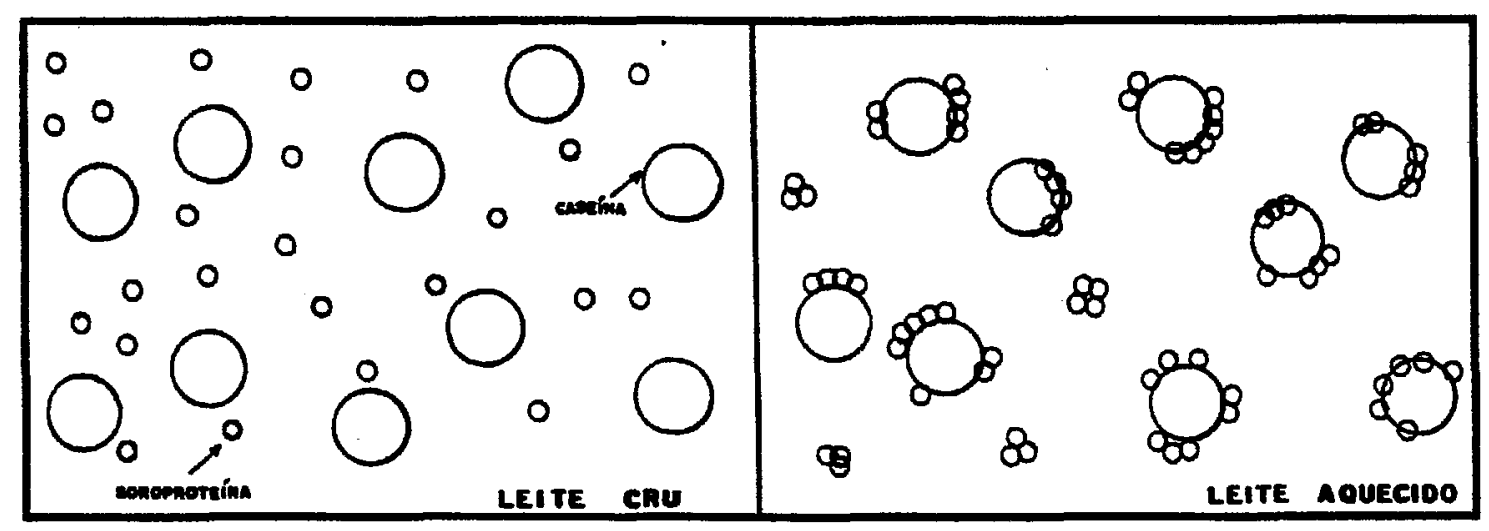

Figura 8: Representação das interações entre soroproteínas e caseínas no leite cru e aquecido (Wolfschoon-Pombo, 1984).

\subsubsection{Classificação do leite em pó}

A classificação do leite em pó, de acordo com o tipo de tratamento térmico recebido, não é uma exigência fundamental, mas é de grande importância prática na indicação da adequação de um leite em pó para uso na manufatura de queijos e de outros produtos lácteos. Assim, essa classificação é adotada há vários anos em países como a 
Austrália, Nova Zelândia e Estados Unidos. Entretanto, na maioria dos países, essa classificação não é realizada ( Covarrubias et al., 1988 e Knipschildt, 1976).

Essa classificação do leite em pó, quando realizada, é comumente feita com base na medição da quantidade de proteínas do soro, não desnaturadas, que sobram no pó, após o tratamento térmico. Esse nível de soroproteínas não desnaturadas, presente no pó, é indicado através do chamado índice de nitrogênio das soroproteínas, o qual é medido em miligrama de nitrogênio protéico solúvel não desnaturado por grama de leite em pó desnatado (Vieira \& Neves, 1980). Esse método tem sido divulgado pelo American Dry Milk Institute -ADMI (1971) e permite a classificação do leite em pó em 3 categorias: Pó "baixa temperatura" (índice maior ou igual a 6,0 mg/g), Pó "média temperatura" (índice maior que 1,5 e menor que $6,0 \mathrm{mg} / \mathrm{g}$ ) ou Pó "alta temperatura" (índice menor ou igual a $1,5 \mathrm{mg} / \mathrm{g})$.

\subsubsection{Especificações do leite em pó utilizado na fabricação de queijo}

As proteínas do soro, desnaturadas pelo calor, precipitam junto com as caseínas, durante o processo de coagulação do leite, o que normalmente não é desejável na fabricação de queijos. Consequentemente, o leite em pó mais indicado para manufatura de queijos é aquele que contém a menor porcentagem possível de proteínas do soro desnaturadas, ou seja, o leite em pó "baixa temperatura" (índice maior ou igual a 6,0 $\mathrm{mg} / \mathrm{g}$ ), preferencialmente com menos de um ano de fabricação, o qual apresenta as vantagens adicionais de conter mais cálcio ionizado e de não apresentar o "sabor cozido" característico do leite em pó obtido por meio de tratamentos térmicos severos ( Gilles et al., 1979; Knipschildt, 1976 e Zuraw, 1985).

Para a produção de queijos pode-se utilizar leite em pó desnatado (com um teor máximo de gordura de 1,25\% e uma umidade máxima de 4\%) ou integral. (Vieira, 1981 e Wolfschoon-Pombo, 1984). Entretanto, de acordo com Al-Tahiri (1987) e Sanderson (1979), o leite em pó mais indicado seria o desnatado, devido a sua maior estabilidade, o 
que evitaria o desenvolvimento de um flavour rançoso no produto. Sanderson (1979) relata que, em caso de uso de leite em pó integral, deve-se escolher um leite que obedeça alguns critérios, tais como: ser de classificação fina, secado por pulverização, ter menos de 9 meses de fabricação, teor de umidade máximo de 3\% e ser livre de sabores e odores estranhos, entre outros.

A preparação do leite reconstituído consiste em misturar água ao leite em pó integral ou desnatado visando estabelecer a relação água/extrato seco do produto original e a preparação do leite recombinado consiste em misturar água e vários constituintes do leite (em geral matéria gorda anidra -MGHA- e leite em pó desnatado), a fim de obter a relação matéria gorda/extrato seco desengordurado e a relação água/extrato seco, obtendo desta maneira um produto com características do leite in natura (Vieira, 1981).

As condições em que é feita essa reconstituição do leite também são de grande importância, sendo que no caso do leite em pó integral nota-se um aumento sensível da dispersibilidade do pó quando ele é misturado em água com temperatura entre $32^{\circ} \mathrm{C}$ a $38^{\circ} \mathrm{C}$ e submetido a uma agitação enérgica (Vieira et al., 1982). Segundo Al-Tahiri (1987), o uso de água fria, na reconstituição do leite, diminui a dispersibilidade do pó, pode provocar a formação de espuma na superficie e, em caso de leite em pó mais antigo, tem-se perda de solubilidade.

\subsubsection{Queijos produzidos com o uso de leite em pó}

\subsubsection{Tipos diversos}

Atualmente, segundo Saboya (1997), a literatura especializada tem muitos relatos a respeito da possibilidade de fabricação dos mais variados tipos de queijos com o uso de leite reconstituído ou recombinado. Há estudos com queijos brancos sem maturação (Queso blanco, Cottage), queijos moles com superficie coberta por fungo (Camembert), queijos de massa filada (Mussarela), queijos semi-cozidos prensados (Prato, Edam, 
Gouda, Cheddar, Danbo), queijos duros (Ras), queijos com crescimento interno de fungo, entre outros.

De acordo com Cherrey (1978), o processo de obtenção de queijos com o uso de leite reconstituído começou a ser estudado a partir de 1952, por produtores franceses. No caso dos franceses esse estudo se realizou devido a problemas comerciais: no inverno, com as baixas normais de produção de leite, certos industriais recebiam uma quantidade de leite insuficiente para suprir a demanda habitual do mercado, no tocante aos queijos de curta conservação (massa fresca e mole). Eles conseguiram remediar essa situação acrescentando regularmente ao produto de suas coletas in natura, pequenas quantidades de leite reconstituído.

Quando essas experiências de fabricação foram realizadas, a qualidade dos pós era ainda medíocre e por isso era dificil adicionar mais de $30 \%$ de leite reconstituído desnatado ao leite in natura sem diminuir a qualidade dos queijos produzidos. Entretanto, em 1957, começaram a ser feitas, na escola de Mamirolle, na França, as primeiras tentativas de fabricação de queijos com leite reconstituído utilizando um leite em pó selecionado. Isso permitiu, em 1959, colocar em prática um processo viável numa fábrica de queijo de massa prensada, no Oriente Médio. Esse primeiro êxito deu um novo impulso às pesquisas, fazendo com que esses pesquisadores franceses concluíssem que era possível fabricar qualquer tipo de queijo, com leite reconstituído, desde que se adaptasse o processo clássico de fabricação às características particulares do leite reconstituído e se utilizasse um leite em pó de qualidade (Cherrey, 1978).

Na Suécia (Joost \& Karlsson ${ }^{3}$, citados por Vieira \& Neves, 1980) e na Dinamarca (Knipschildt,1976), a utilização de leite reconstituído está em torno de 25\% (75 partes de leite in natura pasteurizado misturadas com 25 partes de leite reconstituído), enquanto que na França ( $C h e r r e y{ }^{4}$, citado por Vieira \& Neves, 1980) o leite em pó é adicionado

\footnotetext{
${ }^{3}$ JOOST, K.; KARLSSON, B. Utilisation de poudres de lait écremé en fromagerie. Leur influence sur la fabrication et sur le rendement en fromage. XIX Congress International de Laitière, vol. IF, 1974.

${ }^{4}$ CHERREY, G. Les laits reconstitués dans la fabrication des fromages. La Tecnnique Laitière, n.912, p.37-41, 1977.
} 
diretamente ao leite in-natura, a fim de padronizar o estrato seco desengordurado em torno de $9,5 \%$, produzindo desta forma um coágulo firme, um rendimento mais alto e uma normalização das condições de transformação, adequadas à mecanização da fábrica.

Thompson (1978) desenvolveu pesquisas sobre a possibilidade de produção de queijos a partir de leite em pó desnatado reconstituído, numa tentativa de aliviar o excedente do produto, nos Estados Unidos. A partir dessas pesquisas, queijos tipo Cottage, Colby, Cheddar e Mussarela foram produzidos.

Vieira (1979) produziu queijo tipo Camembert a partir de leite em pó reconstituído e matéria gorda anidra, através de ultrafiltração.

Gilles \& Lawrence (1981) relataram que queijos tipo Suiço, Gouda e Edam têm sido produzidos satisfatoriamente a partir de leite reconstituído.

Vieira (1981), através de trabalhos desenvolvidos no Departamento de Tecnologia de Alimentos, da Empresa de Pesquisa Agropecuária de Minas Gerais (EPAMIG-DTA/ILCT), demonstrou que é possível fabricar queijo tipo Prato a partir de leite in natura adicionado de até $30 \%$ de leite reconstituído e obter produtos de composição idêntica aos fabricados a partir de leite in natura. A qualidade organoléptica e a textura final, no fim da maturação, não apresentaram diferença apreciável comparadas aos queijos fabricados somente com leite fresco.

Ranas-Oliveros \& Dulay (1982), através de estudos, concluíram que queijos moles produzidos com leite de vaca in natura adicionado de 10 a $20 \%$ de leite desnatado reconstituído não apresentaram alteração de sabor, aroma, corpo, textura, coloração e aceitabilidade.

Hill et al. (1982), produziram queijo "Queso Blanco", de boa qualidade, utilizando leite recombinado com $3 \%$ de gordura e $15 \%$ de sólidos não gordurosos, o qual foi obtido a partir de leite em pó desnatado "baixa temperatura" e creme fresco (35\% de gordura). 
Zuraw et al. (1985) adaptaram uma metodologia para a fabricação de queijo Danbo utilizando leite in natura misturado com $50 \%$ de leite reconstituído. Nenhum problema de consistência, sabor ou aroma foram detectados.

Saboya (1997) relata que Queijos tipo Minas Frescal podem ser elaborados com a adição de até $40 \%$ de leite em pó integral "média temperatura", sem afetar as características físico-químicas, a aceitabilidade e a vida de prateleira do produto.

\subsubsection{Mussarela}

De acordo com Thompson (1978) e Flanagan et al.(1978), queijo Mussarela com umidade entre $46-50 \%$ e baixa gordura ( $18 \%$ ou menos) pode ser facilmente obtido utilizando leite em pó recombinado desde que as seguintes precauções sejam tomadas: uso de leite em pó desnatado "baixa temperatura" e elevação da temperatura de cozimento da coalhada para $42-45^{\circ} \mathrm{C}$, com aquecimento da mesma em soro por longos períodos (para obter um grau de umidade que confira bom corpo e fatiamento). Esses queijos foram avaliados por diversas empresas americanas que consideraram o flavour, a cor, o derretimento e a elasticidade dos produtos aceitáveis.

Em contraste, Gilles \& Lawrence (1981) observaram que as características de derretimento e elasticidade, da Mussarela feita com leite recombinado, foram prejudicadas durante todos os estágios de armazenamento.

Lelievre et al. (1990) produziram queijo Mussarela com leite em pó "baixa temperatura", água e gordura anidra, sendo esse leite recombinado homogeneizado sobre condições de baixa pressão $(400 \mathrm{KPa})$ e alta pressão $(6700 \mathrm{KPa})$. Esses pesquisadores verificaram que o uso de leite homogeneizado a baixa pressão produziu queijos com propriedades de elasticidade e derretimento aceitáveis, enquanto que o uso de leite submetido a uma alta pressão de homogeneização afetou desfavoravelmente as características de derretimento dos queijos, uma vez que alta pressão causa maiores danos à estrutura da proteína. 
Demott (1983), com base nas descobertas de Thompson (1978) e Flanagan et al. (1978), estudou o efeito da adição de leite recombinado, ao leite in natura, sobre o rendimento da Mussarela e concluiu que aumentando-se a porcentagem de leite recombinado utilizado na elaboração do queijo, aumentava-se o seu rendimento .

Leake e Nilson (1969b) também encontraram que fortificando leite parcialmente desnatado com vários níveis de leite em pó desnatado obtinha-se um maior rendimento na Mussarela. Entretanto, os leites que receberam teores muito elevados de sólidos exigiram um maior período de estabilização para desenvolvimento de flavor e de um adequado derretimento.

\subsubsection{Efeitos da utilização de leite em pó sobre a fabricação de queijos.}

O uso de leite recombinado ou reconstituído provoca alterações em algumas das propriedades de fabricação de queijos, ou seja, como resultado do processo de secagem, a que é submetido parte ou a totalidade do leite a ser utilizado, tem-se uma taxa de coagulação mais lenta do leite, redução na firmeza da coalhada, ligeira diminuição na taxa de sinérese da coalhada, durante a manufatura, e os queijos recém fabricados tendem a apresentar um ligeiro flavor de leite em pó ou de gordura anidra. Para compensar, queijos produzidos com o uso de leite em pó tendem a apresentar maiores rendimentos (Gilles \& Lawrence, 1981 e Jana \& Thakar, 1996).

\subsubsection{Coagulabilidade}

Quando o leite é submetido a temperaturas superiores a $100^{\circ} \mathrm{C}$, uma grande parte das suas soroproteínas desnaturam-se e se ligam as micelas de caseína. Como resultado dessa ligação, tem-se uma modificação na superficie das micelas, o que resulta em uma maior resistência das mesmas a ação das proteases ( em particular a quimosina) (Cheftel 
et al., 1989). Hooydonk et al. (1987) relataram que, em caso de completa desnaturação das proteínas do soro, cerca de $25 \%$ da k-caseína do leite torna-se inacessível à hidrólise.

De acordo com os autores acima, embora a ligação soroproteínas-k-caseína dificulte a hidrólise da k-caseína, o principal fator responsável pela baixa coagulabilidade dos leites recombinados é a diminuição da propriedade de agregação das micelas de caseína, que foram hidrolizadas pela renina, devido ao seu recobrimento pelas proteínas do soro.

Além disso, o uso do calor causa mudanças no equilíbrio mineral presente no leite, por meio da precipitação de fosfato de cálcio. Esses complexos formados apresentam menor solubilidade e uma capacidade de se ligar a caseína diferente daquela apresentada pelo fosfato de cálcio micelar ( Banks et al. ,1993).

Segundo Zoon (1993), trabalhos recentes mostram que a coagulabilidade poderia ser melhorada por meio da acidificação do leite e da adição de cloreto de cálcio ou sulfato de cálcio (às vezes acompanhado por ácido fosfórico).

Um trabalho baseado nessas informações foi desenvolvido por Gilles \& Lawrence (1981), os quais adicionando cerca de 20 gramas de cloreto de cálcio/ 100 litros de leite recombinado, diretamente no tanque de fabricação, conseguiram obter uma coalhada mais firme em um tempo normal de coagulação (30-40 minutos).

Zuraw et al. (1985) também obtivéram melhoria na coagulabilidade do queijo Danbo, produzido com o uso de leite em pó "baixa temperatura", adicionando ao leite reconstituído 1,5 mM de cálcio, ajustando seu $\mathrm{pH}$ a valores de 6,45-6,50 e mantendo esse leite reconstituído refrigerado a $5^{\circ} \mathrm{C}$ por 18 horas.

\subsubsection{Sinérese}

Queijos produzidos com leite recombinado apresentam uma ligeira redução na sua taxa de sinérese, durante a sua manufatura (Gilles \& Lawrence, 1981). Essa redução seria 
causada por 2 fatores: presença, no leite, de complexos soroproteínas-micela de caseína (principalmente $\beta$-lactoglobulina-K-caseína), os quais prejudicariam as interações micelamicela, que são responsáveis pela sinérese (Pearse et al., 1985) e menor concentração de cálcio ionizado, o que também afeta as interações micela-micela, prejudicando a expulsão do soro da coalhada, a qual passa a reter mais umidade do que a coalhada obtida de leite fresco (Gilles \& Lawrence, 1981).

A dessoragem pode ser melhorada, em parte, pela utilização de pó "baixa temperatura" ou "média temperatura", pelo enriquecimento do conteúdo de proteínas do leite através da adição de ultrafiltrado e/ou empregando-se temperaturas de coagulação e cozimento mais elevadas ( Mietton, 1988).

\subsubsection{Maturação e desenvolvimento de flavor}

O uso de leite em pó, na fabricação de queijos brancos frescos, os quais são consumidos cerca de 2 a 3 dias após a sua produção, não é recomendado, devido ao fato de que queijos recém fabricados tendem a apresentar um flavor de gordura anidra (Gilles \& Lawrence, 1981). Entretanto, queijo Fetta, de bom flavor, foi produzido a partir de leite em pó recombinado por Gilles (1974). Possivelmente, o fermento usado na elaboração desse queijo foi hábil para reduzir as peroxidases presentes no produto.

Flanagan et al. (1978) e Thompson (1978) observaram que queijo Mussarela, elaborado com o uso de leite em pó desnatado "baixa temperatura" e creme fresco, apresentou ausência de flavor típico de Mussarela.

Queijos Gouda, Ras e Domiati apresentaram processo de maturação e desenvolvimento de flavor mais lentos do que aqueles verificados em queijos feitos com leite fresco, sendo que a concentração de ácidos graxos livres ( em Domiati) e de substâncias nitrogenadas e aminoácidos ( em Gouda) foram menores quando esses queijos foram elaborados com leite recombinado (Jana e Thakar, 1996). 
Gilles \& Lawrence (1981), considerando que queijos feitos a partir de leite recombinado usualmente maturam mais lentamente e desenvolvem pouco flavor, recomendam o uso de culturas láticas como Streptococcus salivarius ssp thermophilus, Lactobacillus delbruekii ssp bulgaricus e, particularmente, Lactobacillus casei, em queijos duros, de modo a acelerar o desenvolvimento do flavor.

Além do uso de culturas láticas mais proteolíticas, diversos métodos tem sido adotados para acelerar a maturação de queijos, onde o desenvolvimento de flavor é mais lento. Como exemplos desses métodos tem-se: aumento do nível de coalho utilizado, adição de ácidos graxos livres, incorporação de lipases (em Domiati); adição de proteases neutras (em Saint-Paulin) e adição de lipases com ou sem adição de proteases (em Ras) (Jana e Thakar, 1996).

\subsubsection{4) Rendimento}

Durante a fabricação de queijos de leite de vaca, a maior parte da caseína e da gordura farão parte do produto final, enquanto que a maioria das soroproteínas (que representam cerca de $20 \%$ do total de proteínas do leite) serão perdidas no soro. A inclusão de parte dessas proteínas poderia aumentar consideravelmente (maior ou igual a 5\%) o rendimento dos queijos (Zoon, 1993). Três métodos podem ser utilizados para aumentar a porcentagem de soroproteínas no queijo: ultrafiltração do leite a ser utilizado na manufatura dos queijos; inclusão de agregados de proteínas do soro ao leite ou através do tratamento térmico de parte ou da totalidade do leite a ser utilizado (Banks et al., 1993; Van Den Berg et al., 1996 e Zoon, 1993).

Hammond (1972) encontrou que o uso de leite em pó desnatado, na fabricação de queijo Cottage, resultou em um aumento de mais de $10 \%$ no rendimento do mesmo.

Siapantas (1981), estudando o efeito da utilização de leite recombinado e concentrado por ultrafiltração na fabricação de queijo Feta (um dos queijos mais 
consumidos na Grécia), encontrou cerca de $30 \%$ de aumento no rendimento do queijo devido a incorporação de proteínas do soro e outros componentes.

Jana e Thakar (1996), pesquisando trabalhos de diversos autores, relataram que o uso de leite recombinado resultou em aumento no rendimento de queijos tipo Quarg, Ras e Domiati. Esse aumento foi substancial (cerca de 20-30\% em relação ao método tradicional) especialmente quando queijo tipo Domiati foi feito com o uso de leite reconstituído submetido ao processo de ultrafiltração.

Embora diversos autores relatem que o uso de leite em pó, na fabricação de queijos, resulta em um aumento no rendimento dos mesmos, Saboya (1997), trabalhando com queijos tipo Minas Frescal elaborados com 0, 10, 20 e 40\% de leite reconstituído, concluiu que embora haja uma tendência no aumento do rendimento, em gramas de sólidos totais/ litro de leite, com o aumento da quantidade de leite recombinado utilizada, este aumento não é estatisticamente significativo. Flanagan et al. (1978) obteve que queijo Cottage, elaborado com leite reconstituído, teve um rendimento inferior (14-15\% menor) ao do queijo Cottage elaborado com leite fresco. 


\section{MATERIAL E MÉTODOS}

Nesse experimento foram processados queijos Mussarela a partir de leite in natura e a partir da mistura de leite in natura com 10 e $20 \%$ de leite reconstituído. Esses processamentos foram realizados no Laboratório de Laticínios, do Departamento de Ciência e Tecnologia Agroindustrial, da Escola Superior de Agricultura 'Luiz de Queiroz"-ESALQ/USP.

\subsection{Material}

\subsubsection{Leite in natura}

Nos experimentos utilizou-se leite de vaca, tipo A, pasteurizado pelo processo HTST $\left(72^{\circ} \mathrm{C} / 15\right.$ segundos), fornecido pela Agropecuária Santa Cruz Ltda, situada no município de Piracicaba, São Paulo.

\subsubsection{Leite em pó}

Foi utilizado um leite em pó integral "média temperatura", proveniente da Nova Zelândia, fornecido pela importadora New Zealand Products (São Paulo). Esse leite apresentava a seguinte composição química: Umidade,2,8\%; Gordura,26,5\%; Proteína,28,0\%; Lactose,36,9\% e Minerais, $5,8 \%$. 


\subsubsection{Fermento lático}

O fermento lático utilizado foi o DVS TCC-20, composto de Streptococcus salivarius ssp thermophilus (40\%) e Lactobacillus helveticus (60\%), fornecido pela Chr. Hansen Ind. e Com. Ltda, situada em Valinhos (SP).

\subsubsection{Cloreto de cálcio}

O cloreto de cálcio foi utilizado na forma de solução aquosa, a $50 \%(\mathrm{p} / \mathrm{v})$.

\subsubsection{Coalho}

$\mathrm{O}$ agente de coagulação empregado foi o coalho em pó de origem bovina fornecido pela Chr. Hansen Ind. e Com. Ltda (Valinhos-SP).

\subsubsection{Cloreto de sódio}

O cloreto de sódio utilizado foi o sal comum, de granulação fina, da marca registrada Cisne.

\subsection{Métodos}

\subsubsection{Reconstituição do leite em pó}

Para cada bloco de produção preparou-se cerca de 3 litros de leite reconstituído. Esse leite foi obtido através da mistura de 372 gramas de pó em 2628 gramas de água filtrada, fervida e posteriormente resfriada a $45^{\circ} \mathrm{C}$. As quantidades de leite em pó e de água a serem utilizadas na mistura foram calculadas visando a obtenção de um leite integral reconstituído com $8,75 \%$ de sólidos não gordurosos. 
O leite em pó foi adicionado a água lentamente, sendo o processo de homogeneização manual, com o uso de uma escumadeira de aço inoxidável. Após completa dissolução do pó, a mistura foi deixada em repouso a $45^{\circ} \mathrm{C}$ por um período de 1 hora. Após esse período, o leite reconstituído foi filtrado em um filtro de tela de aço inoxidável, a fim de retirar as partículas insolúveis. Em seguida, o leite foi mantido sob refrigeração, a temperatura de $8 \pm 1{ }^{\circ} \mathrm{C}$, por cerca de 16 horas, para assegurar uma melhor estabilização do meio (Vieira e Neves, 1980).

\subsubsection{Fabricação dos queijos}

Em cada bloco foram feitos 3 processamentos de queijos: um apenas com leite in natura (Testemunha), um com leite in natura adicionado de $10 \%$ de leite reconstituído (Tratamento 1) e um com leite in natura adicionado de $20 \%$ de leite reconstituído (Tratamento 2), sendo esses processamentos iniciados sempre em um mesmo dia.

Para cada processamento foram utilizados 8 litros de leite (Testemunha: 8 litros de leite in natura, Tratamento 1: 7,2 litros de leite in natura adicionado de 0,8 litros de leite reconstituído e Tratamento 2: 6,4 litros de leite in natura adicionado de 1,6 litros de leite reconstituído), num total de 21,6 litros de leite in natura e 2,4 litros de leite reconstituído por bloco.

No momento da fabricação desses queijos, o leite reconstituído, que fora preparado anteriormente, foi misturado ao leite in natura, nas proporções previamente definidas, diretamente na cuba de fabricação dos queijos, a qual tinha capacidade de 10 litros. Em seguida, a mistura composta de 8 litros de leite foi homogeneizada e ajustada a temperatura de $35 \pm 1^{\circ} \mathrm{C}$, em banho-maria com temperatura controlada.

De cada cuba de fabricação, contendo 8 litros de leite, 200 mililitros de amostra foram retirados para a realização de análises físico-químicas, após a homogeneização e antes do aquecimento da mistura a $35 \pm 1{ }^{\circ} \mathrm{C}$. Portanto, cada queijo foi elaborado com o uso de 7,8 litros de leite. 
Quando o leite de cada tratamento atingiu a temperatura de coagulação $\left(35 \pm 1^{\circ} \mathrm{C}\right)$, foi acrescentado ao mesmo o fermento lático, na quantidade recomendada pelo fabricante. O leite foi, então, submetido a uma pré-maturação, por um período de 40 minutos, sendo mantido a $35 \pm 1^{\circ} \mathrm{C}$.

Terminada a fase de pré-maturação do leite, adicionou-se ao mesmo 0,4 mililitros de solução de $\mathrm{CaCl}_{2} 50 \%$ por litro, e, posteriormente, coalho em pó em uma quantidade suficiente para coagular a Testemunha em 50 minutos. Como a adição de leite reconstituído ao leite in natura resulta em uma mistura com uma taxa de coagulação mais lenta que a do leite fresco, os tempos de coagulação adotados (com base em testes preliminares) para o leite dos tratamentos 1 e 2 foram, respectivamente, de 55 e 60 minutos.

A coalhada obtida foi cortada, com liras horizontal e vertical, de modo a se obter cubos com 1 centímetro de aresta. Finalizado o corte, o coágulo foi deixado em repouso por 5 minutos, ao final dos quais a coalhada começou a ser agitada lentamente por um período de 10 minutos ("primeira mexedura").

Para intensificar a dessora desejada para a Mussarela, a temperatura de banhomaria foi elevada lentamente até $40^{\circ} \mathrm{C}$, sendo a coalhada agitada na cuba por mais 25 minutos ("segunda mexedura"), quando, então, atingiu o chamado ponto de massa. Atingido esse ponto, todo o soro foi eliminado.

Após o processo de dessoragem, a massa foi mantida na cuba, a temperatura de $40^{\circ} \mathrm{C}$, por um período de 1 hora, para acelerar o processo de acidificação da massa.

Devido a impossibilidade de elaborar, acidificar e filar as massas dos 3 tratamentos em um mesmo dia, as massas após fermentarem pelo período de 1 hora a $40^{\circ} \mathrm{C}$, foram mantidas sob refrigeração, a uma temperatura de $8 \pm 1^{\circ} \mathrm{C}$, por um período de 18 horas, afim de serem filadas no dia seguinte.

No dia seguinte ao do início da elaboração dos queijos, as massas foram retiradas da câmara fria, colocadas nas cubas de fabricação e novamente submetidas a uma 
temperatura de $40^{\circ} \mathrm{C}$, até atingirem um $\mathrm{pH}$ igual a 5,2 . Atingido esse $\mathrm{pH}$, as massas foram cortadas em fatias de cerca de 0,7 centímetros de espessura. As fatias foram, então, trabalhadas manualmente em água a temperatura de $78^{\circ} \mathrm{C}$, por um período de cerca de 5 minutos. Tomou-se o cuidado para que a massa trabalhada não atingisse temperatura superior a $58^{\circ} \mathrm{C}$, de modo a não prejudicar a atividade do coalho, nem do fermento láctico. A proporção utilizada de água de filagem/massa foi de 2:1.

A massa filada de cada tratamento foi cortada em 4 partes, as quais foram moldadas e colocadas em formas de plástico quadrangulares. As massas enformadas foram, então, deixadas em repouso por 10 minutos(com uma viragem após 5 minutos) e a seguir pesadas. Posteriormente essas formas foram imersas em água a temperatura de $8 \pm 1^{\circ} \mathrm{C}$, por 1 hora, a fim de promover o resfriamento da massa. A massa, após esse resfriamento inicial, foi colocada em salmoura, a temperatura de $8 \pm 1^{\circ} \mathrm{C}$, por 45 minutos.

A solução de salmoura utilizada tinha uma concentração de $20 \%$ e um pH igual a 5,3 , sendo utilizada na proporção de 3 litros de salmoura por quilo de queijo a ser salgado.

Após a salga, foi realizada a secagem dos queijos, em câmara fria, por um período de 24 horas. Concluída a secagem, as Mussarelas foram acondicionadas em sacos plásticos e mantidas sob refrigeração a uma temperatura de $8 \pm 1^{\circ} \mathrm{C}$.

\subsubsection{Análises físico-químicas do leite e do soro}

As amostras de leite foram coletadas após ter-se misturado ao leite in natura o leite reconstituído, antes de cada processamento, diretamente das cuba de fabricação de queijos, após ligeira homogeneização.

As amostras de soro também foram coletadas da cuba de fabricação dos queijos, após a retirada da massa e homogeneização do soro.

Todas as determinações foram realizadas em duplicata. 


\subsubsection{Densidade}

A densidade das amostras do leite e do soro foram determinadas por leitura direta a $15^{\circ} \mathrm{C}$, utilizando-se o termolactodensímetro de Quevenne, segundo LANARA (1981).

\subsubsection{2 pH}

$\mathrm{O} \mathrm{pH}$ do leite e do soro foi determinado em potenciômetro digital, com eletrodo de vidro da marca Digimed, modelo DMPH-2, previamente calibrado, segundo LANARA (1981).

\subsubsection{Acidez titulável}

A acidez do leite e do soro foi determinada através da titulação das amostras com solução de hidróxido de sódio $(\mathrm{NaOH}) \mathrm{N} / 9$ (solução Dornic), tendo como indicador a solução alcoólica de fenolftaleína a $1,0 \%$. Os resultados foram expressos em Graus Dornic ( $\left.{ }^{\circ} \mathrm{D}\right)$, segundo LANARA (1981).

\subsubsection{Gordura}

$\mathrm{O}$ teor de gordura do leite e do soro foi determinado pelo método de Babcock (Association of Official Analytical Chemists - A.O.A.C., 1995 e Newlander \& Atherton, 1964).

\subsubsection{Extrato seco total (EST)}

A porcentagem de extrato seco total do leite e do soro foi determinada de acordo com a metodologia descrita pela A.O.A.C. (1995), que se baseia na técnica de secagem em estufa a $105^{\circ} \mathrm{C}$ até peso constante. 


\subsubsection{Proteínas}

O teor de proteínas do leite e do soro foi determinado pelo Método Kjeldahl (técnica do micro Kjeldahl), segundo International Dairy Federation-IDF (1962).

\subsubsection{Desnaturação das proteínas de soro do leite}

A determinação da porcentagem de desnaturação das proteínas de soro do leite foram realizadas no leite in natura, na mistura de leite in natura com $10 \%$ de leite reconstituído e na mistura de leite in natura com $20 \%$ de leite reconstituído. Todas as amostras foram desnatadas em centrífuga (Fanem, modelo 204-NR), por 10 minutos a $4000 \mathrm{rpm}$.

As amostras de leite $(15 \mathrm{ml})$, após serem precipitadas na presença de 6 gramas de $\mathrm{NaCl}$, por meia hora em banho-maria a $37^{\circ} \mathrm{C}$, foram filtradas (papel Whatman $\mathrm{n}^{\circ} 42$ ). De cada filtrado foi retirado $1 \mathrm{ml}$, que foi diluído em $10 \mathrm{ml}$ de solução saturada de sal. Cada filtrado diluído recebeu a adição de 2 gotas de $\mathrm{HCl}(23 \mathrm{ml}$ de $\mathrm{HCl}$ concentrado $+77 \mathrm{ml}$ de água destilada), registrando-se, em seguida, a transmitância no comprimento de onda 420 nanômetros, conforme técnica descrita por Harland \& Ashworth (1947).

\subsubsection{Análises físico-químicas do queijo}

O início da fabricação dos 3 queijos (Testemunha, Tratamento 1 e Tratamento 2), de cada bloco de produção, ocorria sempre no mesmo dia. Como esses queijos eram deixados fermentar por 18 horas, a filagem e salga dos mesmos eram realizadas no dia seguinte. Desse modo, o processo de fabricação dos queijos desse experimento demorava 2 dias, sendo o dia do término da fabricação das Mussarelas chamado de Dia D. No dia D+1 os queijos eram submetidos a secagem e embalados, sendo as análises físicoquímicas dos mesmos feitas no dia $\mathrm{D}+2$, ou seja, 2 dias após o término da fabricação das Mussarelas. Essas análises foram sempre feitas em duplicata. 
As amostras dos queijos dos diferentes tratamentos foram retiradas e maceradas de acordo com as especificações de Silva et al.(1997).

Além das análises físico-químicas dos queijos, foi realizado também um acompanhamento da redução do $\mathrm{pH}$ das massas, após a dessoragem e durante o processo de fermentação das mesmas, até que fosse atingido o $\mathrm{pH}$ de filagem. Os valores de $\mathrm{pH}$ foram determinados em potenciômetro digital, com eletrodo de vidro da marca Digimed, modelo DMPH-2, previamente calibrado, segundo LANARA (1981).

\subsubsection{1 pH}

$\mathrm{O}$ pH dos queijos foi determinado em potenciômetro digital, com eletrodo de vidro da marca Digimed, modelo DMPH-2, previamente calibrado, segundo LANARA (1981).

\subsubsection{Gordura}

O teor de gordura das amostras de queijo foi determinado pelo método de Babcock (A.O.A.C., 1995 e Newlander \& Atherton, 1964).

\subsubsection{Gordura no extrato seco (GES)}

O teor de gordura no extrato seco (GES) do queijo foi calculado pela seguinte fórmula:

$$
\% \text { deGES }=\frac{\% \text { de gordura }}{\% \text { de extrato seco total }} \times 100
$$




\subsubsection{Umidade}

A determinação do teor de umidade dos queijos foi realizada segundo o método da A.O.A.C. (1995), baseado na técnica de secagem em estufa a $98-100^{\circ} \mathrm{C}$ até peso constante.

\subsubsection{Proteínas}

A porcentagem de proteínas dos queijos foi calculada multiplicando-se o valor médio de porcentagem de nitrogênio total dos mesmos pelo fator 6,38 . O teor de nitrogênio total (NT) das amostras de queijo foi determinado pelo método de Kjeldahl, diretamente sobre uma alíquota de $5 \mathrm{ml}$, extraída em citrato de sódio $0,5 \mathrm{M}$, segundo Gripon et al. (1975). As amostras foram digeridas em blocos digestores modelo TE008/50 e destiladas em destilador modelo TE-036.

\subsubsection{Teor de sal}

O teor de sal nos queijos foi determinado pelo método de Volhard, modificado por Pereira (1975).

\subsubsection{Teor de sal na fase aquosa}

O teor de sal na fase aquosa dos queijos foi calculado pela fórmula:

$$
\% \text { de sal na fase aquosa }=\frac{\% \text { de sal }}{\% \text { de sal }+\% \text { de umidade }} \times 100
$$




\subsubsection{Atividade de água (Aw)}

A atividade de água dos queijos foi determinada a partir da molalidade do cloreto de sódio $(\mathrm{NaCl})$, por meio da seguinte fórmula de Marcos et al. (1981):

$$
\begin{aligned}
\mathrm{Aw} & =1-0,033 \mathrm{M}, \text { onde: } \\
\mathrm{M} & =\left\{\left[(\mathrm{g} \mathrm{NaCl} \times 1000) \mathrm{g} \mathrm{H}_{2} \mathrm{O}\right] / 58,5\right\}
\end{aligned}
$$

\subsubsection{Cálculos de rendimento econômico e técnico}

O rendimento econômico dos queijos foi calculado através da seguinte fórmula:

$$
\text { Rend. Econ. }=\frac{\text { Litros de leite utilizados }}{\text { Quilos de queijo produzidos }} \times 100
$$

O rendimento técnico dos queijos foi determinado por 2 meios: através do índice denominado Rendimento Litros/Kg Ajustado (1/Kg A) e através do Coeficiente GL.

$\mathrm{O}$ índice Rendimento Litros/Kg Ajustado foi utilizado para calcular qual seria o rendimento dos queijos, dos diferentes tratamentos, se eles apresentassem um mesmo teor de umidade. De acordo com Furtado (1998a), esse índice é calculado por meio da seguinte fórmula:

$$
\text { Litros } / \text { Kg Ajustado }=\frac{\mathrm{V} \times(100-\mathrm{Up})}{\mathrm{P} \times \mathrm{ST}} \text { onde: }
$$

$\mathrm{V}=$ volume de leite (em litros)

$\mathrm{U}_{\mathrm{P}}=$ teor de umidade comum pretendida $\left(\mathrm{U}_{\mathrm{p}}\right.$ adotada $\left.=49,18 \%\right)$

$\mathrm{P}$ = produção de queijos (em quilos)

$\mathrm{ST}=$ teor de sólidos totais do queijo 
O método de determinação do rendimento através do Coeficiente GL é de simples aplicação e de grande eficiência e consiste em se determinar quanto de sólidos existe realmente num queijo já pronto e estabelecer uma relação com o volume de leite utilizado naquela fabricação. Sua simplicidade consiste na necessidade de se conhecer apenas os seguintes elementos para se efetuar os cálculos:

$$
\begin{aligned}
& \mathrm{ST}=\text { teor sólidos totais do queijo } \\
& \mathrm{P}=\text { produção de queijos (em quilos) } \\
& \mathrm{V}=\text { volume de leite (em litros) }
\end{aligned}
$$

Para se calcular gramas de sólidos totais por litro de leite trabalhado (g ST/1), relação conhecida por Coeficiente GL, a seguinte fórmula, deduzida por Furtado (1998a), foi aplicada:

$$
\mathrm{g} \mathrm{ST} / 1=\frac{\mathrm{ST} \times \mathrm{P} \times 10}{\mathrm{~V}}
$$

\subsubsection{Avaliação da propriedade de fatiamento}

Para essa avaliação fez-se uso de uma máquina de fatiar frios, a qual foi utilizada em 3 diferentes regulagens de corte, de modo a se obter fatias de Mussarela com 0,8;1,0 e $2,0 \mathrm{~mm}$ de espessura.

Os queijos foram avaliados quanto a essa propriedade após 2 semanas de armazenamento refrigerado a $8 \pm 1^{\circ} \mathrm{C}$.

\subsubsection{Proteólise}

As Mussarelas neste experimento tiveram sua atividade proteolítica avaliada com $2(\mathrm{D}+2), 12(\mathrm{D}+12)$ e $22(\mathrm{D}+22)$ dias de armazenamento refrigerado a $8 \pm 1^{\circ} \mathrm{C}$. A avaliação foi feita através dos índices de extensão e profundidade da proteólise, os quais 
foram calculados com base nos valores de nitrogênio total, nitrogênio solúvel a $\mathrm{pH} 4,6 \mathrm{e}$ nitrogênio não protéico solúvel em TCA $12 \%$ das amostras.

\subsubsection{Nitrogênio total (NT)}

O teor de NT dos queijos foi determinado pelo método de Kjeldahl, diretamente sobre uma alíquota de $5 \mathrm{ml}$, extraída em citrato de sódio $0,5 \mathrm{M}$, segundo Gripon et al. (1975). As amostras foram digeridas em blocos digestores modelo TE008/50 e destiladas em destilador modelo TE-036.

\subsubsection{Nitrogênio solúvel a pH 4,6 (NS)}

O teor de nitrogênio solúvel dos queijos foi determinado após precipitação isoelétrica das caseínas com solução de ácido clorídrico $1,41 \mathrm{~N}$ até $\mathrm{pH} 4,6$, em uma amostra de queijo, previamente solubilizada em citrato de sódio 0,5M. Essa mistura foi filtrada em papel Whatman $n^{\circ} 42$, coletando-se o filtrado contendo a fração hidrolisada da proteína do queijo, solúvel a pH 4,6. A quantificação dessas substâncias solúveis foi através do método de Kjeldahl, partindo-se de $5 \mathrm{ml}$ do filtrado (Vakaleris \& Price, 1959 e Gripon et al., 1975).

\subsubsection{Nitrogênio não protéico solúvel em TCA 12\% (NPN)}

As amostras de queijo previamente solubilizadas em citrato de sódio $0,5 \mathrm{M}$, foram precipitadas com solução de ácido tricloroacético 12\% (TCA) e filtradas em papel Whatman $\mathrm{n}^{\circ} 42$, coletando-se o filtrado, o qual continha peptídeos de baixo peso molecular e aminoácidos (Vakaleris \& Price, 1959). O nitrogênio contido nessa solução é denominado NPN e foi quantificado pelo método de Kjeldahl, partindo-se de $5 \mathrm{ml}$ do filtrado (Gripon et al., 1975). 


\subsubsection{4 Índice de extensão da proteólise}

Relação entre a porcentagem de nitrogênio solúvel a pH 4,6 e a porcentagem de nitrogênio total do queijo. Foi calculado por meio da seguinte fórmula, citada por Wolfschoon-Pombo (1983):

$$
\text { Extensão }=\frac{\text { Nitrogênio solúvel }}{\text { Nitrogênio total }} \times 100
$$

\subsubsection{5 Índice de profundidade da proteólise}

Relação entre a porcentagem de nitrogênio não protéico, solúvel em TCA 12\%, e a porcentagem de nitrogênio total do queijo. Foi calculado por meio da seguinte fórmula, citada por Wolfschoon-Pombo (1983):

$$
\text { Profundidade }=\frac{\text { Nitrogênio não protéico }}{\text { Nitrogênio total }} \times 100
$$

\subsubsection{Propriedades funcionais}

Os queijos também foram avaliados quanto as suas propriedades funcionais com 2, 12 e 22 dias de armazenamento refrigerado.

\subsubsection{Derretimento}

Para determinação da capacidade de derretimento da Mussarela foi retirada uma amostra cilíndrica dos queijos. Essa amostra cilindrica, retirada com o uso de uma sonda de $1 \mathrm{~cm}$ de diâmetro, apresentava uma área circular aproximada de $0,785 \mathrm{~cm}^{2}$ (A inicial) e foi cortada em discos com espessura de $0,5 \mathrm{~cm}$. De cada amostra, 3 discos foram 
separados ( um disco da superficie, um do centro e um da região intermediária entre o centro e a superficie da amostra) e colocados sobre um papel de filtro Whatman $n^{0} 42$.

O papel de filtro contendo os 3 discos foi introduzido numa estufa a $100^{\circ} \mathrm{C}$ por 15 minutos, binômio temperatura $x$ tempo utilizado por Arnott et al. (1957) para avaliação da propriedade de derretimento dos queijos.

Após os 15 minutos de aquecimento, os discos foram retirados, seus diâmetros medidos com régua e a partir do diâmetro médio obtido calculou-se a nova área, $\mathrm{em}^{2}$, do disco ( A derretida).

A porcentagem de derretimento foi, então, calculada pela seguinte fórmula:

$$
\% \text { Derretimento }=\frac{\text { A derretida }- \text { A inicial }}{\text { A inicial }} \times 100
$$

\subsubsection{Elasticidade}

$\mathrm{Na}$ avaliação dessa propriedade da Mussarela foram utilizadas 2 fatias de queijo de cada tratamento, apresentando as fatias $0,5 \mathrm{~cm}$ de espessura, $2,0 \mathrm{~cm}$ de largura e 4,0 $\mathrm{cm}$ de comprimento. Cada fatia foi colocada entre 2 torradas de $3,0 \mathrm{~cm}$ de largura por 5,0 $\mathrm{cm}$ de comprimento, as quais foram previamente cortadas ao meio.

As torradas contendo a fatia de queijo ("sanduíche") foram depositadas em um papel de filtro Whatman $\mathrm{n}^{\mathrm{o}} 42$ e colocadas em estufa a $100^{\circ} \mathrm{C}$ por 15 minutos, mesmo binômio temperatura $\mathrm{x}$ tempo usado para o teste de derretimento.

Após o derretimento, as 2 metades do "sanduíche" foram separadas, provocando um estiramento cada vez maior da Mussarela, a qual acabava por romper-se. Dado o rompimento, media-se, com régua, o comprimento do fio de Mussarela formado entre as 2 metades do "sanduíche". 


\subsubsection{Liberação de óleo livre}

O procedimento adotado para determinação da porcentagem de óleo livre, presente nos queijos derretidos, dos diferentes tratamentos, foi baseado no método de Babcock, descrito por Kindstedt \& Rippe (1990).

$\mathrm{Na}$ literatura, essa porcentagem de óleo livre é comumente expressa em relação a porcentagem total de gordura do queijo (OLGQ), através da seguinte fórmula:

$$
\% \text { de OLGQ }=\frac{\% \text { de óleo livre }}{\% \text { de gordura do queijo }}
$$

\subsubsection{Análise estatística}

Para análise estatística dos resultados foi adotado um delineamento experimental em Blocos ao Acaso, com 3 tratamentos ( Testemunha, 10 e $20 \%$ de leite reconstituído adicionado ao leite $n$ natura ) e 4 repetições ( blocos ). Os dados foram calculados utilizando o programa Sanest e avaliados através do Teste F da Análise da Variância e Teste Tukey (Pimentel-Gomes, 1985).

\begin{tabular}{lc}
\hline Causas de Variação & Graus de Liberdade \\
\hline Blocos & 3 \\
Tratamentos & 2 \\
Resíduo & 6 \\
\hline Total & 11 \\
\hline
\end{tabular}




\section{RESULTADOS E DISCUSSÃo}

\subsection{Composição físico-químicas do leite}

A Tabela 1 apresenta os valores médios, dos resultados obtidos, da composição fisico-química do leite in natura (Testemunha), do leite in natura adicionado de $10 \%$ de leite reconstituído (Tratamento 1) e do leite in natura adicionado de $20 \%$ de leite reconstituído (Tratamento 2), empregados na elaboração dos queijos.

Tabela 1. Valores médios das características fisico-químicas dos leites empregados na elaboração dos queijos.

\begin{tabular}{lcccc}
\hline \multicolumn{1}{c}{ Parâmetros } & Testemunha & Tratamento 1 & Tratamento 2 & C. V. \\
\hline Densidade (g/ml) & $1,0311^{\mathrm{a}}$ & $1,0312^{\mathrm{a}}$ & $1,0313^{\mathrm{a}}$ & 0,66 \\
PH & $6,79^{\mathrm{a}}$ & $6,82^{\mathrm{a}}$ & $6,84^{\mathrm{a}}$ & 1,18 \\
Acidez $\left({ }^{\circ} \mathrm{D}\right)$ & $16,87^{\mathrm{a}}$ & $17,07^{\mathrm{a}}$ & $17,55^{\mathrm{b}}$ & 0,77 \\
Gordura (\%) & $3,41^{\mathrm{a}}$ & $3,25^{\mathrm{a}}$ & $3,24^{\mathrm{a}}$ & 2,59 \\
Sólidos Totais (\%) & $11,65^{\mathrm{a}}$ & $11,82^{\mathrm{ab}}$ & $11,93^{\mathrm{b}}$ & 0,99 \\
Proteínas (\%) & $3,16^{\mathrm{a}}$ & $3,22^{\mathrm{ab}}$ & $3,27^{\mathrm{b}}$ & 1,16 \\
\hline
\end{tabular}

Médias de quatro fabricações. Médias seguidas por letras distintas a,b,c diferem entre si, ao nivel de $1 \%$ de significância. C.V.= Coeficiente de Variação.

As médias obtidas mostraram que aumentando-se a porcentagem de leite reconstituído, adicionado ao leite in natura, elevou-se a porcentagem de proteínas da mistura, bem como o seu teor de sólidos totais. 
As caseínas, que correspondem a cerca de $80 \%$ do total de proteínas do leite, são consideradas proteinas ácidas, por serem ricas em ácido glutâmico e aspártico (Cheftel et al., 1989). Desse modo, quanto maior o teor de proteínas de um leite, maior será a sua acidez titulável. Entretanto, esse aumento da acidez do leite, provocado pela adição de leite reconstituído ao leite in natura, também se deve provavelmente ao fato do leite reconstituído ser mais ácido, uma vez que ele contém uma maior porcentagem de proteínas desnaturadas, as quais tendem a apresentar um maior número de grupos ionizáveis (Gutierrez ${ }^{5}, 1998$ ).

No caso dos valores de $\mathrm{pH}$, não houve diferenças significativas porque a proteína é um ácido que se dissocia pouco. Sendo um ácido fraco, ela não altera tanto o valor da acidez potencial( soma da parte dissociada e não dissociada de um ácido) do leite, como altera o valor da sua acidez titulável (medida da parte dissociada de um ácido) (Gutierrez ${ }^{5}, 1998$ ).

Embora, em relação a alguns parâmetros, os tratamentos tenham diferido significativamente, constatou-se que os valores das características físico-químicas, dos diferentes tratamentos, estão dentro dos limites estabelecidos pela legislação (Brasil,1976 e 1998).

\subsection{Desnaturação protéica do leite}

O leite in natura, quando é pasteurizado, sofre uma desnaturação de parte das suas proteínas do soro, que são proteínas mais termolábeis. Essa desnaturação tende a ser maior quando o leite fresco é submetido a um processo de secagem visando a sua transformação em pó (Covarrubias et al., 1988 e Wolfschoon-Pombo et al., 1982). Desse modo, um leite pasteurizado sempre apresenta uma certa porcentagem de desnaturação de suas soroproteínas, sendo que essa porcentagem tende a aumentar, quanto maior for o

\footnotetext{
${ }^{5}$ GUTIERREZ, L.E. (ESALQ/ Departamento de Ciência e Tecnologia Agroindustrial). Informação
} Pessoal, 1998. 
teor de leite reconstituído adicionado a esse leite pasteurizado, como pode ser comprovado pelos resultados da Tabela 2 .

Tabela 2. Valores médios da porcentagem de desnaturação das proteínas do soro, dos leites empregados na elaboração dos queijos.

\begin{tabular}{ccccc}
\hline Parâmetro & Testemunha & Tratamento 1 & Tratamento 2 & C.V. \\
\hline $\begin{array}{c}\text { \% de desnaturação das } \\
\text { soroproteínas do leite }\end{array}$ & $4,72^{\mathrm{a}}$ & $10,56^{\mathrm{b}}$ & $17,51^{\mathrm{c}}$ & 12,25 \\
\hline
\end{tabular}

Médias de quatro fabricações. Médias seguidas por letras distintas ${ }^{\text {ab,c }}$ diferem entre si, ao nível de $1 \%$ de significância. C.V.= Coeficiente de Variação.

Essa desnaturação, embora acarrete algumas desvantagens no processamento (coagulação mais lenta do leite e redução da taxa de sinérese da coalhada, resultando em queijos mais úmidos) e nas características finais da Mussarela (pior fatiamento, derretimento e elasticidade) (Gilles \& Lawrence, 1981), não diminui o valor nutritivo da proteína láctea e hoje acredita-se que a proteína desnaturada seja melhor digerida, visto a melhor e maior exposição das cadeias peptídicas a ação de enzimas proteolíticas (Wolfschoon-Pombo et al., 1982).

\subsection{Pré-maturação do leite}

Uma pré-maturação do fermento no leite deve ser feita sempre que se trabalha com fermentos concentrados de uso direto (DVS), como o TCC-20, para permitir um pré ativação da cultura liofilizada no leite (Furtado, 1997a). Essa etapa deve durar de 30 a 40 minutos e resulta numa redução no tempo de manufatura e aumento no rendimento (com base na matéria seca) do queijo (Radke et al., 1979).

A Tabela 3 mostra os valores médios de $\mathrm{pH}$, dos leites utilizados no processamento dos queijos, após a pré-ativação do fermento. Esses valores não diferiram entre si ao nível de $1 \%$ de probabilidade, estando dentro dos limites encontrados $(6,58$ - 
6,67) em experimentos anteriores realizados com o TCC-20, em 20 fabricações efetuadas em 4 fábricas (Furtado \& Lourenço Neto, 1996).

Tabela 3. Valores médios de $\mathrm{pH}$ inicial do leite, do leite pré-maturado, da massa e do soro na dessoragem, dos 3 tratamentos avaliados.

\begin{tabular}{lcccc}
\hline \multicolumn{1}{c}{ Parâmetro } & Testemunha & Tratamento 1 & Tratamento 2 & C.V. \\
\hline Leite-inicial & $6,79^{\mathrm{a}}$ & $6,82^{\mathrm{a}}$ & $6,84^{\mathrm{a}}$ & 1,18 \\
Leite pré-maturado & $6,61^{\mathrm{a}}$ & $6,60^{\mathrm{a}}$ & $6,60^{\mathrm{a}}$ & 1,08 \\
Massa após dessoragem & $6,39^{\mathrm{a}}$ & $6,46^{\mathrm{a}}$ & $6,47^{\mathrm{a}}$ & 1,27 \\
Soro na dessoragem & $6,49^{\mathrm{a}}$ & $6,50^{\mathrm{a}}$ & $6,51^{\mathrm{a}}$ & 1,08 \\
\hline
\end{tabular}

Médias de quatro fabricações. Médias seguidas por letras distintas ${ }^{\text {a,b,c }}$ diferem entre si, ao nível de $1 \%$ de significância. C.V.= Coeficiente de Variação.

\subsection{Dessoragem}

Quando a coalhada atinge o seu ponto de massa, ou seja, atinge uma consistência tal que permite a obtenção de um produto final com um teor de umidade desejado, ela é dessorada (Oliveira, 1982). O valor de $\mathrm{pH}$, no qual o soro é removido, influencia a retenção de minerais na massa, especialmente do cálcio, e essa retenção mineral tem um grande impacto sobre a textura do queijo, o qual, por sua vez, afeta o derretimento e o fatiamento da Mussarela (Keller et al., 1974 e Lawrence et al., 1987). Portanto, o pH do soro, no momento da dessoragem, pode afetar a composição química e as propriedades funcionais da Mussarela (Kindstedt, 1993a).

Yun et al.(1995b) trabalhando com queijos Mussarela de baixa umidade e baixa gordura, produzidos sob as mesmas condições de processamento, mas apresentando um diferente $\mathrm{pH}$ do soro $(6,40$ e 6,15$)$, por ocasião da dessoragem, concluíram que quando a dessoragem era feita com o soro apresentando um valor de $\mathrm{pH}$ mais baixo, o queijo resultante apresentava menor nível de cálcio, maior teor de umidade e maior taxa de proteólise durante $o$ armazenamento refrigerado. 
Nesse experimento, as médias obtidas, para a massa e para o soro na dessoragem, nos 3 tratamentos, são apresentadas na Tabela 3. Os valores obtidos, com o uso do TCC20 foram próximos aos encontrados em experimentos anteriores, nos quais o $\mathrm{pH}$ do soro na dessoragem variava de 6,38-6,46 e o da massa, de 6,30-6,40 (Furtado \& Lourenço Neto, 1996).

$\mathrm{O}$ abaixamento do $\mathrm{pH}$, verificado no leite e posteriormente na massa (Tabela 3), ao longo do processo de fabricação dos queijos, foi resultante da degradação da lactose, pelas bactérias láticas, a qual levava a formação de ácido lático (Oliveira, 1982).

\subsection{Composição físico-química do soro}

O soro é um subproduto do processo de fabricação de queijos, sendo constituído principalmente por proteínas, gordura e sais minerais (Valle, 1991).

A Tabela 4 mostra que, com relação as características físico-químicas, os soros dos 3 tratamentos não diferiram entre si, ao nível de $1 \%$ de probabilidade.

Tabela 4. Valores médios das características físico-químicas dos soros obtidos na elaboração de queijos com 0,10 e $20 \%$ de leite reconstituído.

\begin{tabular}{lcccc}
\hline \multicolumn{1}{c}{ Parâmetro } & Testemunha & Tratamento 1 & Tratamento 2 & C.V. \\
\hline Densidade (g/ml) & $1,0270^{\mathrm{a}}$ & $1,0269^{\mathrm{a}}$ & $1,0268^{\mathrm{a}}$ & \\
Acidez $\left({ }^{\circ} \mathrm{D}\right)$ & $10,89^{\mathrm{a}}$ & $11,16^{\mathrm{a}}$ & $11,23^{\mathrm{a}}$ & 1,93 \\
Gordura (\%) & $0,46^{\mathrm{a}}$ & $0,44^{\mathrm{a}}$ & $0,46^{\mathrm{a}}$ & 8,21 \\
Sólidos Totais (\%) & $6,80^{\mathrm{a}}$ & $6,80^{\mathrm{a}}$ & $6,83^{\mathrm{a}}$ & 0,99 \\
Proteína (\%) & $1,07^{\mathrm{a}}$ & $1,04^{\mathrm{a}}$ & $1,04^{\mathrm{a}}$ & 1,77 \\
\hline
\end{tabular}

Médias de quatro fabricações. Médias seguidas por letras distintas ${ }^{\text {ab,c }}$ diferem entre si, ao nível de $1 \%$ de significância. C. V.= Coeficiente de Variação.

No caso das médias referentes a acidez titulável, embora não tenha ocorrido uma variação sensível entre os tratamentos, observou-se que aumentando a porcentagem de leite reconstituído, utilizado na elaboração dos queijos, elevava-se também a acidez do 
soro. Possivelmente a causa desse aumento foi o fato de que quanto mais elevada a porcentagem de leite reconstituído adicionada ao leite in natura, maior era o tempo de coagulação da mistura (Testemunha $=50$ ', Tratamento1 $=55^{\prime}$ e Tratamento2 $=60$ ') (Cheftel et al., 1989; Jana \& Thakar, 1996 e Zoon, 1993) e consequentemente maior se tornava o tempo de fermentação do produto até a dessoragem. Essa elevação da acidez titulável do soro deve-se também a maior acidez titulável observada no leite reconstituído (Tabela 1).

A composição média dos soros dos 3 tratamentos apresentaram valores semelhantes aos encontrados por Valle (1991) para soros obtidos de queijos elaborados apenas com o uso de leite in natura

\subsection{Fermentação e filagem da massa}

Na fabricação do queijo Mussarela, pelo processo tradicional, a fermentação da massa propicia as condições necessárias para a sua filagem, pois, na conversão da lactose em ácido lático, pela ação da cultura lática, consegue-se os níveis adequados de desmineralização, ou seja, a formação de paracaseinato monocálcico (Chapman \& Sharpe, 1981).

Empregando-se culturas termófilas, a massa pode ser filada no mesmo dia da sua fabricação, geralmente 4 a 6 horas após a adição do fermento (Furtado, 1991). Coppola et al. (1988); Del Prato (1993) e Valle (1991) trabalhando com essas culturas obtiveram massas em condições de serem filadas com cerca de 3 a 4 horas de fermentação(após a dessoragem) a uma temperatura de $38 \pm 2^{\circ} \mathrm{C}$.

Nos experimentos realizados, as massas dos 3 tratamentos demoraram cerca de 20 horas e 30 minutos para atingir um pH de filagem de 5,2 (Tabela 5). Entretanto, se essas massas não tivéssem sido armazenadas em câmara fria, por um período de 18 horas, provavelmente também teriam atingido seu $\mathrm{pH}$ de filagem em cerca de 3 a 4 horas.

Em relação aos diferentes tratamentos, não foram verificadas diferenças significativas entre eles, a nível de $1 \%$ de significância, em termos de evolução de acidez 
potencial das massas $(\mathrm{pH})$, como pode ser verificado pelos dados da Tabela 5 . Tais diferenças também não foram encontradas por outros pesquisadores (Gilles \& Lawrence, 1981 e Thompson, 1978) que trabalharam com Mussarela obtida com o uso de leite em pó.

Tabela 5. Valores médios de $\mathrm{pH}$ das massas, dos 3 tratamentos, durante o processo de fermentação.

\begin{tabular}{lcccc}
\hline \multicolumn{1}{c}{ Parâmetro } & Testemunha & Tratamento 1 & Tratamento 2 & C.V. \\
\hline Massa após dessoragem & $6,39^{\mathrm{a}}$ & $6,46^{\mathrm{a}}$ & $6,47^{\mathrm{a}}$ & $1,27^{\mathrm{a}}$ \\
$\begin{array}{l}\text { Massa após } 60 \mathrm{~min} \text { em } \\
\text { banho-maria a } 40^{\circ} \mathrm{C}\end{array}$ & $5,85^{\mathrm{a}}$ & $5,81^{\mathrm{a}}$ & $5,78^{\mathrm{a}}$ & $0,95^{\mathrm{a}}$ \\
$\begin{array}{l}\text { Massa após } 18 \mathrm{hs} \text { em } \\
\text { câmara fria a } 6-8^{\circ} \mathrm{C}\end{array}$ & $5,65^{\mathrm{a}}$ & $5,61^{\mathrm{a}}$ & $5,57^{\mathrm{a}}$ & $1,09^{\mathrm{a}}$ \\
$\begin{array}{l}\text { Massa após } 30 \mathrm{~min} \text { em } \\
\text { banho-maria a } 40^{\circ} \mathrm{C}\end{array}$ & $5,46^{\mathrm{a}}$ & $5,44^{\mathrm{a}}$ & $5,42^{\mathrm{a}}$ & $0,45^{\mathrm{a}}$ \\
$\begin{array}{l}\text { Massa após } 60 \mathrm{~min} \mathrm{em} \\
\text { banho-maria a } 40^{\circ} \mathrm{C}\end{array}$ & $5,30^{\mathrm{a}}$ & $5,31^{\mathrm{a}}$ & $5,31^{\mathrm{a}}$ & $0,45^{\mathrm{a}}$ \\
$\begin{array}{l}\text { Massa após } 90 \mathrm{~min} \text { em } \\
\text { banho-maria a } 40^{\circ} \mathrm{C}\end{array}$ & $5,20^{\mathrm{a}}$ & $5,20^{\mathrm{a}}$ & $5,20^{\mathrm{a}}$ & $0,22^{\mathrm{a}}$ \\
\hline
\end{tabular}

Médias de quatro fabricações. Médias seguidas por letras distintas ${ }^{\text {a,b,c }}$ diferem entre si, ao nível de $1 \%$ de significância. C.V.= Coeficiente de Variação.

Com relação a etapa de filagem, verificou-se que a mesma era prejudicada, a medida que aumentava-se a porcentagem de leite reconstituído utilizada na elaboração dos queijos.

De acordo com Valle (1991), durante a filagem, a estrutura granulosa e descontínua da massa é transformada em uma estrutura contínua e filamentosa. Porém, no caso da massa contendo $20 \%$ de leite reconstituído, essa transformação ocorria apenas 
parcialmente, o que resultava no rompimento da mesma, quando esticada. Esse problema praticamente não ocorria na massa com $10 \%$ de leite reconstituído.

Possivelmente a filagem da massa do Tratamento 2 era prejudicada devido a um maior número de complexos soroproteínas-micela de caseína, presente na mesma, o que alteraria o comportamento da matriz protéica, quando submetida a temperatura de filagem. Os trabalhos publicados sobre Mussarelas elaboradas com o uso de leite em pó não abordam as possíveis causas desse problema na filagem, o qual resulta em queijos com uma textura diferente daquela verificada em queijos elaborados apenas com o uso de leite in natura.

\subsection{Composição físico-química dos queijos}

A Tabela 6 mostra os resultados das análises fisico-químicas dos queijos elaborados apenas com leite in natura e com leite in natura adicionado de 10 e $20 \%$ de leite reconstituído, dois dias após a fabricação dos mesmos (D+2).

Tabela 6. Composição fisico-química dos queijos dois dias após a sua manufatura

\begin{tabular}{lcccc}
\hline \multicolumn{1}{c}{ Parâmetro } & Testemunha & Tratamento 1 & Tratamento 2 & C.V. \\
\hline PH & $5,36^{\mathrm{a}}$ & $5,36^{\mathrm{a}}$ & $5,43^{\mathrm{a}}$ & 0,65 \\
Gordura (\%) & $26,97^{\mathrm{a}}$ & $24,60^{\mathrm{ab}}$ & $23,35^{\mathrm{b}}$ & 3,80 \\
Umidade (\%) & $47,21^{\mathrm{a}}$ & $49,18^{\mathrm{b}}$ & $50,82^{\mathrm{c}}$ & 0,96 \\
GES (\%) & $51,11^{\mathrm{a}}$ & $48,41^{\mathrm{a}}$ & $47,50^{\mathrm{a}}$ & 3,47 \\
Proteína (\%) & $21,52^{\mathrm{a}}$ & $20,62^{\mathrm{a}}$ & $20,09^{\mathrm{a}}$ & 4,00 \\
Teor de Sal (\%) & $1,20^{\mathrm{a}}$ & $1,40^{\mathrm{ab}}$ & $1,62^{\mathrm{b}}$ & 1,40 \\
Teor de Sal-fase aquosa & $2,46^{\mathrm{a}}$ & $2,75^{\mathrm{ab}}$ & $3,09^{\mathrm{b}}$ & 6,11 \\
Aw & $0,990^{\mathrm{a}}$ & $0,983^{\mathrm{ab}}$ & $0,980^{\mathrm{b}}$ & 0,29 \\
\hline
\end{tabular}

Médias de quatro fabricações. Médias seguidas por letras distintas ${ }^{a b, c}$ diferem entre si, ao nível de $1 \%$ de significância. C.V.= Coeficiente de Variação. 
De acordo com Furtado (1991), nos Estados Unidos, a variação na maneira de consumir a Mussarela levou ao surgimento de 3 tipos básicos de produto, assim definidos: Mussarela para consumo direto regular (Composição média: 53,6\% de umidade, $18,0 \%$ de gordura, $38,8 \%$ de gordura no extrato seco, $22,1 \%$ de proteínas); Mussarela para consumo direto magra (Composição média: $57,2 \%$ de umidade, 13,5\% de gordura, $31,5 \%$ de gordura no extrato seco, $21,1 \%$ de proteínas) e Mussarela para pizza, a qual difere das demais pelo seu baixo teor de umidade, teor de gordura mais elevado, melhor capacidade de conservação e fácil fatiamento para a confecção de pizzas(Composição média: $47,0 \%$ de umidade, $23,7 \%$ de gordura, $44,7 \%$ de gordura no extrato seco, $25,0 \%$ de proteínas). Com base nesses dados de composição química, podese dizer que a Mussarela brasileira se assemelha a Mussarela para pizza americana, uma vez que a sua composição média é a seguinte: $43-48 \%$ de umidade, $22-24 \%$ de gordura e $40-45 \%$ de gordura no extrato seco(Furtado, 1997a).

No caso das Mussarela obtidas nesse experimento, as mesmas se encaixariam na Mussarela tipo pizza, em relação ao padrão americano.

Não foram observadas variações significativas nos valores de $\mathrm{pH}$ dos queijos dos diferentes tratamentos, sendo os valores encontrados semelhantes aos obtidos por Kindstedt et al. (1992) e Lee et al. (1980) em queijos Mussarela de baixa umidade parcialmente desnatados, dois dias após a sua fabricação.

A porcentagem de gordura desses queijos diminuiu, a medida que elevou-se a quantidade de leite reconstituído utilizada na elaboração das Mussarelas (Tabela 6). De acordo com Gilles \& Lawrence (1981), as perdas de gordura, durante a manufatura de queijos elaborados a partir da mistura de leite reconstituído com leite in natura, não serão maiores do que as observadas em queijos elaborados apenas a partir de leite in natura, desde que se realize uma eficiente homogeneização dessa mistura, permitindo a obtenção de uma emulsão estável. Como a homogeneização das misturas de leite reconstituído com leite in natura, utilizadas nesse experimento, foi apenas manual, possivelmente ocorreram 
maiores perdas durante o processamento desses queijos, o que justifica as menores porcentagens de gordura apresentadas pelos mesmos em relação a Testemunha.

Os teores de umidade dos queijos aumentaram significativamente a medida que elevou-se a porcentagem de leite reconstituído utilizada na fabricação dos mesmos(Tabela 6). Esse aumento ocorreu porque o leite reconstituído apresenta uma maior porcentagem de soroproteínas desnaturadas pelo calor, principalmente $\beta$ lactoglobulina, as quais formam complexos com a k-caseína, através de ligações dissulfeto (Pearse et al., 1985, Vieira, 1979 e Wolfschoon-Pombo, 1984). Esses complexos interferem com as interações micela- micela responsáveis pela sinérese da coalhada, provocando uma redução na mesma, o que resultaria em queijos com um maior teor de umidade ( Pearse et al., 1985; Pearse \& Mackinlay, 1989 e Wendorff, 1996).

Em conseqüência desse acréscimo de umidade, devido ao uso de leite reconstituído, os queijos dos tratamentos 1 e 2 não se situaram dentro da faixa de umidade ideal recomendada para Mussarela tipo pizza, a qual seria de 46-48\% de acordo com Furtado (1997a); Kindstedt et al. (1992); Kosikowski (1970) e Yun et al. (1995b).

Como a diminuição no teor de gordura dos queijos foi proporcionalmente maior do que a diminuição no teor de sólidos totais, a porcentagem de GES do Tratamento 2 foi menor do que a do Tratamento 1 , que por sua vez foi menor do que a da Testemunha (Tabela 6), embora, em termos estatísticos, os 3 tratamentos não tenham diferido significativamente.

Quanto ao teor de proteína, os tratamentos não diferiram entre si, ao nível de $1 \%$ de probabilidade, sendo que os valores encontrados para os 3 tratamentos (Tabela 6) foram semelhantes aos obtidos por Del Prato (1993) e Valle (1991) trabalhando com Mussarelas feitas sem o uso de leite em pó.

Em relação a porcentagem de sal que uma Mussarela deve apresentar, verificouse na literatura, que Kosikowski (1970) produziu queijo Mussarela, para pizza, a partir de leite in natura, com 1\% de sal, Kindstedt et al. (1992) com 1,25\% e Yun et al. (1995b) com $1,5 \%$. $O$ teor de sal desses queijos, no mercado brasileiro, na década de 70 , variava 
de 0,2 a $2,2 \%$ (Schiftan \& Komatsu, 1979), sendo que atualmente ele tende a se encontrar na faixa de 1,4 a 1,8\% (Furtado, 1997a). No mercado americano, por sua vez, tem-se verificado que em queijos Mussarela comerciais o teor de sal tem variado de 0,8 a 3,3\% (Kindstedt, 1993b).

Assim, como os teores de sal encontrados na Mussarela apresentam ampla variação, pode-se dizer que os teores de sal obtidos para os queijos dos 3 diferentes tratamentos não fugiram dos limites observados na literatura. Porém, os valores dos tratamentos variaram significativamente entre si, sendo que quanto mais leite reconstituído tinha o queijo, em sua composição, maior era o teor de sal apresentado por ele, fato que também foi observado por Wendorff (1996) trabalhando com queijos elaborados com o uso de leite em pó.

Essa maior absorção de sal, por queijos contendo leite reconstituído, pode ser explicada da seguinte forma: Quanto mais acentuada for a utilização de leite reconstituído, na elaboração de um queijo, maior será o seu teor de umidade (Pearse et al., 1985 e Wendorff, 1996) e quanto maior esse teor de umidade, mais rapidamente ele absorverá o sal durante o processo de salga (Furtado, 1991 e Lee et al., 1980). Como os queijos dos 3 tratamentos ficaram por um mesmo período na salmoura, era esperado que os queijos mais úmidos fossem os mais salgados, como pode ser verificado pelos dados da Tabela 6.

Esses resultados, entretanto, não se devem somente a umidade, mas também a influência desta na estrutura do queijo, sendo que quanto mais seco o queijo, mais compacta s sua estrutura, levando a uma salga mais lenta. Além disso, queijos com maior teor de GES (Tabela 6), como é o caso do queijo feito apenas com leite in natura, absorvem sal mais lentamente, provavelmente devido a modificações estruturais provocadas pela gordura, como a diminuição da capacidade de difusão do sal no queijo (Furtado, 1991).

O aumento ocorrido nos teores de sal foi proporcionalmente maior do que o aumento verificado nos teores de umidade das Mussarelas (Tabela 6). Consequentemente 
as porcentagens de sal na fase aquosa dos queijos também tenderam a elevar-se a medida que quantidades maiores de leite reconstituído eram empregadas no processo de fabricação das Mussarelas.

$\mathrm{Na}$ maioria dos queijos com um nível de umidade acima de $40 \%$ (caso do queijo Mussarela), a atividade de água dos mesmos pode ser determinada, com elevada precisão, a partir da molalidade do cloreto de sódio $(\mathrm{NaCl})$, por meio da seguinte fórmula: $\mathrm{Aw}=1-0,033 \mathrm{M}$, onde $\mathrm{M}=\left\{\left[(\mathrm{g} \mathrm{NaCl} \times 1000) / \mathrm{g} \mathrm{H}_{2} \mathrm{O}\right] / 58,5\right\}$ (Marcos et al.,1981). Desse modo, quanto maior o teor de sal na fase aquosa de um queijo, menor será a sua Aw (Guinee \& Fox, 1987 e Marcos et al., 1981), como pode ser comprovado pelos dados da Tabela 6.

Como os tratamentos diferiram significativamente entre si, quanto aos valores apresentados de $\mathrm{Aw}$, pode-se esperar que os 3 tratamentos apresentem também uma intensidade de maturação diferenciada, uma vez que a Aw é um dos parâmetros que mais afeta o crescimento da flora microbiana e os processos bioquímicos da maturação dos queijos (Furtado, 1991). Pequenas reduções na $\mathrm{Aw}$ de um queijo reduzem acentuadamente a atividade enzímica nos mesmos, além de alongar a fase de latência dos microorganismos e reduzir seletivamente sua taxa de crescimento, resultando em queda na atividade proteolítica nos queijos (Choisy et al., 1986 e Lawrence et al., 1987).

\subsection{Rendimento dos queijos}

Analisando-se os dados da primeira linha da Tabela 7 verifica-se que embora os queijos dos 3 tratamentos tenham apresentado um rendimento econômico superior ao rendimento médio normal esperado para o queijo Mussarela, que é de 9,5 a $10,51 / \mathrm{Kg}$ (Furtado, 1997a), o queijo do Tratamento 2 foi o que apresentou o melhor resultado. 
Tabela 7. Meios de expressão do rendimento dos queijos elaborados com 0,10 e $20 \%$ de leite reconstituído.

\begin{tabular}{ccccc}
\hline Parâmetro & Testemunha & Tratamento 1 & Tratamento 2 & C.V \\
\hline $\begin{array}{c}\text { Rendimento Econômico } \\
\left(1_{\text {leite }} / \mathrm{Kg}_{\text {queijo }}\right)\end{array}$ & $9,36^{\mathrm{a}}$ & $8,55^{\mathrm{b}}$ & $8,03^{\mathrm{c}}$ & 1,17 \\
$\begin{array}{c}\text { Rendimento Técnico } \\
\left(\mathrm{l}_{\text {leite }} / \mathrm{Kg}_{\text {queijo }} \text { Ajustado }\right)\end{array}$ & $9,01^{\mathrm{a}}$ & $8,55^{\mathrm{ab}}$ & $8,29^{\mathrm{b}}$ & 1,71 \\
$\begin{array}{c}\text { Rendimento Técnico } \\
\left(\mathrm{gST}_{\text {queijo }} / \mathrm{l}_{\text {leite }}\right)\end{array}$ & $56,49^{\mathrm{a}}$ & $59,47^{\mathrm{a}}$ & $61,29^{\mathrm{b}}$ & 1,53 \\
\hline
\end{tabular}

Médias de quatro fabricações. Médias seguidas por letras distintas ${ }^{\text {ab,c }}$ diferem entre si, ao nível de $1 \%$ de significância. $\mathrm{C} . \mathrm{V} .=$ Coeficiente de Variação.

Como esse maior rendimento comercial dos queijos feitos com o uso de leite reconstituído poderia ser atribuído a um maior teor de umidade dos mesmos (Tabela 6), foi calculado também o índice denominado Rendimento $1_{1 \text { eite }} / \mathrm{Kg}_{\text {queijo }}$ Ajustado, o qual avalia o rendimento dos queijos adotando um valor de umidade comum $(\mathrm{Up}=49,18 \%)$ para os diferentes tratamentos (Furtado, 1998). Os valores desse índice (Tabela 7) excluíram, porém, a possibilidade de que o maior rendimento apresentado pelos Tratamentos 1 e 2 fosse devido ao maior teor de umidade dos mesmos, em relação a Testemunha (Tabela 6).

Assim, o maior rendimento comercial, verificado nos queijos fabricados com o uso de leite reconstituído, se deve ao fato de que a adição de leite reconstituído ao leite in natura aumenta a porcentagem de soroproteínas, desnaturadas pelo calor, retidas na coalhada (Demott, 1983; Gilles \& Lawrence, 1981; Jana \& Thakar, 1996; Van Den Berg et al., 1996 e Vieira, 1979), o que aumenta a eficiência do processo em termos de aproveitamento de sólidos totais do leite no queijo, em relação a cada litro de leite trabalhado (Tabela 7) (Furtado, 1998a). 


\subsection{Fatiamento}

A Mussarela, quando usada no preparo de pizzas ou para outros fins culinários, é geralmente fatiada ou moída. Embora na grande maioria dos paises a Mussarela para pizza seja moída (Seminário Internacional sobre Pizza Cheese, 1997 e Kindstedt, 1993b), no Brasil ela ainda é muito utilizada na forma fatiada.

Nos experimentos realizados verificou-se que as Mussarelas elaboradas, sem o uso de leite reconstituído, eram as que melhor fatiavam, sendo possível a obtenção de fatias com espessuras inferiores a $1 \mathrm{~mm}$. Por outro lado, Mussarelas com $20 \%$ de leite reconstituído apresentavam um fatiamento ruim, só sendo possível obter cortes com no mínimo $2 \mathrm{~mm}$ de espessura.

Mussarelas com $10 \%$ de leite reconstituído apresentavam um comportamento intermediário, ou seja, fatiavam adequadamente desde que a máquina fosse regulada de modo a se conseguir fatias com $1 \mathrm{~mm}$ ou mais de espessura.

Queijos elaborados com o uso de leite reconstituído tendem a não apresentar um bom fatiamento e a "mascar" na máquina de fatiar porque contêm um maior teor de umidade (Tabela 6) ( Furtado, 1997a e Wendorff, 1996), sendo esse teor de umidade mais elevado resultante de uma menor sinérese da coalhada, provocada por uma maior porcentagem de soroproteínas ligadas a k-caseína (Pearse \& Mackinlay, 1989; Pearse et al., 1985 e Wendorff, 1996).

\subsection{Avaliação dos queijos durante o período de armazenamento refrigerado}

Considerando-se que geralmente numa pizza há uma variada mistura de ingredientes que fatalmente acabam por mascarar o sabor da Mussarela derretida sobre ela, pode-se dizer que as propriedades de derretimento, elasticidade, liberação de gordura e escurecimento não enzímico são os principais critérios utilizados na avaliação da 
qualidade de uma Mussarela para uso em pizzarias (Furtado, 1997a e Savage \& Mullan, 1996).

Portanto, a avaliação do $\mathrm{pH}$, da extensão e da profundidade da proteólise e das propriedades funcionais da Mussarela, durante o período de armazenamento refrigerado, são importantes para determinação do período de aceitabilidade desse queijo na elaboração de pizzas.

\subsubsection{Evolução do pH}

Não ocorreram diferenças significativas entre os valores de $\mathrm{pH}$ dos queijos elaborados com 0,10 e $20 \%$ de leite reconstituído, durante os 22 dias em que os mesmos foram mantidos sob armazenamento refrigerado (Tabela 8 ).

Tabela 8. Evolução do pH dos queijos, durante o período de armazenamento refrigerado.

\begin{tabular}{ccccc}
\hline Dia & Testemunha & Tratamento 1 & Tratamento 2 & C.V. \\
\hline D+2 & $5,36^{\mathrm{a}}$ & $5,36^{\mathrm{a}}$ & $5,43^{\mathrm{a}}$ & 0,65 \\
$\mathrm{D}+12$ & $5,44^{\mathrm{a}}$ & $5,46^{\mathrm{a}}$ & $5,61^{\mathrm{a}}$ & 1,82 \\
$\mathrm{D}+22$ & $5,50^{\mathrm{a}}$ & $5,53^{\mathrm{a}}$ & $5,78^{\mathrm{a}}$ & 2,25 \\
\hline
\end{tabular}

Médias de quatro fabricações. Médias seguidas por letras distintas ab,c diferem entre si, ao nível de $1 \%$ de significância. C.V.= Coeficiente de Variação.

Entretanto, os valores de $\mathrm{pH}$ dos queijos, dos 3 tratamentos, aumentaram no decorrer do período de armazenamento considerado.

De acordo com Notte et al (1980), os principais aminoácidos livres encontrados em queijos Mussarela, obtidos pelo processo tradicional, durante 16 dias de armazenamento refrigerado foram: lisina, histidina, ornitina, valina, alanina, prolina e ácido glutâmico. Sendo os aminoácidos lisina, histidina e ornitina classificados como 
básicos (Gutierrez, 1991) e sendo o ácido glutâmico livre (classificado como aminoácido ácido) encontrado em pequenas concentrações em queijos Mussarela (Paquet and Kalab, 1988), esse aumento nos valores de $\mathrm{pH}$ dos queijos, durante o armazenamento refrigerado, era esperado.

\subsubsection{Extensão da proteólise}

Os dados da Tabela 9 mostram que os 3 tratamentos não diferiram entre si, ao nível de $1 \%$ de probabilidade, durante as 3 semanas de armazenamento. Entretanto, observou-se que a medida que se acrescentava leite reconstituído na elaboração dos queijos, a extensão da proteólise diminuía ligeiramente. Esse fato ocorria porque os queijos do Tratamento 2 continham um teor de sal na fase aquosa maior do que os queijos do Tratamento 1, os quais, por sua vez, tinham um teor mais elevado do que os queijos utilizados como Testemunha. Quanto maior o teor de sal na fase aquosa de um queijo, menor tende a ser a sua atividade de água e, consequentemente, mais lenta a sua proteólise (Choisy et al., 1986; Guinee \& Fox, 1984; Lawrence at al, 1987 e Marcos et al., 1981)

Tabela 9. Extensão da proteólise dos queijos, durante o armazenamento refrigerado.

\begin{tabular}{ccccc}
\hline Dia & Testemunha & Tratamento 1 & Tratamento 2 & C.V. \\
\hline D+2 & $6,29^{\mathrm{a}}$ & $6,25^{\mathrm{a}}$ & $6,20^{\mathrm{a}}$ & 4,35 \\
D+12 & $9,18^{\mathrm{a}}$ & $8,91^{\mathrm{a}}$ & $8,70^{\mathrm{a}}$ & 6,67 \\
D+22 & $10,63^{\mathrm{a}}$ & $10,41^{\mathrm{a}}$ & $9,83^{\mathrm{a}}$ & 7,09 \\
\hline
\end{tabular}

Médias de quatro fabricações. Médias seguidas por letras distintas ${ }^{\text {a,b,c }}$ diferem entre si, ao nível de $1 \%$ de significância. C.V.= Coeficiente de Variação.

Uma outra informação que deve ser considerada na análise desses dados é que queijos que apresentam leite reconstituído em sua composição podem apresentar um 
índice de extensão da proteólise ligeiramente superestimado. Esse erro de estimativa ocorre porque as soroproteínas presentes no leite reconstituído não se precipitam junto com a caseína, durante o processo de extração do nitrogênio solúvel a pH 4,6 (Furtado \& Partridge, 1988). Consequentemente, a porcentagem de nitrogênio solúvel do queijo será dada em função da soma dos seus teores de peptídeos, aminoácidos e de soroproteínas, as quais não são hidrolizadas (Wolfschoon-Pombo, 1983). Portanto, para se determinar, com certeza, a extensão da proteólise, dos queijos elaborados com o uso de leite reconstituído, seria necessário saber a contribuição das soroproteínas no teor total de substâncias nitrogenadas solúveis acumuladas durante o período de estocagem do produto (Furtado \& Partridge, 1988).

Durante o armazenamento refrigerado, os queijos de todos os tratamentos sofreram aumentos nos seus índices de extensão da proteólise, como resultado do processo de degradação da caseína, por meio da ação de enzimas (Wolfschoon-Pombo \& Lima, 1989). Esse aumento, porém, foi mais acentuado nas duas primeiras semanas de estocagem. Segundo Lawrence et al.(1987) e Yun et al. (1993), isso ocorre porque durante um período de cerca de duas semanas, após a sua fabricação, a mussarela sofre uma intensa hidrólise da $\alpha_{s 1}$-caseína, via ação da quimosina. Após esse período, embora a atividade proteolítica das enzimas continue, ela tende a se tornar mais lenta (Lawrence et al., 1987).

Os valores médios de extensão da proteólise, obtidos nas 3 datas de análise, foram inferiores aos encontrados por Yun et al. (1993) em queijos Mussarela, elaborados com leite in natura, analisados durante um período de 50 dias de armazenamento refrigerado $(8,10 ; 13,20$ e 16,60$)$.

\subsubsection{Profundidade da proteólise}

A Tabela 10 mostra que os valores dos índices de profundidade da proteólise nos queijos, dos diferentes tratamentos, aumentaram durante as 3 semanas de estocagem. 
Esse aumento era esperado considerando-se que, durante o processamento dos queijos, evitou-se a adoção de medidas que pudessem prejudicar a atividade do fermento lático, cujas enzimas são as principais responsáveis pela obtenção de nitrogênio não protéico (Wolfschoon-Pombo \& Lima, 1989).

Tabela 10. Profundidade da proteólise dos queijos, durante o armazenamento refrigerado.

\begin{tabular}{ccccc}
\hline Dia & Testemunha & Tratamento 1 & Tratamento 2 & C.V. \\
\hline $\mathrm{D}+2$ & $3,01^{\mathrm{a}}$ & $2,98^{\mathrm{a}}$ & $2,94^{\mathrm{a}}$ & 9,36 \\
$\mathrm{D}+12$ & $3,73^{\mathrm{a}}$ & $3,51^{\mathrm{a}}$ & $3,48^{\mathrm{a}}$ & 9,06 \\
$\mathrm{D}+22$ & $4,56^{\mathrm{a}}$ & $4,23^{\mathrm{a}}$ & $3,90^{\mathrm{a}}$ & 8,39 \\
\hline
\end{tabular}

Médias de quatro fabricações. Médias seguidas por letras distintas ${ }^{\text {ab,c }}$ diferem entre si, ao nível de $1 \%$ de significância. C.V.= Coeficiente de Variação.

No caso desse índice de avaliação da proteólise também pode-se notar que, embora os valores dos tratamentos não tenham diferido em termos estatísticos, a medida que o teor de sal na fase aquosa do queijo aumentava (Tabela 6), a sua profundidade de proteólise diminuía. Isso ocorre porque elevando-se o teor de sal na fase aquosa de um queijo, diminuí-se sua atividade de água (Guinee \& Fox, 1987 e Marcos et al., 1991) e essa diminuição é prejudicial para a atividade das bactérias láticas.

\subsubsection{Derretimento}

Quanto maior o período de estocagem da Mussarela, melhor será o seu derretimento, pois maior terá sido a sua proteólise (Furtado \& Lourenço Neto, 1997c). Desse modo, a Mussarela recém fabricada é sempre mais dura e pouco solubilizada (borrachenta), apresentando dificuldades para o derretimento (Furtado, 1997a ), como pode ser comprovado pelos dados da Tabela 11. 
Tabela 11. Porcentagens médias de derretimento dos queijos.

\begin{tabular}{ccccc}
\hline Dia & Testemunha & Tratamento 1 & Tratamento 2 & C.V. \\
\hline $\mathrm{D}+2$ & $2,86^{\mathrm{a}}$ & $2,65^{\mathrm{a}}$ & $2,59^{\mathrm{a}}$ & 8,72 \\
$\mathrm{D}+12$ & $31,43^{\mathrm{a}}$ & $18,61^{\mathrm{ab}}$ & $11,55^{\mathrm{b}}$ & 9,76 \\
$\mathrm{D}+22$ & $32,31^{\mathrm{a}}$ & $19,43^{\mathrm{ab}}$ & $12,62^{\mathrm{b}}$ & 10,28 \\
\hline
\end{tabular}

Médias de quatro fabricações. Médias seguidas por letras distintas ${ }^{\text {a,b,c }}$ diferem entre si, ao nível de $1 \%$ de significância. C.V.= Coeficiente de Variação.

Após 12 dias de armazenamento refrigerado, começaram a ocorrer diferenças significativas entre as porcentagens de derretimento dos queijos, dos diferentes tratamentos (Tabela 11). Essas diferenças ocorreram porque a capacidade de derretimento da mussarela é influenciada por fatores como: porcentagem de gordura nos queijos (McMahon, 1993 e Tunick, 1991), porcentagem de sal (Furtado, 1997c e Kindstedt, 1991) e intensidade da proteólise nos mesmos (Oberg et al., 1991b e Yun et al., 1991). Como o aumento na porcentagem de leite reconstituído, na fabricação da mussarela, diminuía o seu teor de gordura, elevava o seu teor de sal e reduzia a sua proteólise (Tabela 6), era esperado que provocasse também uma diminuição no derretimento do queijo.

De acordo com Kindstedt (1993b), como a propriedade de derretimento da mussarela é influenciada por inúmeros fatores físico-químicos, queijos pertencentes a uma mesma categoria podem responder diferentemente a um mesmo binômio tempo $\mathrm{x}$ temperatura de aquecimento. Portanto, torna-se dificil comparar os resultados da Tabela 11 com os de outros autores que usaram diferentes condições de teste, só sendo possível verificar que neste, assim como em outros experimentos (Yun et al., 1993 e Yun et al., 1995), o aumento na porcentagem de derretimento foi mais acentuado nas duas primeiras semanas de estocagem. 


\subsubsection{Elasticidade}

O principal fator que afeta a elasticidade de um queijo é a proteólise. Mussarela recém fabricada possui um alto teor de caseína intacta, não apresentando boas condições de elasticidade (Furtado \& Lourenço Neto, 1993c e McMahon et al., 1993). Com o aumento gradual na degradação da matriz protéica, a capacidade de esticar-se da Mussarela derretida melhora, como pode ser comprovado pelos dados da Tabela 12, sendo que resultados práticos indicam que a massa atinge uma elasticidade ideal com cerca de 2 a 3 semanas de armazenamento refrigerado $\left(8-10^{\circ} \mathrm{C}\right.$ ) (Furtado, 1997a). A partir daí começa a haver uma perda progressiva da elasticidade da massa, a qual tende a romper-se facilmente, quando esticada (Furtado \& Lourenço Neto, 1993c e McMahon et al.,1993).

Tabela 12. Valores médios, em centímetros, da elasticidade dos queijos derretidos.

\begin{tabular}{ccccc}
\hline Dia & Testemunha & Tratamento 1 & Tratamento 2 & C.V. \\
\hline D +2 & $25,25^{\mathrm{a}}$ & $23,75^{\mathrm{a}}$ & $7,00^{\mathrm{b}}$ & 4,48 \\
$\mathrm{D}+12$ & $37,25^{\mathrm{a}}$ & $31,25^{\mathrm{a}}$ & $9,75^{\mathrm{b}}$ & 12,3 \\
$\mathrm{D}+22$ & $41,25^{\mathrm{a}}$ & $34,50^{\mathrm{a}}$ & $10,50^{\mathrm{b}}$ & 10,41 \\
\hline
\end{tabular}

Médias de quatro fabricações. Médias seguidas por letras distintas ${ }^{\text {ab,c }}$ diferem entre si, ao nível de $1 \%$ de significância. C.V.= Coeficiente de Variação.

Os queijos desse experimento foram analisados com até 3 semanas de armazenamento refrigerado a $8^{\circ} \mathrm{C}$. Portanto, nesse período de tempo a degradação da matriz protéica era desejável, pois aumentava a elasticidade da Mussarela derretida.

Essa informação justifica, em parte, o fato dos queijos do Tratamento 2 diferirem estatisticamente dos queijos dos demais tratamentos, nos peródos de análise (Tabela 12), uma vez que tais queijos apresentavam menor Aw (Tabela 6) e consequentemente menor proteólise (Choisy et al., 1986 e Lawrence et al., 1987). ( Tabelas 9 e 10) e menor elasticidade (Tabela 12). 
Deve-se considerar também, na análise desses resultados, que as massas do Tratamento 2 apresentavam problemas na filagem, o que conferia aos queijos uma estrutura ligeiramente diferente daquela verificada numa mussarela feita apenas com leite in natura e isso possivelmente prejudicou a elasticidade dos mesmos. Thompson (1978) observou, em seus experimentos com queijos Mussarela elaborados com o uso de leite recombinado, que o uso de um leite em pó que não fosse "baixa temperatura" resultava em uma massa de textura granulosa e com menor elasticidade.

\subsubsection{Liberação de óleo livre}

Estudos desenvolvidos por Kindstedt (1993b); Yun et al. (1993) e Yun et al. (1995a), sobre a separação de gordura, que ocorre no queijo Mussarela, quando derretido sobre a pizza, mostram que essa liberação de gordura tende a ser acentuada durante as duas primeiras semanas após a manufatura dos queijos. Após esse periodo, o aumento torna-se menos intenso, sendo que em queijos com cerca de três semanas de estocagem a porcentagem de "free oil" liberada é de cerca de 50\% do total da gordura do queijo. Essas informações, encontradas na literatura, são confirmadas pelos resultados mostrados na Tabela 13, para a Testemunha e para o Tratamento 1.

Tabela 13. Porcentagens médias do total de gordura dos queijos, dos diferentes tratamentos, presente como óleo livre.

\begin{tabular}{ccccc}
\hline Dia & Testemunha & Tratamento 1 & Tratamento 2 & C.V. \\
\hline D+2 & $31,52^{\mathrm{a}}$ & $22,36^{\mathrm{b}}$ & $14,99^{\mathrm{c}}$ & 4,75 \\
D+12 & $48,20^{\mathrm{a}}$ & $50,81^{\mathrm{a}}$ & $31,05^{\mathrm{b}}$ & 9,40 \\
D+22 & $51,91^{\mathrm{a}}$ & $52,84^{\mathrm{a}}$ & $32,20^{\mathrm{b}}$ & 9,40 \\
\hline
\end{tabular}

Médias de quatro fabricações. Médias seguidas por letras distintas ${ }^{\text {a,b,c }}$ diferem entre si, ao nível de $1 \%$ de significância. C.V.= Coeficiente de Variação. 
Esse aumento na quantidade de óleo liberado pelo queijo derretido, no decorrer do período de armazenamento refrigerado, verificado nos três tratamentos, é resultado da intensificação do processo de proteólise (Tabelas 9 e 10) no queijo. Quanto menos caseína intacta tem o queijo, maior a presença de grupos (peptídeos, aminoácidos, etc.) com cargas e mais fragmentada se torna a matriz protéica, o que explica o aumento na liberação de gordura durante o derretimento da Mussarela ( Furtado \& Lourenço Neto, 1997c e Kindstedt \& Rippe, 1990).

Os resultados obtidos para a Testemunha, nos dias $\mathrm{D}+2, \mathrm{D}+12$ e $\mathrm{D}+22$, e para o Tratamento 1, nos dias D+12 e D+22, foram semelhantes aos encontrados por Kindstedt (1993b), trabalhando com Mussarela sem o uso de leite em pó.

Kindstedt \& Rippe (1990), avaliando 22 marcas comerciais americanas de mussarela, 16 dias após a manufatura das mesmas, relataram que a porcentagem de óleo livre desses queijos, em relação a sua porcentagem de gordura, era em média de 52,4\%, ou seja, um valor próximo ao que seria obtido para a Testemunha e para o Tratamento 1 , caso tivéssem sido avaliados com esse período de estocagem.

Os resultados da Tabela 13 também demonstraram que os três tratamentos diferiram significativamente entre si, no segundo dia após a manufatura, quanto a porcentagem de gordura dos queijos liberada como óleo livre. Essas diferenças ocorreram como consequência dos teores mais elevados de sal (Kindstedt, 1992 e Shimp,1995), dos menores índices de proteólise(Furtado \& Lourenço Neto, 1997c) e dos teores mais reduzidos de gordura (Kindstedt, 1993a e Tunick et al., 1989) dos queijos elaborados com o uso de leite reconstituído (Tabela 6). 


\section{CONCLUSÕES}

A adição de 10 e $20 \%$ de leite reconstituído, ao leite in natura, não afetou as características físico-químicas de $\mathrm{pH}$, teor de gordura no extrato seco e teor de proteínas das mussarelas obtidas. Porém, houve um aumento significativo no teor de umidade dos queijos, com o uso de leite reconstituído.

Foi possível fabricar queijo Mussarela a partir de leite in natura adicionado de $10 \%$ de leite reconstituído e obter-se um produto com composição físico-química, fatiamento e propriedades funcionais de derretimento, elasticidade e liberação de óleo livre semelhantes as de um queijo Mussarela fabricado apenas com leite in natura.

A adição de $20 \%$ de leite reconstituído, ao leite in natura, na elaboração de Mussarelas, resultou em queijos de dificil fatiamento, além de prejudicar as propriedades de derretimento e elasticidade dos mesmos, prejudicando seu uso no preparo de pizzas comerciais.

Queijos elaborados com a adição de leite reconstituído, ao leite in natura, apresentaram um maior rendimento técnico e econômico. 


\section{REFERÊNCIAS BIBLIOGRAFICAS}

ALBUQUERQUE, L.C.; CARVALHO, F.A. Embalagens para leite e derivados. Leite \& Derivados, v.6, n.35, p.20-30, jul./ago. 1997.

AL-TAHIRI, R. Recombined and reconstituted milk products. New Zealand Journal of Dairy Science and Technology, v.22, n.1, p.1-23, 1987.

AMERICAN DRY MILK INSTITUTE. Standarts for grades of dry milk including methods of analysis. Chicago: American Dry Milk Institute, 1971. 1v. (Bulletin 916).

APOSTOLOPOULOS, C. Simple empirical and fundamental methods to determine objectively the stretchability of Mozzarella cheese. Journal of Dairy Research, n.61, p.405-413, 1994.

ARNOTT, D.R.; MORRIS, H.A.; COMBS, W.B. Effect of certain chemical factors on the melting quality of process cheese. Journal of Dairy Science, v.40, n.2, p.95763, 1957.

ASSOCIATION OF OFFICIAL ANALYTICAL CHEMISTS. Official methods of analysis. 15.ed. Washington, 1995. 109p. 
BANKS, J.M.; LAW, A.J.R.; LEAVER, J.; HORNE, D.S. The inclusion of whey proteins in cheese. In: INTERNATIONAL DAIRY FEDERATION. Cheese Yield \& Factors Affecting its Control. Cork, 1993. cap.8, p.387-401.

BEHMER, M.L.A. Tecnologia do leite. São Paulo: Nobel, $1984 . \quad$ p.196-97: Mozzarella.

BERTOLA, N.C.; CALIFANO, A. N.; BEVILACQUA, A.E.; ZARITZKY, N.E. Effect of freezing conditions on functional properties of low moisture Mozzarella cheese. Journal of Dairy Science, v.79, n.2, p.185-190, 1996.

BONASSI, I.A.; CARVALHO, J.B.C.; VILLARES, J.B. Utilização do leite de búfala como matéria-prima para elaboração do queijo Mussarela. Archivos Latinoamericanos de Nutrición, v.32, n.4, p.903-912, 1982. /Resumo 7402 em Dairy Science Abstracts, v.47, p.778-779, 1982/.

BRASIL. Leis e Decretos. Nova legislação de produtos lácteos e de alimentos para fins especiais, diet, light e enriquecidos. São Paulo: Fonte Comunicações e Editora, 1998. 212p.

BRASIL. Ministério da Agricultura. Regulamento da inspeção industrial e sanitária de produtos de origem animal. Brasília, 1976.

BREENE, W.M.; PRICE, W.V.; ERNSTROM, C.A. Manufacture of pizza cheese without starter. Journal of Dairy Science, v.47, n.2, p.1173-1180, 1964.

CHAPMAN, H.R. \& SHARPE, M.E. Dairy microbiology. London: Applied Sciences Publishers, 1981. p.157-243: Microbiology of cheese. 
CHEFTEL, J.C.; CUQ, J.L.; LORIENT, D. Proteínas alimentarias: bioquímicapropriedades funcionales-valor nutritivo-modificaciones químicas. Zaragoza: Acribia, 1989. cap.6, p.179-217: Las proteinas de la leche.

CHENG, L.J.; AUGUSTIN, M.A., MCKINNON, I.R.; SUTHERLAND, B.J. The effect of mineral salt addition on Mozzarella cheesemaking. Australian Journal of Dairy Technology, v.52, n.1, p.8-14, 1997.

CHERREY, G. Os leites reconstituídos para fabricação de queijos. Revista do Instituto de Laticínios Cândido Tostes, v.33, n.199, p.39-45, set./out. 1978.

CHOISY, C.; DESMAZEAUD, M.; GRIPON, J.C.; LAMBERET, G.; LENOIR, J. Microbiologycal and biochemical aspects of ripening. In: ECK, A. Cheesemakingscience and tecnology. New York: Lavoisier Publ., 1986. cap.4, p.62-100.

COPPOLA, S; VILLANI, F.; COPPOLA, R.; PARENTE, E. Comparison of different starter systems for water-buffalo Mozzarella cheese manufacture. Le Lait, v.68,n.3, p.295-310, 1988.

COVARRUBIAS, M.P.; ISRAEL, L.E.; VALDENEGRO, V. Desnaturação de proteínas do soro do leite por processos térmicos-UHT. Densitometria de géis de poliacrilamida. Revista do Instituto de Laticínios Cândido Tostes, v.43, n.258, p.15-20, 1988 .

DALGLEISH, D.G. The enzymatic coagulation of milk. In: FOX, P.F.(ed.) Cheese: chemistry, physics and microbiology. New York: Elsevier Applied Science Publ., 1987. cap.3, p.63-96. 
DEL PRATO, S. Italian Mozzarella. Dairy Industries International, v.58, n.4, p.2629, Apr. 1993.

DEMOTT, B.J. Recovery of milk constitutents in a Mozzarella-like product manufactured from nonfat dry milk and cream by direct acidification at 4 and $35^{\circ} \mathrm{C}$. Journal of Dairy Science, v.66, n.12, p.2501-2506, 1983.

DIANDA, M.A. Argentinian Mozzarella-physica-chemical characteristics. Industria Lechera, v.62, n.671, p.10-12, 1982. /Resumo 1264 em Dairy Science Abstracts, v.45, n.2, p. $150,1983 /$.

FARKEY,N.Y.; KIELY, L.J.; ALLSHOUSE, R.D.; KINDSTEDT, P.S. Proteolysis in Mozzarella cheese during refrigerated storage. Journal of Dairy Science, v.74, n.3, p.1433-1439, 1991.

FLANAGAN, J.F.; THOMPSON, M.P.; BROWER, D.P.; GYURICSEK, O.M. Manufacture of Mozzarella, Muenster and Cottage cheese from reconstituted nonfat powder. Cultured Dairy Products Journal, v.13, n.4, p.24-26, 1978.

FOX, P.F. Rennets and their action in cheese manufacture and ripening. Biotechnology and Applied Biochemistry, v.10, p.522-535, 1988.

FOX, P.F.; GUINEE, T.P. Italian Cheeses. In: FOX, P.F.(ed.) Cheese: chemistry, physics and microbiology. New York: Elsevier Applied Science Publ., 1987. v.2, cap.7, p.221-256.

FOX, P.F.; LAW, J. Enzymology of cheese ripening. Food Biotechnology, v.5, n.3, p.239-262, 1991. 
FURTADO, M.M. Fabricação de queijo de leite de cabra. São Paulo: Nobel, 1984. cap.3, p.37-48.

FURTADO, M.M. A Arte e a ciência do queijo. 2.ed. São Paulo: Globo, 1991. $297 \mathrm{p}$.

FURTADO, M.M. Manual prático da Mussarella (pizza cheese). Campinas: Master Graf, 1997a. 70p.

FURTADO, M.M. Mussarela: Uma abordagem prático-teórica. Leite \& Derivados, v.6, n.33, p.42-49, mar./abr. $1997 b$.

FURTADO, M.M. Mussarela: uma atualização tecnológica sobre suas características fundamentais. Valinhos: Chr. Hansen Ind. Com. Ltda, 1997c. 18p.

FURTADO, M.M. Controle de rendimento na fabricação de queijos. Valinhos: Chr. Hansen Ind. Com. Ltda, 1998a. 14p.

FURTADO, M.M. Manual prático dos principais defeitos de queijos. Valinhos: Chr. Hansen Ind. Com. Ltda, 1998b. 130p.

FURTADO, M.M.; LOURENÇO NETO, J.P.M. DVS: Uma excelente opção para os novos conceitos de fabricação do queijo Mussarela. Informativo Ha-la Biotec, v.6, n.36, 1996.

FURTADO, M.M.; LOURENÇO NETO, J.P.M. Mussarella: Um roteiro básico para a sua fabricação com o uso de DVS. Informativo Ha-La Biotec, v.7, n.37, jan.1997a. 
FURTADO, M.M.; LOURENÇO NETO, J.P.M. Mussarella: os novos padrões exigidos pelo Mercosul. Informativo Ha-La Biotec, v.7, n.39, maio.1997b.

FURTADO, M.M.; LOURENÇO NETO, J.P.M. Pizza cheese: um novo conceito para Mussarela. Indústria de Laticínios, v.2, n.8, p.44-47, maio 1997 c.

FURTADO, M.M.; PARTRIDGE, J.A. Characterization of nitrogen fractions during ripening of a soft cheese made from ultrafiltration retentates. Journal of Dairy Science, v.71, n.11, p.2877-2884, 1988.

GILLES, J. Feta cheese manufacture from skimmed milk powder and anydrous milk fat. In: INTERNATIONAL DAIRY CONGRESS,19., New Delhi, 1974.

GLLES, J.; LAWRENCE, R.C. Manufacture of cheese and others fermented products from recombined milk. New Zealand Journal of Dairy Science and Technology, v.16, n.1, p.1-12, 1981.

GILLES, J.; LAWRENCE, R.C.; CZULAK, J.; CONOCHIE, J.; HAMMOND, L.A. Recombined cheese. Bulletin International Dairy Federation, n.116, p.33-42, 1979.

GRAPPIN, R.; RANK, T.C.; OLSON, N.F. Primary proteolysis of cheese proteins during ripening. Journal of Dairy Science, v.68, n.3, p.531-540, 1985.

GRIPON, J.C.; DESMAZEAUD, M.J.; LE BARS, D.; BERGERE, J.L. Étude du rôle des micro-organismes et des enzymes au cours de la maturation des fromages. II Influence de la pressure commerciale. Le Lait, v.55, n.548, p.502-515, 1975. 
GUINEE, T.P.; FOX, P.F. Salt in cheese: physical, chemical and biological aspects. In: FOX, P.F.(ed.) Cheese: chemistry, physics and microbiology. New York: Elsevier Applied Science Publ., 1987. v.2, cap.7, p.251-298.

GUTIERREZ, L.E. Aminoácidos e proteínas. Piracicaba: ESALQ/ Departamento de Química, 1991.66p.

HAMMOMD, L.A. Fermented products from recombined milk. Specialist courses for the food industry. Seminar on recombined dairy products. n.3, p. 58-64, 1972.

HARLAND, H.A.; ASHWORTH, U.S. A rapid method for estimation of whey proteins as an indication of baking quality of non fat dry-milk solids. Food Research, v.12, p.247-251, 1947.

HILL, A.R.; BULLOCK, D.H.; IRVINE, D.M. Manufacturing parameters of Queso Blanco made from milk and recombined milk. Canadian Institute of Food Science and Technology Journal, v.1, n.15, p.47-53, 1982.

HODGE, J.E; OSMAN, E.M. Carbohydrates sugar-amine reactions. In: FENEMA, O.R.(ed.). Principles of food science. New YorK: Marcel Dekker, 1976. Cap.1, p.83-85.

HOOYDONK, A.C.M.; KOSTER, P.G.; BOERRIGTER, I.J. The renneting properties of heated milK. Netherlands Milk and Dairy Journal, v.41, n.1, p.3-18, 1987.

INTERNATIONAL DAIRY FEDERATION. Determination of the total nitrogen content of milk by Kjeldahl method. FIL-IDF, n.20, p.1-3, 1962. 
JANA, A.H. Mozzarella cheese: A review. Indian Journal of Dairy Science, v.44, n.2, p.167-175, Apr.1991.

JANA, A.H.; THAKAR, P.N. Recombined milk cheese- a review. The Australian Journal of Dairy Technology, v.51, p.33-43, 1996.

JOHNSON, M.E.; OLSON, F. Nonenzymatic browning of Mozzarella cheese. Journal of Dairy Science, v.68, n.5, p.3143-3147, 1985.

KELLER, B.; OLSON, N.F.; RICHARDSON, T. Mineral retention and rheological properties of Mozzarella cheese made by direct acidification. Journal of Dairy Science, v.57, n.1, p.174-180, 1974.

KIM, Y.H.; YU, J.H. A study on the manufacture of pizza cheese by D.A.C.A.(direct acidification continuous agitation) procedure. Korean Journal of Dairy Science, v.10, n.1, p.21-33, 1988.

KINDSTEDT, P.S. Functional properties of Mozzarella cheese on pizza: A review. Cultured Dairy Products Journal, v.26, n.3, p.27-31, Aug. 1991.

KINDSTEDT, P.S. Effect of manufacturing factors, composition, and proteolysis on the functional characteristics of Mozzarella cheese. Critical Reviews in Food Science and Nutrition, v.33, n.2, p.167-187, 1993a.

KINDSTEDT, P.S. Mozzarella and pizza cheese. In: FOX, P.F. Cheese: chemistry,physics and microbiology. London: Elsevier Applied Publ. Science, 1993b. 
KINDSTEDT, P.S.; FOX, P.F. Modified Gerber test for free oil in melted Mozzarella cheese. Journal of Dairy Science, v.56, n.4, p.1115-1116, Jul./Aug.1991.

KINDSTEDT, P.S.; RIPPE, J.K. Rapid quantitative test for free oil (oiling off) in melted Mozzarella cheese. Journal of Dairy Science, v.73, n.4, p.867-873, 1990.

KINDSTEDT, P.S.; KIELY, L.J.; GILMORE, J.A. Variation in composition and functional properties within brine-salted Mozzarella cheese. Journal of Dairy Science, v.75, n.11, p.2913-2921, 1992.

KINDSTEDT, P.S.; RIPPE, J.K.; DUTHIE, C.M. Application of helical viscometry to study commercial Mozzarella cheese melting properties. Journal of Dairy Science, v.72, n.12, p.3123-3128, Dec.1989a.

KINDSTEDT, P.S.; RIPPE, J.K.; DUTHIE, C.M. Measuremente of Mozzarella cheese melting properties by helical viscometry. Journal of Dairy Science, v.72, n.12, p.3117-3122, Dec. 1989b.

KNIPSCHILDT, M.E. Production of milk powder suitable for cheese manufacture and other specific purposes. Danish Dairy Industry, p.47-48, 1976.

KOSIKOWSKI, F. Problems in the italian soft cheese industry. Journal of Dairy Science, v.41, n.3, p.455-458, Mar. 1958.

KOSIKOWSKI, F. Cheese and fermented milk foods. New York: Cornell University, 1970. cap.10, p.153-67: Soft, uncured Italian cheese. 
LANARA (Laboratório Nacional de Referência Animal). Métodos analíticos oficiais para controle de produtos de origem animal e seus ingredientes. Brasília, 1981. lv.

LARSON, W.A; OLSON, N.F.; ERNSTROM, C.A.; BREENE, W.M. Cyrd-forminf techniques for making pizza cheese by direct acidification procedures. Journal of Dairy Science, v.50, n.10, p.1711-1712, Oct. 1967.

LAWRENCE, R.C.; CREAMER, L.K.; GILLES, J. Texture developmente during cheese ripening. Journal of Dairy Science, v.70, n.3, p.1748-1760, 1987.

LEAKE, A.S.; NILSON, K.M. Factors affecting salting and cooling of Mozzarella cheese. Journal of Dairy Science, v.52, n.2, p.278, Feb. 1969a. / Apresentado ao 63. Annual Meeting of the American Dairy Science Association, Burlington, 1968 Resumo/.

LEAKE, A.S.; NILSON, K.M. Fortification of part-skim milk for the manufacture of mozzarella cheese. Journal of Dairy Science, v.52, n.2, p.278, Feb. 1969b. / Apresentado ao 63. Annual Meeting of the American Dairy Science Association, Burlington, 1968 - Resumo/.

LEE, H.J.; OLSON, F.; LUND, D.B. Diffusion of salt, fatty acids, and esterases in Mozzarella cheese. Journal of Dairy Science, v.63, n.4, p.513-522, 1980.

LELIEVRE, J.; SHAKER, R.R.; TAYLOR, M.W. The role of homogenization in the manufacture of Halloumi and Mozzarella cheese from recombined milk. Journal of the Society of Dairy Technology, v.43, n.1, p.21-24, 1990. 
MARCOS, A.; ALCALA, M.; LEON, F.; FERNANDEZ-SALGUEIRO, J.; ESTEBAN, M.A Water activity and chemical composition of cheese. Indian Journal of Dairy Science, v.64, n.4, p.622-626, 1981.

MCMAHON, D.J.; OBERG, C.J.; MCMANUS,W. Functionality of Mozzarella cheese. The Australian Journal of Dairy Technology, v.48, n.2, p.99-104, Nov.1993.

MENDES, A.C.R. O valor nutricional do queijo: Composição química, aspectos sensoriais e dietéticos de interesse para o consumidor. Leite \& Derivados, v.6, n.34, p.54-61, 1997.

MICKETTS, R.; OLSON, N.F. Manufacture of Mozzarella cheese by direct acidification with reduced amounts of rennet and pepsin. Journal of Dairy Science, v.57, n.3, p.273-279, 1974.

MIETTON, B. Use of conventional process for the manufacture of recombined cheese. International Dairy Federation. Special Issue. n.9001, p.275-278, 1988.

MORR, C.V. Effect of heat upon size and composition of proteins sedimented from normal and concentrated skim milk. Journal of Dairy Science, v.48, n.1, p.29-33, 1965.

MOSTAFA, M.B.M; SHAHEIN, N.M; ABDEL-KADER, Y.I.; EL-ZOGHBY, A.J. Properties of Mozzarella cheese as affected by milk types. Egyptian Journal of Dairy Science, v.24, n.2, p.289-296, 1996. /Resumo em FSTA on CD-ROM, 1990$1997 /$. 
NEWLANDER, J.A; ATHERTON, H.V. Babcock, Gerber, Monjonier tests for fat. In: The chemistry and testing of dairy products. Milwaukee: Olsen Publ., 1964, cap.4, p.67-114.

NILSON, K.M.; LACLAIR, F.A. A national survey of the quality of Mozzarella cheese. American Dairy Review, v.38, n.10, p.18A-H, Oct.1976.

NOTTE, E. la; SANTORO, M.; LEONE, A.M.; VITAGLIANO, M. Behaviour of free amino acids during ripening of pasta filada cheeses. Scienza e Tecnica Lattiero Casearia, v.31, n.1, p.19-39, 1980. / Resumo em FSTA on CD-ROM, 1969-1990/.

OBERG, C.J.; MERRILL, R.K.; MOYES, L.V.; BROWN, R. J.; RICHARDSON, G.H. Effects of Lactobacillus helveticus culture on physical properties of mozzarella cheese. Journal of Dairy Science, v.74, n.12, p.4101-4107, 1991a.

OBERG, C.J.; WANG, A.; MOYES, L.V.; BROWN, R. J.; RICHARDSON, G.H. Effects of proteolytic activity of thermolactic cultures on physical properties of Mozzarella cheese. Journal of Dairy Science, v.74, n.2, p.389-397, 1991b

OLIVEIRA, A.J.de ; CARUSO, J.G.B. Leite: obtenção e qualidade do produto fluído e derivados. Piracicaba: FEALQ, 1996. cap.5, p.45-78: Derivados do leite.

OLIVEIRA, J S. Queijo: fundamentos tecnológicos. São Paulo: Secretaria da Indústria, Comércio, Ciência e Tecnologia, 1982. 233p.

PAQUET, A.; KALAB, M. Amino acid composition and structure of cheese baked as a pizza ingredient in conventional and microwave ovens. Food microstructure, v.7, n.1, p.93-103, 1988. / Resumo em FSTA on CD-ROM, 1969-1990/. 
PARK, J.; ROSENAU, J.R.; PELEG, M. Comparison of four procedures of cheese meltability evaluation. Journal of Food Science, v.49, n.4, p.1158-1163, Jul./Aug. 1984.

PEARSE, M.J.; MACKINLAY, A.G. Biochemical aspects of syneresis: A review. Journal of Dairy Science, v.72, n.6, p.1401-1407, June 1989.

PEARSE, M.J.; LINKLATER, P.M.; HALL, R.J. ; MACKINLAY, A. G. Effect of heat induced interation between $\beta$-lactoglobulin and K-casein on syneresis. Journal of Dairy Research, v.52, n.1, p.159-165, 1985.

PEREIRA, J.F. Análises bromatológicas. Juiz de Fora: Universidade Federal de Juiz de Fora, 1975. 97p.

PIMENTEL-GOMES, F. Curso de estatística experimental. São Paulo: Nobel, 1985. $466 \mathrm{p}$.

PRIMO, W.M. Entressafra no Brasil: meio século de drama. Indústria de Laticínios, v.1, n.2, p.12-14, mai.jun. 1996.

PRODUCTION hygiene of cheeses to be consumed fresh, such as Mozzarelle, Fior di Latte and Ovoline. Mondo del Latte, v.31, n.1, p.18-19, 1997. /Resumo 4379 em Dairy Science Abstracts, v.39, p.505, 1977/.

QUARNE, E.L.; LARSON, W.A.; OLSON, N.F. Effects of acidulants and milk-clotting enzymes on yield, sensory quality, and proteolysis of pizza cheese by direct acidification. Journal of Dairy Science, v.51, n.1, p.848-852, 1968. 
RADKE, W.O; NILSON, K.M.; ATHERTON, H.V.; DUTHIE, A.H. The manufacture of Mozzarella cheese from precutured milk. Journal of Dairy Science, v.62, n.4, p.48, 1979. / Apresentado ao 74. Annual Meeting of the American Dairy Science Association, Utah, 1979 - Resumo/.

RANAS OLIVEROS, M.C.; DULAY, T.A. Studies on cheese manufactured from partly reconstituted skim milk powder. 1. The quality of soft cheese prepared from cow's milk with two levels of reconstituted skim milk powder. Philippine Journal of Veterinary and Animal Sciences, v.8, n.3/4, p.77-82, 1982.

RIPPE, J.K.; KINDSTEDT, P.S. Preliminary evaluation of objective methods for measuring rheological properties of melted Mozzarella cheese. Journal of Dairy Science, v.71, n.5, p.69, 1988. /Apresentado ao 83. Annual Meeting of the American Dairy Science Association, Champaign, 1988 - Resumo/.

ROITMAM, I.; TRAVASSOS, L.R.; AZEVEDO, J.L. Tratado de microbiologia. São Paulo: Manole, 1987. Cap.3, p.105-180: Microbiologia industrial.

ROSSI, G. Manuali di tecnologia casearia. Bologna: Agricole, 1977. 684p.

SABOYA, L.V. Adição de leite reconstituído na fabricação de queijo Minas Frescal. São Paulo, 1997. 83p. Tese (Mestrado) - Escola Superior de Agricultura "Luiz de Queiroz", Universidade de São Paulo.

SANDERSON, W.B. Dairy products. Bulletin International Dairy Federation, n.116, p.40-42, 1979.

SANTOS, J. A. A Mussarela que acaba em pizza. Indústria de Laticínios, v.2, n.8, p.42-43, maio 1997. 
SAVAGE, A. A.; MULLAN, W.M.A. Quality perceptions and expectations of Mozzarella cheese producers and pizza manufacturers. Milchwissenschaft, v.51, n. 12, p.677-679, 1996.

SCHIFTAN, T.Z;; KOMATSU, I. Estudo sobre a composição de queijo Mussarela consumido na cidade de São Paulo. Revista do Instituto de Laticínios Cândido Tostes, v.34, n.205, p.29-34, 1979.

SCHMIDT, D.G. Colloidal aspects of casein. Netherlands Milk and Dairy Journal, v.34, n. 1, p.42-64, 1980.

SEMINÁRIO INTERNACIONAL SOBRE PIZZA CHEESE, Juiz de Fora, 1997. Valinhos: Chr. Hansen Ind. Com. Ltda, 1997.

SGHEDONI, A; RETTI, C.; SOUZA, G.P. Fabricação de Mussarela. Revista do Instituto de Laticínios Cândido Tostes, v.34, n.204, p.1-48, 1979.

SHEHATA, A.E.; YER, M.; OLSON, N.F.; RICHARDSON, T. Effect of type of acid used in direct acidification procedures on moisture firmness and calcium levels of cheese. Journal of Dairy Science, v.50, n.6, p.824-827, 1967.

SHIMP, L.A. Process cheese principles. Food Technology, v.39, n.5, p.63-70, May 1995.

SIAPANTAS, L. Effect of milk reconstitution, ultrafiltration and cheese processing in the manufacturing cost of Feta cheese. In: BIENNIAL MARSCHALL INTERNATIONAL CHEESE CONFERENCE, 1., 1981. Proceedings. p.617-628. 
SILVA, P.H.F.; PEREIRA, D.B.C.; OLIVEIRA, L.L.;COSTA JR, L.C.G.C. Físicoquímica de leite e derivados- Métodos Analíticos. Juiz de Fora: Oficina de Impressão Gráfica e Editora Ltda, 1997. 190p.

SOUZA, G.de. Queijo Mussarela. Casa da Agricultura, v.7, n.1, p.8-9, jan./fev. 1985.

THOMPSON, M.P. Mozzarella cheese made with nonfat dry milk. Food Engineering, v.3, n.7, p.25, Jul.1978.

TORRES, C.L. Por que o brasileiro consome pouco lácteos?. Indústria de Laticínios, v.1, n.2, p.24-29, maio/jun. 1996.

TUNICK, M.H. Effects of homogenization and proteolysis on free oil in Mozzarella cheese. Journal of Dairy Science, v.77, n.9, p.2487-2493, 1994.

TUNICK, M.H.; MACKEY, K.L.; SMITH, P.W.; HOLSINGER, V.H. Effects of composition and storage on the texture of Mozzarella cheese. Netherlands Milk \& Dairy Journal, v.45, n.2, p.117-125, 1991.

TUNICK, M.J.; BASCH, J.J.; MALEEFF, B.E.; FLANAGAN, J.F.; HOLSINGER, V.H. Characterization of natural and imitation Mozzarella cheese by differential scanning colorimetry. Journal of Dairy Science, v.72, n.8, p.1976-1980, 1989.

TURNER, K.W.; MARTLEY, F.G. Galactose fermentation and classification of thermophilic lactobacilli. Applied and Environmental Microbiology, v.45, n.6, p.1932-1934, June 1983.

VAKALERIS, D.G.; PRICE, W.V. A rapid spectrophotometric method for measuring cheese ripening. Journal of Dairy Science, v.42, p.264-276, 1959. 
VALLE, J.L E.do. Influência de parâmetros físico-químicos na fermentação e filagem do queijo tipo Mussarela. São Paulo, 1991. 88p. Tese (Doutorado) - Faculdade de Ciências Farmacêuticas, Universidade de São Paulo.

VAN DEN BERG, M.G.; VAN DEN BERG, G.; VAN BOEKEL, V.D.B.G. Mass transfer process involed in Gouda cheese manufacture, in relation to casein and yield. Netherlands Milk and Dairy Journal, v.50, p.501-540, 1996.

VIEIRA, S.D.A. Fabricação de queijo a partir de leite em pó e gordura anidra através de ultrafiltração. Revista do Instituto de Laticínios Cândido Tostes, v.14, n.201, p.31-41, jan./fev. 1979.

VIEIRA, S.D.A. Leite em pó como alternativa tecnológica na regularização do abastecimento no mercado de laticínios. Revista do Instituto de Laticínios Cândido Tostes, v.36, n.217, p.29-33, set./out. 1981.

VIEIRA, S.D.A.; NEVES, B.S. Adição de leite reconstituído na fabricação de queijo tipo Prato. Revista do Instituto de Laticínios Cândido Tostes, v.35, n.212, p.1925, nov./dez. 1980.

VIEIRA, S.D.A; NEVES, R.S.; NEVES, B.S. Técnicas de reconstituição e recombinação de leite em pó. Juiz de Fora: EPAMIG, 1982. 9p.

WENDORFF, B. Effect of standardization on characteristics of Mozzarella cheese. In: THE CHEESE SHOW 1996. Maximizing cheese yield. Wisconsin: Wisconsin Cheese Makers Association, 1996. p.39-45.

WOLFSCHOON-POMBO, A.F. Índices de proteólise em alguns queijos brasileiros. Boletim do Leite, v.55, n.661, p.1-8, nov. 1983. 
WOLFSCHOON-POMBO, A.F. Considerações a respeito da fervura doméstica do leite. Informe Agropecuário, v.10, n.115, p.48-52, 1984.

WOLFSCHOON-POMBO, A.F.; LIMA, A. de. Extensão e profundidade de proteólise em queijo Minas Frescal. Revista do Instituto de Laticínios Cândido Tostes, v.44, n.261, p.50-54, 1989.

WOLFSCHOON-POMBO, A.F.; FERNANDES, R.M.; GRANZINOLLI, G.G.M. Efeitos da pasteurização-HTST e da fervura doméstica sobre a proteína do leite. Revista do Instituto de Laticínios Cândido Tostes, v.37, n.223, p.3-7, 1982.

YUN, J.J.; BARBANO, D.M.; KIELY, L.J.; KINSTEDT, P.S. Mozzarella cheese: impact of cooking temperature on chemical composition, proteolysis and. functional properties. Journal of Dairy Science, v.76, n.12, p.3664-3673, 1993.

YUN, J.J.; BARBANO, D.M.; KIELY, L.J.; KINSTEDT, P.S. Mozzarella cheese: impact of rod:coccus ratio on composition, proteolysis and functional properties. Journal of Dairy Science, v.78, n.4, p.751-760, 1995a.

YUN, J.J.; BARBANO, D.M.; LARASE, K.L.; KINSTEDT, P.S. Mozzarella cheese: impact of whey $\mathrm{pH}$ at draining on chemical composition, proteolysis and. functional properties. Journal of Dairy Science, v.78, n.1, p.1-7, 1995 b.

YUN, J.J.; BARBANO, D.M.; RASMUSSEN, D.R.; KINSTEDT, P.S. Impact of rod to coccus ratio on chemical composition, proteolysis and texture of Mozzarella cheese. Journal of Dairy Science, v.75, n.6, p.101, 1992. / Apresentado ao 87. Annual Meeting of the Americam Dairy Science Association, Champaign, 1992 - Resumo/. 
ZOON, P. Incorporation of whey proteins into Dutch-type cheese. In: INTERNATIONAL DAIRY FEDERATION. Cheese yield \& factors affecting its control. Cork, 1993. cap.8, p.403-409.

ZURAW, J.; QUIST, K.B.; MADSEN, J.S.; BRAUN, H.; JENSEN, G.K. Manufacture of Danbo cheese from reconstituted low heat skim milk powder and fresh cream. Beretning-fra-Statens-Majeriforsog, n.265, p.1-27, 1985. 